\title{
The Role of Mechanical Stresses in Angiogenesis
}

\author{
Yan-Ting Shiu, ${ }^{1}$ Jeffrey A. Weiss, ${ }^{1}$ James B. Hoying, ${ }^{2}$ \\ Mattherw N. Irwamoto, ${ }^{1}$ In Suk Joung, ${ }^{1}{ }^{\circ}$ Cole T. Quam ${ }^{1}$
}

${ }^{1}$ Department of Bioengineering, University of Utah, Salt Lake City, Utah, USA;

${ }^{2}$ Regenerative Medicine Program, BIO5 Institute, University of Arizona, Tucson, Arizona, USA

Address all correspondence to Yan-Ting Shiu, Department of Bioengineering, University of Utah, 20 South 2030 East, BPRB Room 506, Salt Lake City, UT 84112; yshiu@eng.utah.edu

\begin{abstract}
Angiogenesis is the formation of new capillary blood vessels from preexisting vessels. It is involved in many normal and diseased conditions, as well as in the application of tissue-engineered products. There has been extensive effort made to develop strategies for controlling pathological angiogenesis and for promoting vascularization in biomedical engineering applications. Central to advancing these strategies is a mechanistic understanding of the angiogenic process. Angiogenesis is tightly regulated by local tissue environmental factors, including soluble molecules, extracellular matrices, cell-cell interactions, and diverse mechanical forces. Great advances have been made in identifying the biochemical factors and intracellular signaling pathways that mediate the control of angiogenesis. This review focuses on work that explores the biophysical aspect of angiogenesis regulation. Specifically, we discuss the role of cell-generated forces, counterforces from the extracellular matrix, and mechanical forces associated with blood flow and extravascular tissue activity in the regulation of angiogenesis. Because angiogenesis occurs in a mechanically dynamic environment, future investigations should aim at understanding how cells integrate chemical and mechanical signals so that a rational approach to controlling angiogenesis will become possible. In this regard, computational models that incorporate multiple epigenetic factors to predict capillary patterning will be useful.
\end{abstract}

KEYWORDS: capillary morphogenesis, endothelial cells, extracellular matrix, blood flow, muscle contraction, mechanotransduction

\section{INTRODUCTION}

Angiogenesis refers to the formation of new capillary blood vessels from preexisting capillaries (or venules) in the embryo and adult organism. It occurs infrequently in 
healthy adults, except during ovulation, pregnancy, wound healing, and exercise training. ${ }^{1-6}$ Because of the fundamental role of angiogenesis in a large number of different and unrelated diseases and in several bioengineering applications, angiogenesis has become a focus of attention for many scientists from various fields. ${ }^{3-5,7,8}$ For example, the aggressive outgrowth of blood vessels is involved in cancer, atherosclerosis, chronic inflammation, and diabetic retinopathy, whereas insufficient blood vessel formation is associated with scarring following myocardial infarction and chronic wound healing failure. ${ }^{3-5,7}$ In the field of bioengineering, the performance of implanted sensors, drug-delivery systems, and engineered tissues is limited by inadequate transport between them and blood vessels. ${ }^{8,9}$ Promoting vascular growth toward or within these products is a key element to their success. Thus, there has been extensive effort made to develop strategies for controlling pathological angiogenesis and for promoting vascularization in biomedical engineering applications.

Angiogenesis is tightly regulated by several microenvironmental factors in the blood vessel, including soluble molecules (e.g., growth factors and cytokines), extracellular matrices (ECM), interactions between adjacent endothelial cells (ECs) and ECs with other cell types, as well as mechanical forces originating from ECs themselves, blood flow, and extravascular tissue activity (Fig. 1).,10,11 While enormous strides have been made toward understanding the biochemical aspect of angiogenesis regulation, the same level of understanding does not exist for the mechanical contributions. There is, however, a rise of interest in understanding the role of mechanical forces in angiogenesis, in part owing to the ever-growing recognition that the mechanical environment of cells affects many aspects of their physiology and pathology. ${ }^{12}$

Although there are several comprehensive reviews on various aspects of angiogenesis, very few have focused on the role of the intrinsic forces generated by cells and the extrinsic forces applied on cells in angiogenesis regulation. The intention of this critical review is to fill this gap and stimulate interest in this exciting area of research.

The specific objectives of this review are as follows:

1. to provide an overview of the structure and function of blood vessels, with a focus on capillaries and ECs.

2. to describe the steps that are involved in the formation of blood vessels.

3. to provide an overview of assays that are commonly used for investigating angiogenic mechanisms.

4. to describe the role of endogenous biochemical factors in the regulation of angiogenesis. 


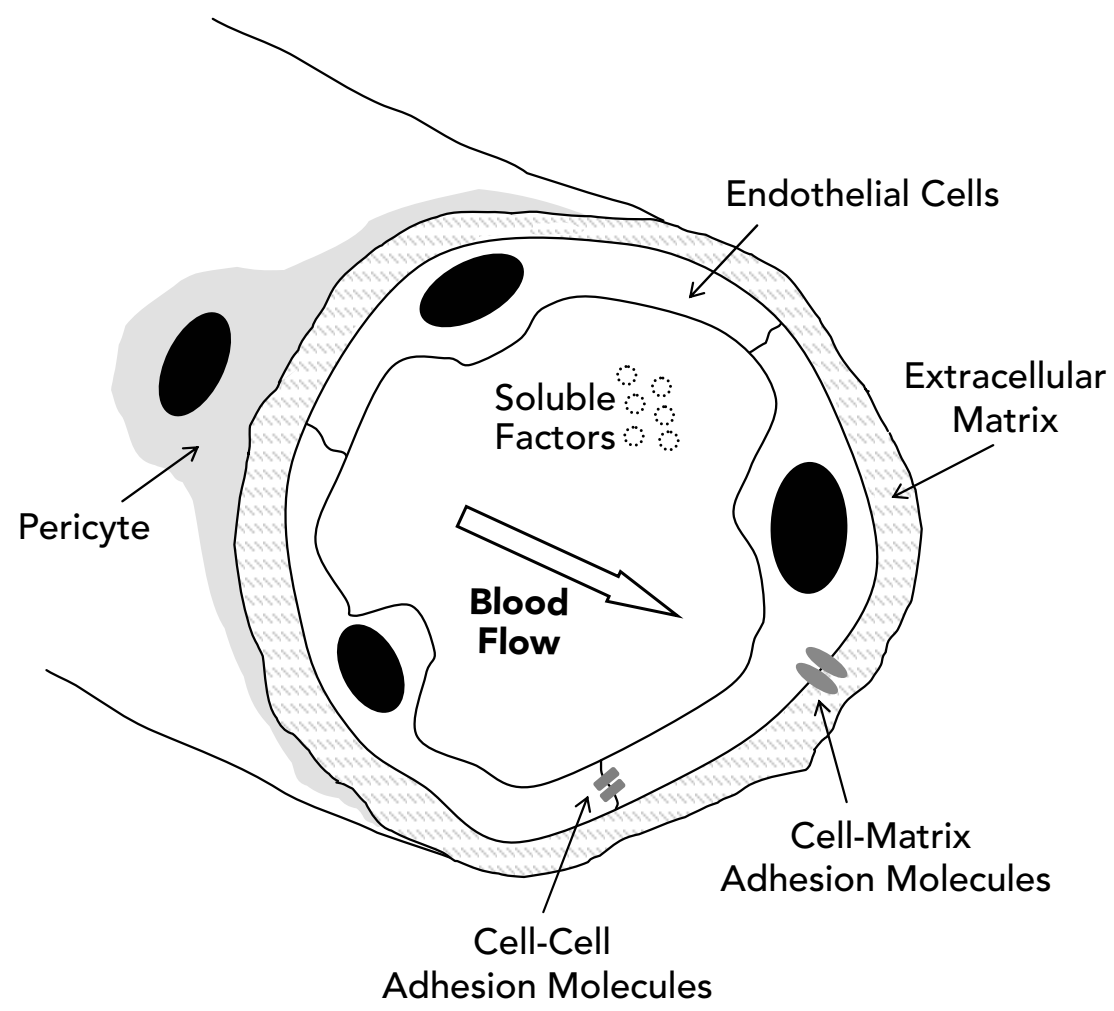

FIGURE 1. Microenvironmental cues that can affect angiogenesis include soluble factors (e.g., growth factors and cytokines), extracellular matrix molecules, as well as cell-cell and cell-matrix interactions via adhesion molecules. ${ }^{2}$ Cell-generated forces and mechanical forces associated with blood flow (shown here) and extravascular tissue activity also play a role in the regulation of angiogenesis. ${ }^{10,11}$

5. To describe the three critical elements that define the mechanical environment of ECs in vivo: self-generated forces, counterforces from the ECM, and externally applied forces resulting from common physiological processes in the body. The effects of these diverse forces on angiogenesis are considered.

6. To describe computational models that integrate multiple epigenetic factors to predict capillary patterning.

\section{STRUCTURE AND FUNCTION OF VASCULAR SYSTEM}

The fundamental function of the vascular system is to deliver oxygen and nutrients to and remove waste from peripheral tissues. ${ }^{13,14}$ There are three main types of 


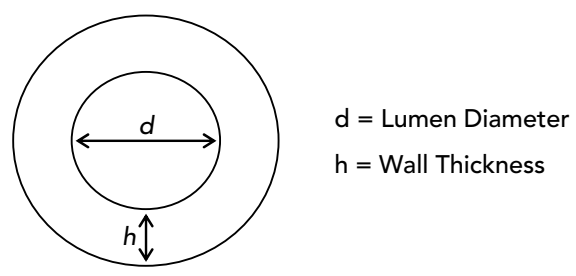

\begin{tabular}{|c|c|c|c|c|c|c|c|}
\hline Name of Vessel & Aorta & Artery & Arteriole & Capillary & Venule & Vein & Vena Cava \\
\hline Number of Vessel & 1 & $100 *$ & $10^{8 *}$ & $10^{10 *}$ & $10^{9 *}$ & $100 *$ & 2 \\
\hline $\begin{array}{l}\text { Lumen Diameter } \\
\qquad(\mathrm{mm})\end{array}$ & 25 & 4 & 0.03 & 0.008 & 0.02 & 5 & 30 \\
\hline $\begin{array}{l}\text { Wall Thickness } \\
\qquad(\mathrm{mm})\end{array}$ & 2 & 1 & 0.02 & 0.001 & 0.002 & 0.5 & 1.5 \\
\hline \multicolumn{8}{|l|}{ Wall Composition } \\
\hline $\begin{array}{r}\text { Endothelium } \\
\text { Elastic Tissue } \\
\text { Smooth Muscle } \\
\text { Fibrous Tissue }\end{array}$ & $\lim _{\infty}$ & $\begin{array}{l}p \\
\text { manm } \\
\end{array}$ & $\begin{array}{l}0 \\
\infty \\
5 \\
5\end{array}$ & $p$ & $p$ & $\lim _{\infty}$ & $\lim _{\infty}^{\infty}$ \\
\hline
\end{tabular}

FIGURE 2. Comparison between different types of blood vessels. *: Approximate numbers. (Adapted from Berne RM, Levy MN, editors. Physiology. 4 ed. St. Louis, MO: Mosby, 1998, ${ }^{14}$ with permission of Elsevier; and Moffett et al. Human Physiology: Foundations and Frontiers. 2 ed. Dubuque, IO: WCB Publishers, 1993, ${ }^{13}$ with permission of McGraw-Hill.)

blood vessels: arteries, veins, and capillaries. All blood vessels except capillaries have three distinct layers surrounding a central blood carrying lumen (Fig. 2). ${ }^{13,14}$ The outermost layer, called tunica adventitia, is a zone of connective tissue composed of collagenous and elastic fibers that enable the vessel to stretch and recoil. The middle layer, called tunica media, is made of alternating layers of elastic fibers and smooth muscle cells (SMCs). This layer is especially thick in the arteries, which must be strong and elastic to sustain the large, pulsatile pressures caused by the intermittent blood outflow from the heart. The innermost layer, called tunica intima, is lined with a continuous monolayer of ECs, whose luminal surface is decorated with a filamentous, carbohydrate-rich coating called the glycocaly ${ }^{15-17}$; the abluminal surface is supported by a basement membrane that is composed mainly of laminin, type IV collagen, and proteoglycans. ${ }^{18-22}$ Capillaries lack the structured outer layers and consist only of the endothelium and a single layer of perivascular cells. The capillary basement membrane is covered with pericytes, which are slender, undifferentiated mesenchymal cells providing structural support and paracrine signals 
to the capillary (Fig. 1). ${ }^{23}$ Pericytes distribute sparsely on capillaries and are most abundant on venules. ${ }^{23}$

Microcirculation refers to the flow of blood between arterioles and venules through capillaries (F1g. 3A). The capillaries arising from a single arteriole typically form an interconnecting network, called a capillary bed, to serve a discrete area of tissue. ${ }^{13,14}$ The average velocity of blood flow in the capillaries is approximately $1 \mathrm{~mm} / \mathrm{sec}$, but it can vary from several millimeters per second in the same vessel within a brief period. Because blood flow through the capillaries provides for exchange of gases and solutes between blood and tissue, it has been called nutritional flow. ${ }^{13,14}$

The capillaries of most organs have closely joined ECs whose intercellular junctions regulate the passage of molecules across the blood vessel wall (Fig. 3B). Interendothelial junctions consist of adherens junctions, tight junctions, and gap junctions; the first two are the most important in regulating vascular permeability. ${ }^{24-27}$ The organization of cell-cell junctions requires adhesion molecules such as cadherins and occludins in adherens and tight junctions, respectively. The extracellular domains of cadherins and occludins on an EC bind to those on an adjacent EC (homotypic interactions), while their cytoplasmic domains are linked to the cytoskeleton via linker proteins. The distance between plasma membranes at adherens junctions is about $20 \mathrm{~nm}$, whereas there are essentially no gaps at tight junctions. ${ }^{25,26,28,29} \mathrm{Tight}$ junctions are the prevailing junctional structures in brain capillaries, which form a blood-brain barrier and are less permeable to plasma substances than capillaries in other organs where adherens junctions are prominent. Vascular endothelial-cadherin (VE-cadherin or cadherin-5) is the major component at adherens junctions between ECs. ${ }^{25,27}$ This is discussed further in Section V.

\section{FORMATION OF VASCULAR SYSTEM}

Blood vessels are constructed by two processes: vasculogenesis, whereby a primitive vascular network is established during embryogenesis from EC precursors; and angiogenesis, in which preexisting vessels (both in embryo and adult) give rise to new vessels through intussusception and sprouting mechanisms. ${ }^{1,2,30} \mathrm{EC}$ s are the major cellular players in both of the angiogenic mechanisms.

\section{III.A. Vasculogenesis}

The first blood vessels in an embryo consist only of ECs, whose precursors originate from the mesoderm. ${ }^{1,2}$ A subset of mesodermal stem cells called hemangioblasts 

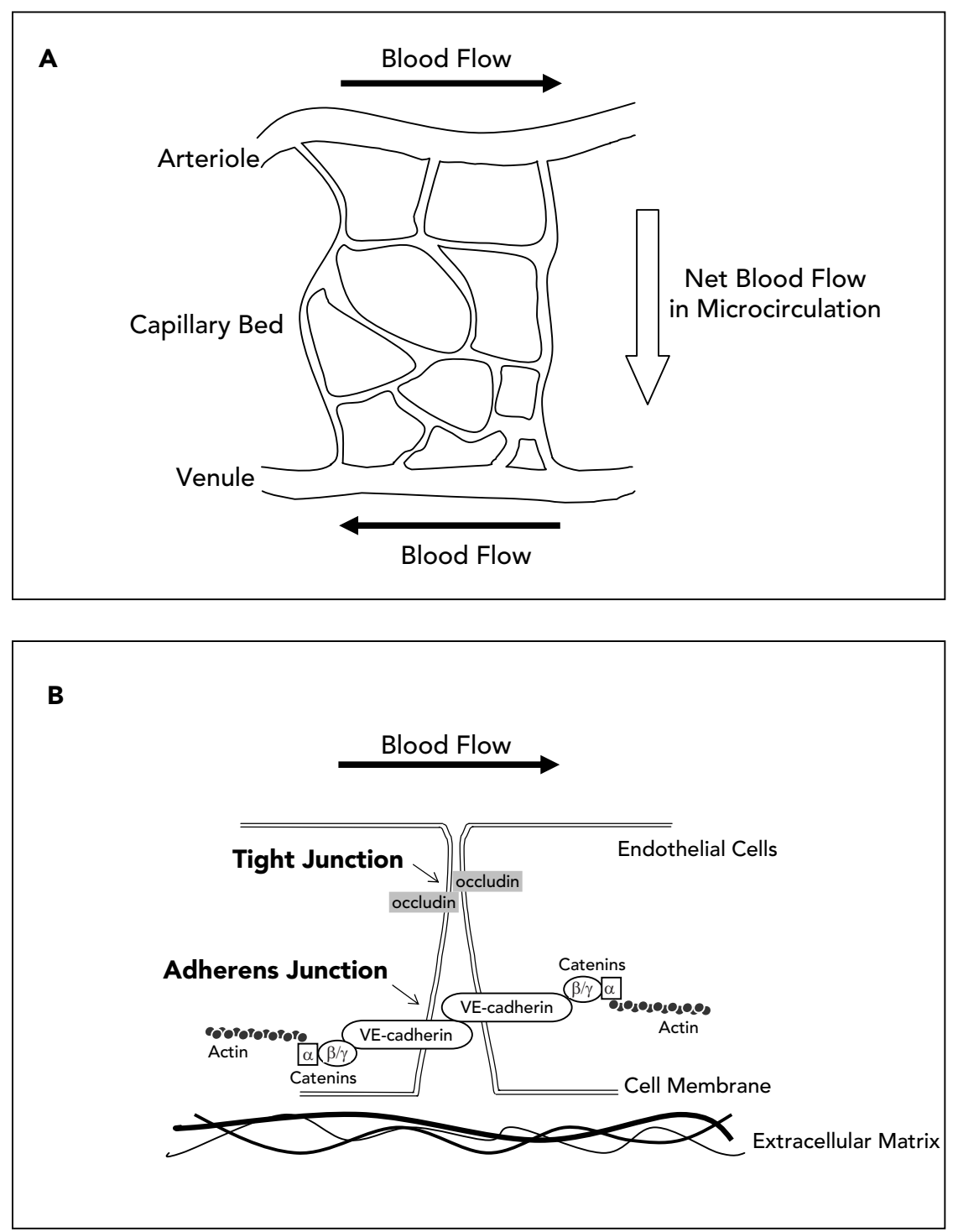

FIGURE 3. Microcirculation and interendothelial junctions. (A) Schematic drawing of blood flow between an arteriole and a venule through a capillary bed. (Adapted from Berne RM, Levy MN, editors. Physiology. 4 ed. St. Louis, MO: Mosby, 1998, ${ }^{14}$ with permission of Elsevier.) (B) Schematic drawing of adherens and tight junctions between two endothelial cells. The extracellular domains of cadherins (at adherens junctions) and occludins (at tight junctions) on an endothelial cell bind to those on an adjacent cell, while their cytoplasmic domains are linked to the cytoskeleton via linker proteins. Vascular endothelial-cadherin (VE-cadherin) is an endothelial-specific cadherin; its intracellular domain interacts with $\beta$ and $\gamma$-catenins, which are linked to actin filaments via $\alpha$-catenin..$^{25,27}$ Occludins also bind to the actin filaments indirectly (not shown). 
differentiates from their fibroblast-like precursors shortly after having migrated through the primitive streak during gastrulation..$^{31,32}$ In the embryonic yolk sac, hemangioblasts form aggregates in which the inner cells differentiate into hematopoietic cell lines and the outer population into EC precursors (i.e., angioblasts). ${ }^{33-35}$ Angioblasts differentiate into ECs and coalesce into a primitive network of vessels known as the primary capillary plexus (F1g. 4A). ${ }^{1,2}$ The plexuses occur in the human embryo in the course of the third week. ${ }^{36}$ This EC lattice created by vasculogenesis then serves as a scaffold for angiogenesis.

During vasculogenesis, embryological mechanisms of pattern formation determine the sites of the primary channels that will later become the major arteries and veins. ${ }^{37}$ This process is predetermined by hereditary factors, although the subsequent development of these channels is influenced by both genetic and environmental factors. Readers interested in the development of arteries and veins are referred to other resources. . $^{1,2,38-41}$

\section{III.B. Angiogenesis}

\section{Vessel Splitting}

Intussusception (also called pillar morphogenesis or intussusceptive angiogenesis) refers to the process by which a single capillary splits into two capillaries from within. ${ }^{1,42}$ As shown in Figure 4B, activated ECs from opposite sides of the capillary protrude into the lumen and fuse, creating a pillar-like structure across the capillary. This pillar elongates in the direction of the vessel axis, leading to the generation of two parallel capillaries.

\section{Vessel Sprouting}

Sprouting (also called tubular morphogenesis or sprouting angiogenesis) refers to the process in which activated ECs branch out from an existing capillary (or venule), extending through the surrounding matrix to form a new vessel ( $F_{1}$. 4B). ${ }^{1,2}$ The following events occur during sprouting: (1) dissolution of the basement membrane and detachment of pericytes at the site of branching; (2) migration of ECs toward the extracellular space and formation of an endothelial sprout; (3) proliferation of ECs trailing behind the leading ECs; (4) formation of lumen in the endothelial sprout; (5) formation of a closed loop with another vessel (i.e., anastomoses); and (6) recruitment of pericytes and formation of the basement membrane around the new vessel. ${ }^{1,2,43}$ The temporal relationship of steps 4-6 seems to vary under dif- 


\section{A}

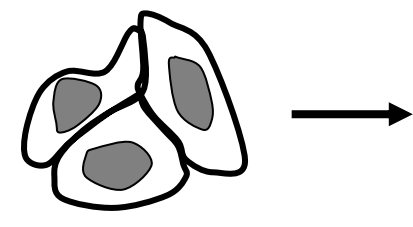

Angioblasts

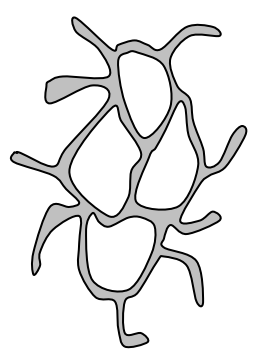

Primitive Vascular Network

B

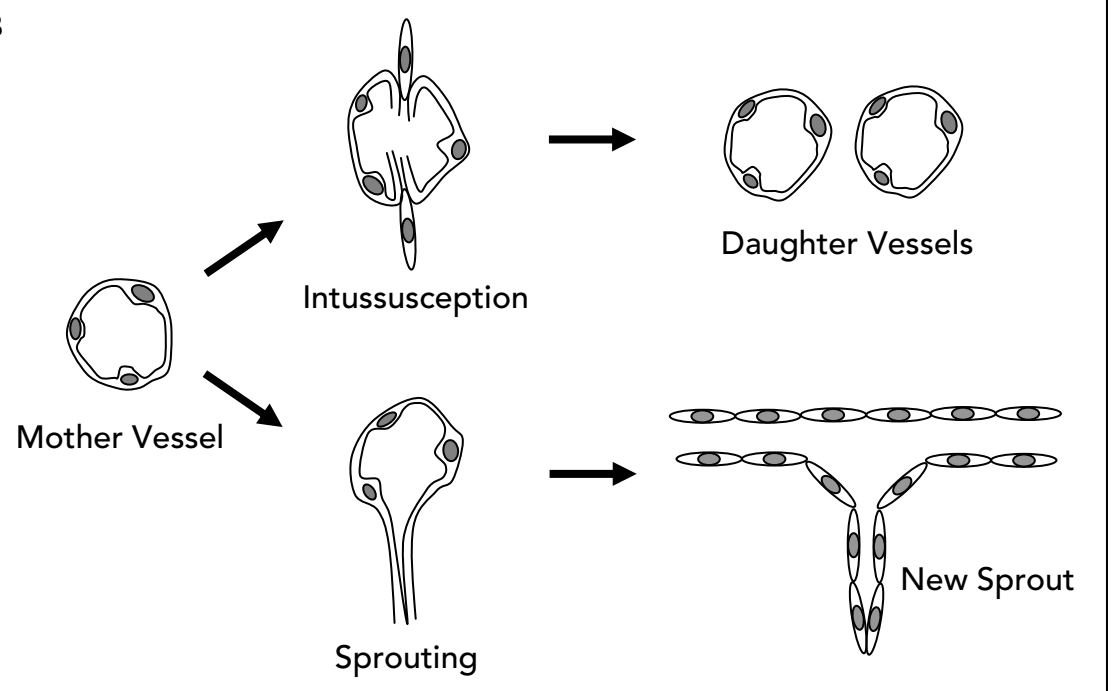

FIGURE 4. The formation of blood vessels. (A) Vasculogenesis: angioblasts (endothelial cell precursors) differentiate and coalesce into a primitive network of vessels known as the primary capillary plexus during the early stage of embryonic development. This endothelial cell lattice then serves as a scaffold for angiogenesis. (B) Angiogenesis: endothelial cells of preexisting vessels (both in embryo and adult) give rise to new vessels through intussusception and sprouting mechanisms. (Adapted with permission from Carmeliet P. Mechanisms of angiogenesis and arteriogenesis. Nat Med 2000; 6:389-95. ${ }^{1}$ @ Nature Publishing Group [http://www.nature.com/]) 
ferent circumstances (e.g., physiological vs. pathological angiogenesis). It is also still debatable whether EC proliferation at the site of branching occurs before any migration takes place.

\section{Central Role of Endothelial Cells in Angiogenesis}

In normal adult tissues, most ECs are not motile and stay in a non-dividing state, having a turnover time of more than 1000 days. ${ }^{44,45}$ In all types of angiogenesis, under either physiological or pathological conditions, the activation of quiescent ECs is the first event to take place. Activated ECs then migrate, proliferate, and remodel the basement membrane (by synthesizing, degrading, and rearranging matrix components) to form new capillaries. ${ }^{1,2,43,46}$ The appreciation of the significance of ECs in angiogenesis has encouraged efforts to isolate and purify EC growth factors and EC-targeting cytokines. ${ }^{47}$ Most of the identified angiogenic factors to date act on ECs directly. Their roles in angiogenesis have been studied using various experimental approaches, as discussed below.

\section{ANGIOGENESIS ASSAYS}

\section{IV.A. In Vivo Angiogenesis Assays}

Most in vivo assays involve observation of capillaries in animals using the following methods: (1) chronic transparent chambers on flanks or ears, such as rabbit ear chambers, dorsal skinfold chambers in rabbits and rodents, and cranial windows in rodents ${ }^{48-58}$; (2) exteriorized tissue preparations, such as the chick chorioallantoic membrane (i.e., CAM assay) and intradermal assays in rodents ${ }^{59-62}$; and (3) in situ preparations, such as corneal micropocket assays in rabbits and rodents. ${ }^{63-66}$ In these assays, tissue environments can be manipulated by the delivery of soluble inhibitors/stimuli or implantation of polymer matrices; matrices containing soluble angiogenic factors or even tumor cells have also been used. ${ }^{43}$ The resulting structural changes in capillary beds or vascularization into matrix implants can be evaluated by quantifying the number, length, and volume of capillaries over time using intravital microscopy. ${ }^{43}$ The functional characteristics of new vessels, such as blood flow rate and vascular permeability, can also be examined. At the end of experiments, vascularized tissues or matrix implants can be excised for electron microscopic, histological, and other examinations.

These in vivo assays provide useful tools for studying the effect of the tissue 
microenvironment on angiogenesis. Furthermore, with advances in molecular genetics, studies using transgenic/knockout mice have shed new light on the genetic mechanisms of angiogenesis. ${ }^{67}$ However, the inherent disadvantages of in vivo studies are that they mostly use nonhuman tissues ${ }^{43}$ and that it is often difficult to dissect out the effects of specific intracellular signaling pathways because of the complexity of the in vivo environment. ${ }^{68}$

\section{IV.B. In Vitro Cell Tubulogenesis Assays}

Numerous forms of in vitro angiogenesis assays have been developed since Folkman and Haudenschild ${ }^{69,70}$ first demonstrated that ECs can form capillary-like structures in cell culture even when blood flow and other cell types are absent. These assays are similar to standard tissue culture models of ECs, ${ }^{71-77}$ except that they allow ECs to undergo a morphological differentiation process leading to the formation of endothelial "tubes"; thus they are also referred to as "tubulogenesis" assays. These methods can be roughly divided into 2D and 3D models, although their experimental conditions and materials (e.g., the origin, passage number, and confluence of ECs; the composition of matrix proteins and cell culture medium; and the presence of other cell types) vary significantly. ${ }^{43,78,79}$

In 2D models (Fig. 5A), ECs cultured on the top of ECM gels or on rigid surfaces coated with the ECM can develop internal vacuoles and join together to form a tube made of one layer of ECs; this endothelial tube then inosculates with others, giving rise to a web-like, planar tubular network on the culture surface. ${ }^{80-82}$ This process is dependent on several factors, including cell density, matrix proteins, and soluble factors. The development of cells into a tubular pattern may need days but is rapid (occurs within hours) when subconfluent ECs are plated on Matrigel, a gelatinous mixture of basement membrane proteins (rich in laminin and type IV collagen) derived from the mouse Engelbreth-Holm-Swarm sarcoma. ${ }^{83,84}$ The 2D Matrigel model has been perhaps the most widely used in vitro angiogenesis assay since it was introduced to this field in the late 1980s. An obvious problem of 2D assays is that endothelial tubes contact fluid culture medium on the outside, while the inside is typically filled with the ECM. ${ }^{70,80,85-87}$ This is the opposite of the situation in vivo, which raises concerns about the applicability of results obtained with $2 \mathrm{D}$ assays to angiogenesis in vivo. Nonetheless, $2 \mathrm{D}$ models provide a simple and convenient approach for examining the tube formation of ECs and have generated a wealth of information on angiogenesis.

In 3D models (Fig. 5B), ECs cultured on the top of or inside 3D gels that represent a surrogate ECM can invade their surrounding matrices, proliferate, and migrate to form tubular networks. ${ }^{88-92}$ When cultured inside a matrix, ECs can be 
A

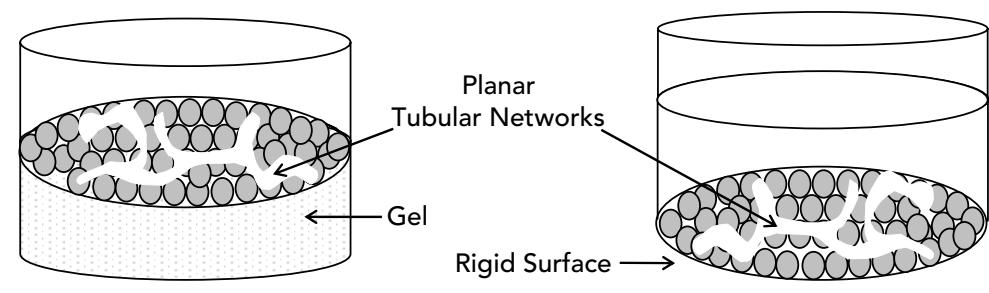

B

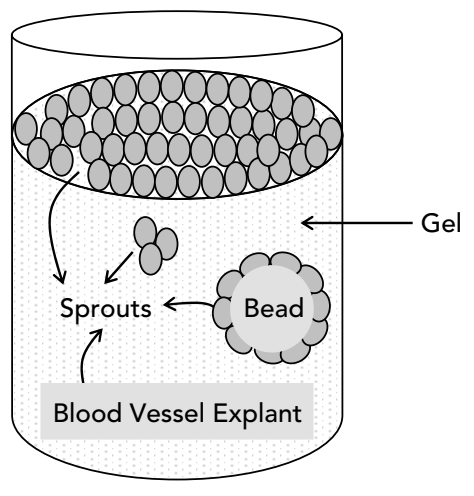

FIGURE 5. In vitro angiogenesis assays. (A) In 2D angiogenesis assays, endothelial cells (gray circles) develop a web-like, planar tubular network on the top of a 3D gel that represents a surrogate extracellular matrix (left panel) or on a rigid surface coated with matrix proteins (right panel). (B) In 3D angiogenesis assays, endothelial cells cultured on the top of or inside a 3D gel can invade into their extracellular space, proliferate and migrate to form tubular networks. When cultured inside a gel, endothelial cells can be suspended as individual cells or aggregates, or can be coated on the surface of microbeads (cell-coated beads) before cell culture. Embedded blood vessel explants, such as rat microvessel fragments and rat aortic rings, have also been used. (Adapted from Vailhe et al. In vitro models of vasculogenesis and angiogenesis. Lab Invest 2001; 81:439-52, ${ }^{79}$ (http://www.nature.com) with permission of Macmillan Publishers, Ltd.) 
suspended as individual cells ${ }^{93,94}$ or aggregates ${ }^{95-97}$ or can be coated on the surface of microbeads (EC-coated beads), which are then embedded inside the matrix. ${ }^{98,99}$ Another form of 3D assays involves the coculture of ECs with stromal cells (fibroblasts or SMCs). ${ }^{100,101}$ The sprouting of ECs from embedded blood vessel explants, such as rat microvessel fragments and rat aortic rings, have also been used. ${ }^{102-106}$

Sprouting of ECs in 3D models is dependent on the same factors as in 2D models, but they replicate several signature features of in vivo sprouting angiogenesis more closely than in 2D assays, notably the invasiveness of ECs into the stromal space. The culture system developed by Montesano et al., ${ }^{90-92}$ in which an endothelial monolayer is established on the surface of a collagen gel and ECs can invade the gel to form capillary-like structures in the presence of angiogenic stimuli, is the first and simplest form of in vitro assay retaining the sprouting capacity of ECs. The occurrence of angiogenesis in this and other similar 3D models where only ECs are present implies that ECs have an endogenous ability to form new vessels. As mentioned above, however, the establishment of functional capillaries requires pericytes. Hence, in vitro models that use isolated rat microvessel fragments or aortic rings as "bases," which contain ECs and other types of vessel wall cells, ${ }^{102-106}$ provide an opportunity for investigating the role of periendothelial cells in angiogenesis. It is worthwhile to note that, recently, the vessel sprouts and neovessels that form in the microvessel model have been shown to retain the ability to mature into a functional microvascular bed in vivo. ${ }^{107}$ When embedded in a collagen gel, isolated microvessel fragments undergo spontaneous angiogenic sprouting, forming neovessels that maintain patent lumen and perivascular cell associations. ${ }^{103}$ Upon implantation, the expanded neovascular mesh can rapidly inosculate with the host microcirculation and mature into a perfused and polarized (artery to vein) circulatory system. ${ }^{107}$ This ability to develop into a stable perfusion bed in vivo indicates that the neovessels formed in this in vitro model did so through a sufficiently native process that preserved vascularizing potential.

\section{IV.C. In Vitro Cell Migration Assays}

The formation of new blood vessels consists of multiple steps and requires a broad spectrum of cell activities. A number of assays using isolated cell culture of vascular cells have proven useful in understanding the different cell activities important for angiogenesis, including cell proliferation, cell-cell and cell-matrix interactions, angiogenic factor production, and cell migration. The migration of vascular wall cells, particularly ECs, is critical for angiogenic sprouting and extension of new vessel elements. The importance of migration in angiogenesis was highlighted in a study of in vivo angiogenesis that inhibited vascular cell proliferation (via irradiation) but 
preserved migratory capability. ${ }^{64}$ In this situation, vascular sprouting and extension of short vascular segments were observed following an angiogenic stimulus. However, expansion of these new segments into a larger network of vessels was impaired.

In general, there are four types of migration assay routinely performed. All use cultured cells but assess migratory behavior differently. The first type involves direct measurement of single cell migratory behavior. In this approach, the migration path of a cell is mapped over time to provide cell migration speed. ${ }^{108-111}$ The second type involves establishing a cell front line and assessment of migration of cells from this front. Typically called monolayer wounding assays, these assays involve the denuding of a thin zone of cells within a cell monolayer and allowing cells at the zone boundary to move into the denuded area. ${ }^{64,112-116}$ In the above two types of assay, cells usually are plated and then migrate on the top of an ECM gel or ECM-coated rigid surface, and thus cell migration in these assays is often considered to be $2 \mathrm{D}$. The third type involves the movement of cells from one side of a barrier membrane to another (e.g., the Boyden chamber assay), and thus cell migration occurs in a 3D setting. ${ }^{117,118}$ Typically, the membranes are porous and are impregnated with ECM to support cell activity. Finally, the fourth class involves migration of cells under a material such as agarose (called the under-agarose assay). Originally developed to assess leukocyte migration, ${ }^{119}$ this assay has since been modified to measure the linear migration of cell populations. ${ }^{77}$ In the linear migration assay, cells migrate out from a cell source underneath a slab of agarose, which provides a mechanical constraint similar to what might be experienced by the cell in vivo. Modeled as a random dispersion of cells in a manner analogous to diffusion of a molecular species, this assay provides a migration coefficient for a cell population. ${ }^{77,120}$

One or combinations of these assays are commonly used to assess modulation of cell traction, by using different ECM coatings and adhesion inhibitors, on cell migration. The role of cell traction in migration is discussed further in Section VI.

\section{MOLECULAR MECHANISMS OF ANGIOGENESIS}

Several decades of research have identified numerous endogenous biochemical factors capable of stimulating or inhibiting angiogenesis. Most of these are growth factors/cytokines and their receptors, ECM constituents, matrix-degrading enzymes, or cell-cell and cell-matrix adhesion molecules (Table 1). ${ }^{2,4,5}$ This section briefly discusses the roles of several major endogenous biochemical factors in physiological angiogenesis. It is important to note that, although most biochemical factors might be involved in both sprouting and intussusceptive angiogenesis, the present state of knowledge comes primarily from investigations on sprouting angiogenesis. ${ }^{4}$ 
TABLE 1. Endogenous Biochemical Factors that Regulate Physiological Angiogenesis $^{a}$

\begin{tabular}{|c|c|}
\hline Name & Function \\
\hline \multicolumn{2}{|c|}{ Growth Factors, Cytokines, and Their Receptors } \\
\hline \multirow[t]{10}{*}{ VEGF } & Vascular endothelial growth factor (VEGF-A) \\
\hline & Binds to its receptor VEGFR-2, which mediates the angiogenic response \\
\hline & Predominant regulator of physiologic and pathologic angiogenesis ${ }^{124-126}$ \\
\hline & Stimulates in vitro and in vivo angiogenesis ${ }^{127,135}$ \\
\hline & Increases endothelial cell permeability ${ }^{129-132}$ \\
\hline & Inhibits endothelial cell apoptosis ${ }^{128}$ \\
\hline & Stimulates endothelial cell proliferation ${ }^{127,415,416}$ \\
\hline & Enhances endothelial cell migration ${ }^{133}$ \\
\hline & $\begin{array}{l}\text { Stimulates the production of matrix proteases and protease inhibitors in } \\
\text { endothelial cells }\end{array}$ \\
\hline & Stimulates the activity and production of endothelial nitric oxide synthase ${ }^{136}$ \\
\hline \multirow[t]{6}{*}{ FGF } & Fibroblast growth factor \\
\hline & Binds to its receptor FGFR \\
\hline & Stimulates in vitro and in vivo angiogenesis $92,145,417$ \\
\hline & Stimulates endothelial cell proliferation ${ }^{148}$ \\
\hline & Enhances endothelial cell migration ${ }^{145,149}$ \\
\hline & Stimulates the production of matrix proteases in endothelial cells ${ }^{147}$ \\
\hline \multirow[t]{5}{*}{ PDGF } & Platelet-derived growth factor \\
\hline & Binds to its receptor PDGFR \\
\hline & Mitogen and chemoattractant for most mesenchymally derived cells ${ }^{154}$ \\
\hline & Stimulates pericyte proliferation ${ }^{158}$ \\
\hline & Increases capillary wall stability ${ }^{159-162}$ \\
\hline \multirow[t]{6}{*}{ TGF- $\beta$} & Transforming growth factor $\beta$ \\
\hline & Binds to the TGF- $\beta$ receptor \\
\hline & Stimulates in vivo angiogenesis in presence of inflammatory response ${ }^{168-172}$ \\
\hline & Stimulates/inhibits in vitro angiogenesis ${ }^{418}$ \\
\hline & $\begin{array}{l}\text { Produces net antiproteolytic activity via modulating the production of } \\
\text { matrix proteases and protease inhibitors }{ }^{150}\end{array}$ \\
\hline & Stabilizes nascent vessels by stimulating matrix production ${ }^{172}$ \\
\hline
\end{tabular}


Name

Function

Growth Factors, Cytokines, and Their Receptors

\begin{tabular}{|c|c|}
\hline \multirow[t]{4}{*}{ Ang-1 } & Angiopoietin-1 \\
\hline & Binds to the Tie- 2 receptor \\
\hline & $\begin{array}{l}\text { Stabilizes nascent vessels by tightening the interaction between } \\
\text { endothelial and periendothelial cells } s^{173,175}\end{array}$ \\
\hline & Inhibits permeability ${ }^{176}$ \\
\hline \multirow[t]{4}{*}{ Ang-2 } & Angiopoietin-2 \\
\hline & Binds to the Tie-2 receptor \\
\hline & Antagonizes Ang-1 signaling and destabilizes the endothelium ${ }^{173,177}$ \\
\hline & Angiogenic in the presence of VEGF via loosening of periendothelial cells ${ }^{220}$ \\
\hline \multicolumn{2}{|c|}{ Extracellular Matrix, Integrins, and Matrix Proteases } \\
\hline \multirow[t]{4}{*}{$\mathrm{ECM}$} & Extracellular matrix \\
\hline & Contains various proteins and proteoglycans \\
\hline & $\begin{array}{l}\text { Provides both mechanical and biochemical regulatory functions to } \\
\text { cells }^{18-22,180,181}\end{array}$ \\
\hline & $\begin{array}{l}\text { Some components stimulate angiogenesis while some inhibit } \\
\text { angiogenesis }\end{array}$ \\
\hline \multirow[t]{6}{*}{$\alpha_{v} \beta_{3}$} & Mediates endothelial cell attachment, spreading, and migration ${ }^{419}$ \\
\hline & Inhibits endothelial cell apoptosis ${ }^{199}$ \\
\hline & Highly expressed on activated endothelial cells ${ }^{420,421}$ \\
\hline & Present on angiogenic capillary sprouts ${ }^{197,198}$ \\
\hline & Localizes MMP-2 to capillary sprouts ${ }^{198}$ \\
\hline & Required for FGF-stimulated angiogenesis in vivo ${ }^{195,196}$ \\
\hline$\alpha_{v} \beta_{5}$ & Required for VEGF-stimulated angiogenesis in vivo ${ }^{195,196}$ \\
\hline \multirow[t]{3}{*}{ MMPs } & Matrix metalloproteinases \\
\hline & Degrade ECM components ${ }^{203,204}$ \\
\hline & Mediate cell migration and matrix remodeling 203,204 \\
\hline \multirow[t]{3}{*}{ TIMPs } & Tissue-inhibitors of MMPs \\
\hline & Inhibitors of MMPs \\
\hline & $\begin{array}{l}\text { Stabilize nascent vessels via preventing proteolytic breakdown of the } \\
\text { vascular } \mathrm{ECM}^{203,204}\end{array}$ \\
\hline
\end{tabular}


TABLE 1. Continued.

\begin{tabular}{|c|c|}
\hline Name & Function \\
\hline \multicolumn{2}{|c|}{ Growth Factors, Cytokines, and Their Receptors } \\
\hline \multirow[t]{3}{*}{ PAs } & Plasminogen activators \\
\hline & Activators of plasminogen 202,203 \\
\hline & Mediate cell migration and matrix remodeling 202,203 \\
\hline \multirow[t]{3}{*}{ PAls } & Plasminogen activator inhibitors \\
\hline & Inhibitors of PAs \\
\hline & $\begin{array}{l}\text { Stabilize nascent vessels via preventing proteolytic breakdown of the } \\
\text { vascular } \mathrm{ECM}^{202,203}\end{array}$ \\
\hline \multicolumn{2}{|c|}{ Cell Junction Proteins } \\
\hline \multirow[t]{5}{*}{ VE-cadherin } & Vascular endothelial-cadherin (cadherin 5) \\
\hline & Endothelial-specific cadherin ${ }^{25,27}$ \\
\hline & May mediate endothelial cell permeability ${ }^{130}$ \\
\hline & Mediates the VEGF-induced endothelial survival effect ${ }^{216}$ \\
\hline & Mediates confluence-induced growth stop signal (contact inhibition) ${ }^{216}$ \\
\hline \multirow[t]{3}{*}{ PECAM-1 } & Platelet endothelial cell adhesion molecule-1 (CD31) \\
\hline & Cell surface glycoprotein on hemopoietic and endothelial cells ${ }^{217}$ \\
\hline & Involves in the organization of adherens junctions ${ }^{216}$ \\
\hline
\end{tabular}

\footnotetext{
a Selected list
}

(Adapted with permission from Papetti M, Herman IM. Am J Physiol Cell Physiol 2002; 282(5):C94770. ${ }^{5}$ (C) The American Physiological Society; and Conway EM, Collen D, Carmeliet P. Cardiovasc Res 2001; 49:507-21, ${ }^{2}$ with permission of Elsevier.)

\section{V.A. Roles of Soluble Factors and Their Receptors}

\section{Vascular Endothelial Growth Factor (VEGF) and Its Receptors}

The most potent and perhaps the most well-characterized angiogenic stimulus is VEGF (also known as VEGF-A). VEGF is a highly conserved homodimeric glycoprotein and has six isofoms as a result of alternative splicing. ${ }^{121-123}$ The proangiogenic effect of VEGF is mediated by its functional receptor VEGFR-2 (also 
called KDR or Flk-1), which is expressed predominantly in ECs. VEGFR-2 is a transmembrane protein with intrinsic tyrosine kinase activity belonging to the classic receptor tyrosine kinase (RTK) superfamily. ${ }^{124-126}$ VEGF binding causes VEGFR-2 activation, a process involving receptor dimerization and autophosphorylation of specific tyrosines in the cytoplasmic domain of VEGFR-2. Activated VEGFR-2 sets off an intracellular signal cascade leading to multiple cellular responses and a complete angiogenic process (Table 1). ${ }^{124-136}$

$\mathrm{VEGF}$ is produced by a wide variety of cell types, including $\mathrm{EC}$ s themselves. ${ }^{121-123}$ A major regulator of VEGF expression is local oxygen concentration. Cells that are short of oxygen (or have an increase in metabolic demands) upregulate the production of VEGF, which in turn acts on ECs, causing them to proliferate and invade the hypoxic tissue to supply it with new blood vessels. The expression of VEGFR-2 is also upregulated by chronic hypoxia. ${ }^{137}$ Therefore, not only is the VEGF/VEGFR-2 system capable of stimulating the entire angiogenic process, but it also acts as a key mediator of hypoxia-induced angiogenesis. ${ }^{138-141}$ This mechanism ensures that every region of the body is sufficiently vascularized and oxygenated, although it also underlies pathologies associated with aggressive outgrowth of blood vessels (e.g., cancer and diabetic retinopathy). ${ }^{142,143}$

\section{Fibroblast Growth Factor (FGF) and Its Receptors}

FGF-1 (acidic FGF) and FGF-2 (basic FGF) were among the first growth factors shown to stimulate angiogenesis. ${ }^{144,145}$ They are ubiquitously expressed small polypeptides belonging to a large family of structurally related proteins, which all contain heparin and heparan sulfate (HS) binding domains. ${ }^{146}$ Like VEGF, both FGFs promote several EC activities that are critical to angiogenesis (Table 1). ${ }^{92,145,147-150}$ Unlike VEGF, however, the action of FGFs is not specific to ECs. They act on most cells derived from embryonic mesoderm and neuroectoderm, including fibroblasts, ECs, and pericytes. ${ }^{146}$

The cellular effects of FGFs are mediated via specific binding to high-affinity receptors for FGF (FGFR). ${ }^{151}$ There are four distinct FGFRs; all of them are members of the RTK superfamily, and receptor dimerization by FGF is facilitated by heparin. ${ }^{151,152}$ Low-affinity binding sites for FGF have been identified in proteoglycans containing HS side chains (HSPG). ${ }^{153}$ These HSPG are found on the cell surface and in the ECM. It has been suggested that binding to HSPG in the ECM results in storage of FGF and protection of FGF from inactivation in the extracellular space; matrix-associated FGF can be released upon ECM degradation. ${ }^{153}$ 


\section{Platelet-Derived Growth Factor (PDGF) and Its Receptors}

PDGF was originally purified from platelets, but it has since been demonstrated that many other cell types including fibroblasts, macrophages, and ECs produce PDGF. ${ }^{154}$ The effect of PDGF is mediated by PDGF receptors, which are also members of the RTK superfamily. In blood vessel walls, PDGF receptors can be found in ECs, pericytes, and SMCs. ${ }^{155-158}$

Paracrine signaling via PDGF and its receptor plays a central role in blood vessel maturation. ${ }^{159-162}$ In vivo studies have shown that the proliferation and migration of pericytes along angiogenic sprouts is mediated by PDGF, possibly secreted from ECs to recruit pericytes; animals with a PDGF deficiency had abnormal, poorly formed immature blood vessels. ${ }^{159-162}$ The first US FDA-approved angiogenesis-stimulating medicine is a wound healing gel called Regranex. It contains recombinant human PDGF and was approved in 1997 to treat diabetic foot ulcers. ${ }^{163,164}$

\section{Transforming Growth Factor- $\beta$ (TGF- $\beta$ ) and Its Receptors}

Members of the TGF- $\beta$ family are multifunctional cytokines with effects on cell proliferation, migration, inflammation, and angiogenesis. ${ }^{165,166}$ These effects are mediated by TGF- $\beta$ receptors, which are receptor-type serine/threonine kinases. ${ }^{165,166}$ Both TGF- $\beta$ and their receptors are expressed in a full spectrum of cell types, including ECs and pericytes in the microcirculation. ${ }^{167}$ Like FGF-2, TGF- $\beta$ can also be found in the extracellular space.

The effect of TGF- $\beta$ on angiogenesis varies depending on experimental conditions. TGF- $\beta$ has been shown to induce angiogenesis in vivo. This induction is mediated by the effect of TGF- $\beta$ on recruiting inflammatory cells (e.g., monocytes and macrophages) that release VEGF, FGF-2, and PDGF. ${ }^{168-172} \mathrm{On}$ the other hand, in vitro studies have found that the production of ECM proteases and their inhibitors in ECs is tilted toward antiproteolysis by TGF- $\beta$ (see Section V.B.3, Matrix Proteases). ${ }^{150}$ It was also found that TGF- $\beta$ mediates the inhibition of EC proliferation upon EC-pericyte contact in a coculture system. ${ }^{167}$ Together these effects inhibit the initiation of angiogenesis but are critical in stabilizing nascent, immature blood vessels. Given the pleiotropic effects of TGF- $\beta$ on different cell types, it likely modulates angiogenesis through several mechanisms.

\section{Angiopoietins and Their Receptors}

The angiopoietins (angiopoietin-1 [Ang-1] and angiopoietin-2 [Ang-2]) are ligands for an endothelial-specific receptor called Tie-2, which is a member of the RTK 
superfamily. Angiopoietins are not mitogenic to ECs, but they assist in the communication of ECs with their surrounding mesenchyme by binding to Tie-2. ${ }^{173}$ Ang-1 activates the Tie-2 receptor and promotes the recruitment of pericytes and SMCs, therefore playing a role in stabilizing and maintaining vascular integrity. ${ }^{173-176}$ As an antagonist of Ang-1, Ang-2 competes with Ang-1 for binding of Tie-2 and blocks vessel stabilization from Tie-2 signaling, thereby loosening the interactions of ECs with pericytes and the ECM (i.e., vessel destabilization). ${ }^{173,177}$ While all ECs in adult animals have Tie-2, in vivo studies have shown that Ang-1 is expressed in quiescent ECs, and Ang-2 is only found at sites of vascular remodeling. ${ }^{177-179}$

\section{V.B. Roles of ECM, Integrins, and Matrix Proteases}

\section{The ECM}

The ECM is a complex interconnected network of proteins and proteoglycans that provide both mechanical and biochemical regulatory functions to cells. ${ }^{18-22,180,181}$ As already mentioned in Section II, ECs are supported by a thin, sheet-like basement membrane mainly made of laminin, type IV collagen, and proteoglycans. The basement membrane is only a few nanometers thick, forming a continuous bond with the underlying loose, interstitial connective tissue whose great bulk is type I collagen. ${ }^{18-22,180,181}$ The components of the EC basement membrane and underlying interstitial matrix vary depending on type of organ and whether the vessels are quiescent or undergoing remodeling. The latter observation has prompted investigators to study how ECM components affect angiogenesis using various in vivo and in vitro assays mentioned above. In vivo studies show that implanted matrices made of fibrin or Matrigel result in blood vessel ingrowth. ${ }^{182,183}$ In 3D assays, sprouting angiogenesis occurs when ECs, rat aortic rings, or rat microvessel fragments are embedded in type I or III collagen, fibrin, or a plasma clot. ${ }^{90,103,104,184,185}$ ECs can form planar tubular networks on the surface of ECM gels made of type I or III collagen, fibrin, gelatin, or Matrigel; in some studies, fibronectin or laminin is mixed in the gel. ${ }^{84,88,182,186-188}$ The above investigations focus on the regulation of angiogenesis by the bulk components of the ECM. However, the ECM consists of a variety of proteoglycans and proteins that are not as abundant but yet play a regulatory role in angiogenesis. Readers interested in this regard are referred to other resources. ${ }^{2,4,5}$

\section{Integrins}

The effects of ECM constituents are mediated primarily by their receptors on the cell surface, called integrins. Integrins are transmembrane heterodimers composed 
of $\alpha$ and $\beta$ subunits with noncovalent association. ${ }^{189}$ The cytoplasmic domain of integrin interacts with cytoskeletal proteins and signaling molecules in the focal adhesion sites, and the extracellular domain binds to extracellular ligands. ${ }^{189-194}$ This structural feature of integrins enables them to mediate "outside-in" signaling, in which extracellular ligands induce the intracellular signaling cascade via integrin activation. Of the more than 20 integrin heterodimers, $\alpha_{v} \beta_{3}$ has been studied most extensively for its association with angiogenesis. ${ }^{195,196} \alpha_{\mathrm{v}} \beta_{3}$ is minimally expressed on normal, resting ECs, but it is significantly upregulated on activated ECs during cytokine- or tumor-induced angiogenesis. ${ }^{197,198} \alpha_{\mathrm{v}} \beta_{3}$ affects angiogenesis in several ways, notably the enhancement of endothelial survival and the localization of MMP2 (see the following section) to the tips of sprouting blood vessels, thereby increasing cell migration speed and matrix degradation in this region. ${ }^{198,199}$ Another $\alpha_{v}$ integrin associated with angiogenesis is $\alpha_{\mathrm{v}} \beta_{5}{ }^{195,196}$ Angiogenesis induced by FGF-2 depends on $\alpha_{v} \beta_{3}$-mediated signaling events, whereas that induced by VEGF depends on $\alpha_{\mathrm{v}} \beta_{5}{ }^{195,196}$ This implies that different growth factors may stimulate angiogenesis via distinct integrins.

\section{Matrix Proteases}

For ECs to emigrate from their resident site and take on the proliferative and invasive phenotypes that are associated with sprout formation, they need to loosen or degrade the surrounding ECM. In fact, collagen must be degraded in order for angiogenesis to occur in vitro. ${ }^{200}$ Proteolysis of the ECM is achieved primarily by two protease families. One is a large family of secreted or membrane-associated zinc-dependent enzymes called matrix metalloproteinases (MMPs), and the other is the serine proteases - in particular, the plasminogen activator (PA)-plasmin system. ${ }^{201-204}$ In addition to ECM degradation, these proteases are also important for the release of angiogenic stimuli (e.g., FGF-2 and TGF- $\beta$ ) from the ECM pool and the exposure of cryptic binding sites in the ECM to promote cell adhesion and migration. ${ }^{1,2}$

In the MMP family, MMP-1, -2, and -9 are frequently implicated in angiogenesis, because MMP-1 degrades type I collagen and MMP-2 and -9 degrade type IV collagen, which are the protein backbones of the interstitial ECM and basement membrane, respectively. ${ }^{200,204-207}$ As to the PA-plasmin system, the activation of plasminogen in tissues is primarily regulated by the urokinase-type PA (uPA). ${ }^{201-203}$ These matrix proteases are produced by a variety of cell types, including ECs, pericytes, and SMCs in blood vessel walls. ${ }^{201-204,208,209}$

MMPs and PAs are expressed as latent enzymes and are activated locally when needed. Their activity is tightly controlled by several mechanisms to prevent excessive 
ECM breakdown and guide directional cell migration and invasion. Directionality of protease activity arises by a complex, localized vesicular shedding of MMPs from specific areas of the cell plasma membrane. EC-derived vesicles contain the latent forms of MMP-2 and -9 (proMMP-2,-9) as well as other proteins that regulate their activity; VEGF and FGF-2 stimulate the shedding of vesicles containing MMPs. ${ }^{210}$ The activity of MMPs and PAs is regulated by their endogenous inhibitors, tissue inhibitors of metalloproteinases (TIMPs) and PA inhibitors (PAIs), respectively. ${ }^{201-204}$ Protease inhibitors are secreted by cells near areas of active protein degradation in order to protect uninvolved matrices. ${ }^{211}$ In addition, many cells have receptors on their surface that can bind these proteases before they are activated, thereby confining the enzyme to the site where it is needed - for example, the binding of MMP-2 to $\alpha_{\mathrm{v}} \beta_{3}$ on the surface of invasive cells. ${ }^{198}$

Generally speaking, TIMPs and PAIs are considered to be angiogenic inhibitors, although they play an important role in stabilizing nascent vessels by preventing proteolytic breakdown of the basement membrane surrounding fragile new vessels. ${ }^{1,2}$ On the other hand, while MMPs and PAs stimulate angiogenesis, fragments of MMP-2 and plasminogen, called PEX and angiostatin, respectively, have strong anti-angiogenic properties via inhibiting $\mathrm{EC}$ proliferation and inducing $\mathrm{EC}$ apoptosis. ${ }^{212-215}$

\section{V.C. Roles of Cell Junction Proteins}

As described in Section II, ECs form a tight monolayer through junction proteins to control vascular permeability. Junction proteins also play an important role in transmitting signals for cell survival, proliferation, and assembly. The two most extensively studied $\mathrm{EC}$ junction proteins that are involved in angiogenesis are $\mathrm{VE}$-cadherin and platelet endothelial cell adhesion molecule-1 (PECAM-1 or CD31). ${ }^{216}$

$\mathrm{VE}$-cadherin is a member of the calcium-dependent cadherin family of transmembrane proteins that mediate homotypic cell-cell adhesion at adherens junctions. ${ }^{25,27} \mathrm{VE}$-cadherin is endothelial specific, and its intracellular domains interact with $\beta$-, $\gamma^{-}$(plakoglobin), and p120 catenins. $\beta$ - and $\gamma$-catenins bind $\alpha$-catenin, which in turn binds to the actin filaments (F1g. 3B) ${ }^{25,27}$ In this way, the cytoplasmic structural components of ECs are linked to adherens junctions. The cadherin/catenin complexes mediate several signaling events, notably VEGF-induced surviving signals and confluence-induced growth stop signals (contact inhibition). PECAM-1 is a member of the immunoglobulin superfamily of cell adhesion molecules and is expressed primarily at the cell-cell junctions of ECs. ${ }^{217}$ Like VE-cadherin, PECAM-1 also physically interacts with $\beta$-catenin and thus participates in shaping the adherens junctions. ${ }^{218,219} \mathrm{VE}$-cadherin and PECAM-1 in conjunction control the organiza- 
tion and maintenance of a quiescent EC monolayer. ${ }^{216}$ When ECs migrate during angiogenesis, cell-cell junctional complexes are transiently dissembled but later reassembled when a new vessel has been established.

\section{V.D. Orchestrated Interactions Between Biochemical Factors}

Although the roles of biochemical factors in angiogenesis have been discussed above separately, it is important to note that the activity of an angiogenic stimulus or inhibitor depends on the presence and/or concentration of other factors in the environment of the responding ECs. ${ }^{1,2}$ For example, as mentioned above, TGF$\beta$-induced angiogenesis depends largely on the recruitment of inflammatory cells to release angiogenic stimuli, and $\alpha_{\mathrm{v}} \beta_{3}$ and $\alpha_{\mathrm{v}} \beta_{5}$ integrins are required in FGF-2- and VEGF-induced angiogenesis, respectively. Furthermore, some of these biochemical factors can upregulate or downregulate the expression of other biochemical factors-for instance, VEGF can induce the expression of several integrins, matrix proteases, and protease inhibitors, while VEGF itself is induced by FGF-2, PDGF, and TGF- $\beta .^{4,5}$ In addition, while the production of PAs and PAIs is tilted toward antiproteolysis by TGF- $\beta$, it is tilted toward enhanced proteolysis by FGF-2. ${ }^{150}$ Such a complex interdependence (or competition) among them may explain why angiogenic factors often exhibit context- and/or concentration-dependent activities in various experimental conditions. ${ }^{1,2}$

Another aspect of the complexity of angiogenesis regulation is the timely expression of specific angiogenic stimuli or inhibitors. Depending on their functions, biochemical factors arise at different stages of angiogenesis. At the beginning of angiogenesis, Ang-2 synergizes with VEGF to loosen/destabilize vessels, ${ }^{220}$ while MMPs and PAs break down the ECM and liberate angiogenic factors stored in the ECM pool (e.g., FGF-2 and TGF- $\beta$ ). These and other factors together promote the migration, proliferation, and tube formation of ECs in the extracellular space, where widespread breakdown of the ECM is prevented in part by localizing matrix proteases via binding to $\alpha_{\mathrm{v}} \beta_{3}$ on activated ECs. In the later stage of angiogenesis, the activity of TIMPs and PAIs overrides that of matrix proteases and thus provides a steady, supportive scaffold for fragile new vessels. Further stabilization and maturation of nascent vessels involve PDGF and Ang-1, which promote the interaction of ECs with pericytes and the ECM. As a nascent, leaky vessel matures into a durable one, the level of $\alpha_{v} \beta_{3}$ decreases, and adjacent ECs form close junctions with each other via VE-cadherin, PECAM-1, and other adhesion molecules.

Recent advances in DNA microarray technology have provided a powerful and efficient approach for studying the differential expression of a large number of genes simultaneously. ${ }^{221}$ Several groups have applied DNA microarray technology 
for relatively comprehensive studies of the gene expression profiles of ECs during angiogenesis, providing significant insight into the temporal and spatial involvement of angiogenic factors. ${ }^{222,223}$ Hundreds of differentially expressed genes have been identified. In general, genes that are involved in the proliferation, survival, and matrix remodeling of ECs are upregulated during the tube-forming process. ${ }^{222}$ However, it has not yet been established how the differential gene expression is regulated and how these gene regulations contribute to angiogenesis. The microarray results provide a clue for selecting the candidate genes for future studies of the molecular regulation of angiogenesis. ${ }^{221,222}$

\section{MECHANICAL MODULATION OF ANGIOGENESIS}

All cells in the body, including ECs, are subjected to mechanical forces that either are self-generated or originate from the environment during common physiological processes. The forces acting on and within a cell can be described in terms of stress. ${ }^{24}$ Mechanical stress is a second-order symmetric tensor that determines the traction vector acting on a specific surface. ${ }^{225,226}$ The components of the stress tensor have units of force per unit area. The traction vector acting on a surface can be decomposed into normal components (tension and compression) and shear components. Cell deformation in response to intrinsic or extrinsic stress is influenced by the mechanical and structural properties of the cell and can be expressed as a second-order symmetric strain tensor. The components of the strain tensor are usually measured as a change in length relative to an initial reference length and, for an elastic material, are uniquely determined by the components of the stress tensor through the constitutive model and associated material coefficients. These mechanical terms, derived for inert materials, must be considered in light of the active metabolism of living cells. ${ }^{224}$

Forces generated by the cell itself are necessary to carry out fundamental cellular events. The most prominent force-generating process is actomyosin contractility. ${ }^{227}$ When cells sense a change in their external loading, they actively alter their internal forces to counteract external forces. There is a growing recognition that the balance between internally generated and externally applied forces is a key determinant of a cell's fate and function. ${ }^{228,229}$ In contrast to the wealth of information concerning the biochemical aspect of angiogenesis regulation, knowledge of the contribution of mechanical forces in angiogenesis is very limited. This section examines the characteristics of intrinsic and extrinsic forces within the mechanical microenvironment of a cell and highlights their implications for angiogenesis. The discussion is focused on postnatal, physiological angiogenesis. 


\section{VI.A. Role of Cell-Generated Forces in Angiogenesis}

\section{Cytoskeleton}

The cytoplasm of eukaryotic cells is filled with a highly organized, dynamic network of protein fibers called the cytoskeleton, which consists primarily of three types: actin filaments (also called microfilaments), intermediate filaments, and microtubules. ${ }^{230-232}$ The cytoskeleton provides a structural framework and forces for maintaining cell shape, shape change, and cytoplasmic organization. For anchorage-dependent cells such as ECs, the ability to apply cytoskeletal forces against the ECM through integrin receptors is essential for shape stability and cell survival. ${ }^{228,233,234}$

\section{Cytoskeletal Tension and Cell Traction}

Most mammalian cells assume a spherical shape in suspension. Upon contact with ECM components, a cell may rearrange its cytoskeletal proteins to spread and form numerous adhesion sites with the ECM, transforming into a somewhat flattened shape that is common to anchorage-dependent cells. ${ }^{228,233}$ Establishing and maintaining such a flattened shape requires cellular forces that are primarily generated by actin-myosin contraction. Contractile bundles of actin and myosin filaments (i.e., stress fibers) form an interconnected actin network, spanning the entire cytoplasm and terminating on the basal, apical, and lateral surfaces of the cell, as well as on the nuclear membrane. ${ }^{235-240}$ On the basal surface, stress fibers terminate at an array of well-established connections between the cell and ECM known as focal adhesions (FAs) (F1g. 6). FAs consist of clustered integrins that span the plasma membrane, interacting with specific ECM ligands on the outside and with bundles of actin filaments via cytoskeletal associated proteins (e.g., paxillin, $\alpha$-actinin, and vinculin) on the inside. ${ }^{241-243}$ In this way, cytoskeletal forces are transmitted via integrins to the surrounding ECM, which acts as an external support for anchoring the cell and balancing the forces that maintain cell shape. ${ }^{241-243}$ Thus, the adherent cell is under tension due to the ECM's resistance to deformation.

The tension residing in the cytoskeleton of a resting adherent cell (often referred to as prestress, initial tension, or resting tension) is a major determinant of cell shape and affects intracellular signal transduction and gene expression. ${ }^{12,229,233,244,245}$ Cytoskeletal tension is not static and can change, by rearranging the cytoskeletal proteins and FAs, without external stimuli during specific cellular events such as cell division and migration. Cytoskeletal tension can also change when the cell receives and responds to external biochemical or mechanical stimuli. It is important that cellular responses to an external stimulus may 


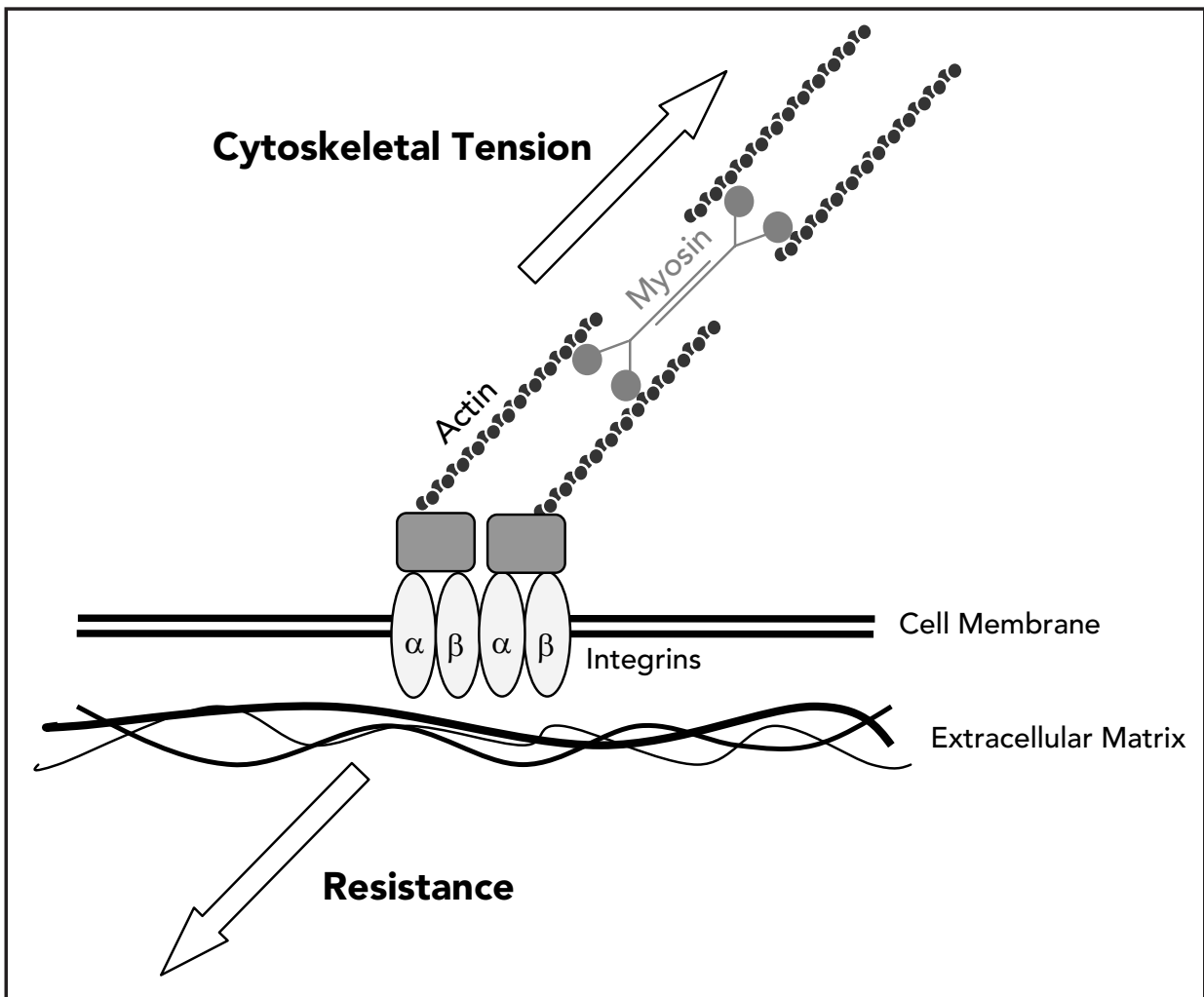

FIGURE 6. Forces on focal adhesions. Cultured cells form specialized contact sites with the underlying substratum called focal adhesions. They contain clustered integrin receptors whose extracellular domain binds to the extracellular matrix, and intracellular domain interacts with bundles of actin filaments via cytoskeletal associated proteins (the boxes between integrins and actin filaments). Myosin II-driven contractile forces applied to a cluster of integrins can lead to the development of tension if the surrounding extracellular matrix is sufficiently rigid. (Reprinted with permission from Burridge and ChrzanowskaWodnicka. Annu Rev Cell Dev Biol 1996; 12:463-518, ${ }^{243}$ (C1996 by Annual Reviews, http: //www.annualreviews.org; and Geiger B, Bershadsky A. Cell 2002; 110:139-42, ${ }^{242}$ with permission of Elsevier.)

differ depending on the level of the initial tension (or, the "mechanical tone") in the cell. ${ }^{12,228,244,245}$

The amount of the initial tension in an adherent cell is collectively controlled by its interaction with the ECM (see Section VI.B) and the cell's actomyosin contractile machinery. Actomyosin contraction is driven by the motor protein myosin II and is triggered by the phosphorylation of the myosin light chain (MLC) in nonmuscle 
and smooth muscle cells. ${ }^{227}$ Increasing evidence indicates that the Rho GTPase (a member of the Rho family of GTP-binding proteins) and its effector Rho-associated kinase $(\mathrm{ROCK})$ are important regulators of myosin activity. Inactivating Rho or ROCK diminishes cell contractility and consequently inhibits the formation of tension-dependent structures such as stress fibers and FAs. ${ }^{246-249}$

The intracellular contractile force exerted on the ECM (also called the traction force, cell traction, or substrate traction) is essential for the assembly of ECM fibrils and cell migration. ${ }^{250-254}$ The study of tractions exerted at the cell/substratum interface by individual cells (without cell-to-cell contact) has been based mostly on measuring the deformation of elastic substrata. ${ }^{221,227,251,255,256}$ This approach was first developed by Harris and colleagues in 1980, using silicone rubber film for the cell culture substratum, which wrinkles in response to cellular traction forces. ${ }^{221,257}$ Recently, several groups have succeeded in measuring traction forces and relating them to FA assembly. These studies demonstrate conclusively that FAs transmit cytoskeletal forces in the range of several nanonewtons per $\mu \mathrm{m}^{2}$ to the substratum. ${ }^{227}$ In stationary, nonmotile cells, the size of FAs is proportional to the local transmitted force, and FAs exhibit directional assembly in response to local forces. ${ }^{258}$

Finally, in addition to the ECM, microtubules have also been implicated in providing mechanical support for the tensed actin network in a cell's cytoplasm. Based on the observation of an increase in traction forces upon the disruption of microtubules, it is thought that microtubules are under compression and that compressive loads could be transferred from microtubules to the ECM. ${ }^{259-262}$ Cells in contact with other cells can also transmit forces to their neighbors through cell-cell junctions. ${ }^{233}$ Cells in a confluent monolayer generally form fewer and smaller FAs with the ECM than subconfluent cells, ${ }^{263,264}$ suggesting a decreased tension at the interface between the ECM and a cell monolayer. The interactions between groups of cells and the ECM define "the resting stress field" within a tissue and are essential for guiding tissue development, remodeling, and maintaining tissue homeostasis. ${ }^{233,265}$

\section{Measurement of Endothelial Cell-Generated Forces}

Quantitative data on the traction forces generated by individual ECs and contractile forces generated by an EC monolayer are available. EC tractions have been measured using the "traction force microscopy" technique developed by Wang and Dembo. ${ }^{111,266}$ For a migrating bovine aortic EC cultured on an ECM-coated polyacrylamide gel, the overall level of traction stresses (i.e., the average of the magnitude of traction stresses across the entire projected cell area) is about $1 \sim 2 \times 10^{4}$ $\mathrm{dyn} / \mathrm{cm}^{2}$, which is the same order as a migrating fibroblast-like cell. ${ }^{111,267}$ Kolodney and Wysolmerski ${ }^{268}$ used an isometric force transducer to measure the isometric 
force developed by a monolayer of human umbilical vein ECs grown on a collagen matrix. These cells generated a force per cellular cross-sectional area of $10^{5} \mathrm{dyn} / \mathrm{cm}^{2}$, which is the same order as fibroblasts but smaller than skeletal and smooth muscles by one order of magnitude.

\section{Function of Cell Traction in Angiogenesis}

Cellular traction forces are involved in several processes critical to angiogenesis, including cell migration, matrix remodeling, and tube formation.

\section{a. Cell Migration}

Traction forces are the driving force for cell movement. ${ }^{251-254}$ In order to generate a net migration, an adherent cell must push or pull against the substratum via cell/substratum contact sites while crawling over it; the substratum in turn exerts a counter force on the cell via the same contact sites, propelling the translocation of the cell body. ${ }^{221}$ The application of traction force microscopy to study the mechanical stresses generated by migrating fibroblasts and ECs has revealed that tractions are organized in a centripetal pattern, with the backward and forward tractions located in the advancing front and trailing back of the cell body, respectively (F1g. 7). ${ }^{111,269-}$ ${ }^{273}$ In general, regional traction forces are greatest near the leading edge of the cell and smallest in the central/nuclear region of the cell. ${ }^{111,266,269-273}$ Traction forces in the tail are strong as well but are thought to reflect passive resistance to the active pulling forces in the front generated by actin-myosin contraction. ${ }^{272,273}$ Previously it was found that inhibitors of Rho or ROCK1 reduced the capacity of ECs to form tubular networks in vitro and in vivo ${ }^{274}$ and that the inhibition of ROCK1 dramatically decreased the traction force and subsequent migration speed of ECs. ${ }^{111}$ Together these findings help define a mechanism by which the Rho/ROCK pathway and cell traction may regulate angiogenesis.

\section{b. ECM Remodeling and Pattern Formation}

Fibroblasts, ECs, and a variety of other cell types distort and rearrange their surrounding ECM through traction forces as they move across them. ${ }^{275-278}$ For example, movement of fibroblasts through a collagen gel aligns the collagen fibers along the cell migration path, ${ }^{276}$ and the ECM beneath cultured ECs tends to align parallel to the long axis of the cell. ${ }^{279}$ This physical interaction between cells and the ECM 

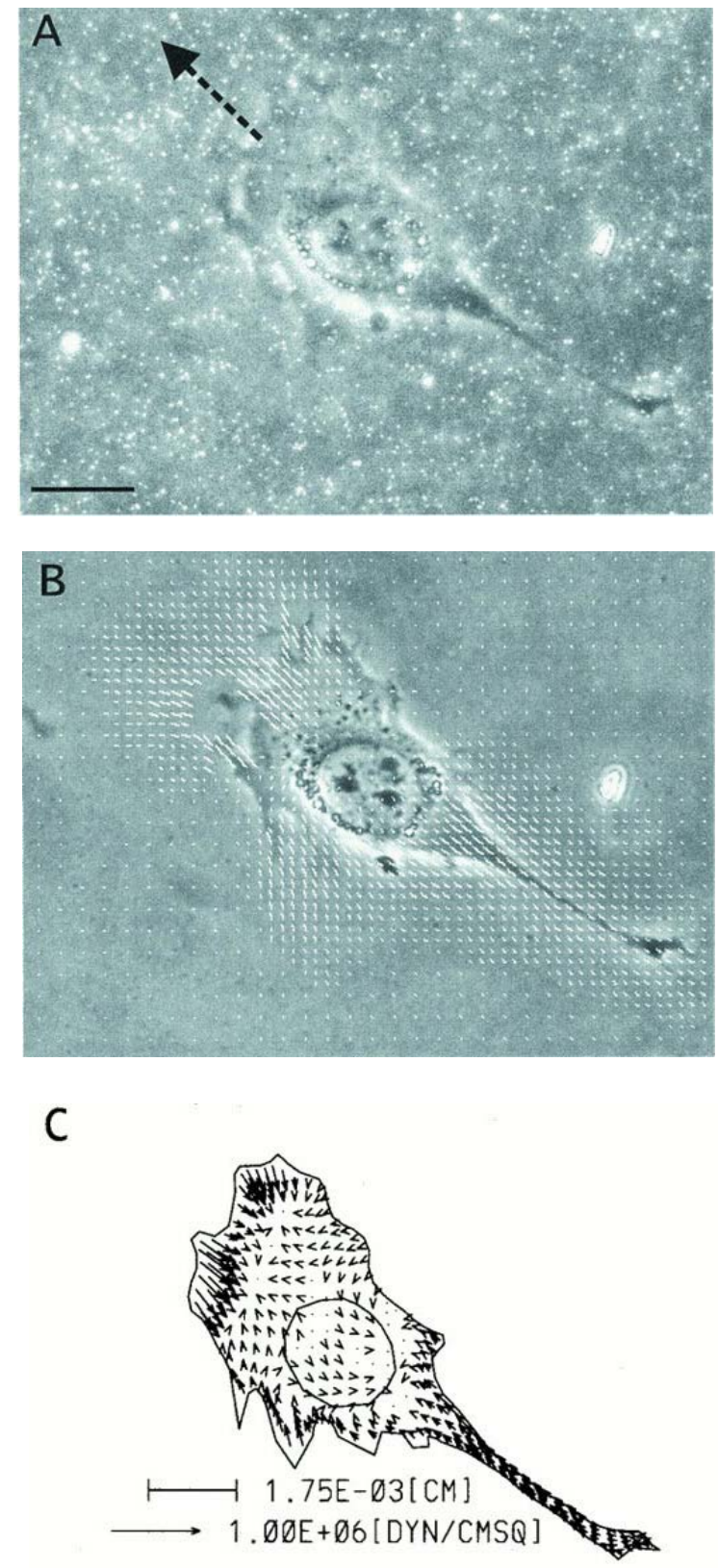

FIGURE 7. (opposite page) Traction maps of a migrating fibroblast obtained by the traction force microscopy technique. ${ }^{271}$ (A) An NIH 3T3 fibroblast was cultured on a polyacrylamide gel embedded with $0.2 \mu \mathrm{m}$-diameter fluorescent beads, which were used as markers for detecting substrate deformation. Traction stresses were then estimated based on the dis- 
is reciprocal in that an organized ECM can in turn affect the direction of migration or shape of the cells. It has been proposed that, during angiogenesis, traction forces applied by ECs at the sprouting tip may align the ECM, thereby forming a matrix pathway for trailing ECs. ${ }^{278}$ This hypothesis is supported by the "follow-the-leader" behavior exhibited by ECs during sprouting in vivo and in vitro ${ }^{278,280,281}$ and the formation of ECM "cables" that attach to and align in the axial direction of new EC tubes in vitro. ${ }^{282}$

Cells can exert strong traction forces that propagate and distort their surrounding ECM over a long distance. This aspect of cell traction is thought to play a role in facilitating the development of anastomoses between vascular sprouts, based on the similarity of matrix morphogenesis by fibroblasts and ECs. ${ }^{278}$ The pioneering work of Harris and colleagues ${ }^{276}$ in the early 1980s showed that when two pieces of chicken embryonic tissue containing fibroblasts were placed apart on a collagen gel, a dense tract of aligned collagen fibers developed between the two explants, presumably as a result of forces exerted by the fibroblasts on the collagen; the fibroblasts subsequently migrated out from the explants along the aligned collagen fibers. Subsequently, it was found that when suspended in collagen gels, aggregates of fibroblasts were connected by linear tracts of collagen fibers that aligned under the tensional stress exerted by fibroblasts. ${ }^{283}$ The patterns depended on cell population density and other factors. ${ }^{283}$ Overall, these findings provide evidence for a role of fibroblast tractions in matrix morphogenesis.

Similar phenomena have been observed in 3D and 2D angiogenesis assays. Korff and Augustin ${ }^{95}$ showed that when spheroidal aggregates of ECs (endothelial spheroids) were embedded in collagen gels, the collagen fibers between two adjacent spheroids were lined up along the axis connecting the two spheroids by the traction forces of ECs, and that endothelial sprouts from these spheroids grew directionally toward each other along these aligned collagen fibers (F1g. 8A). These investigators demonstrated further that tensional forces on a collagen gel are sufficient to guide directional outgrowth, although a possible role of paracrine signaling (e.g.,

placement of the beads. The image was recorded with simultaneous illumination for phase contrast and epi-fluorescence. Arrow indicates the direction of cell migration. Bar $=20 \mu \mathrm{m}$. The Young's modulus of the gel was $2.8 \times 10^{5} \mathrm{dyn} / \mathrm{cm}^{2}$. (B) Deformation vectors plotted over the phase image of the cell. Deformation was determined by comparing the distribution of fluorescent beads before and after force relaxation (by detachment of the cell with trypsin). Regions devoid of vectors either contained few fluorescent beads or went out of focus as a result of traction. (C) Field of traction stresses shown as vectorial arrows within the boundary of the cell. (From Munevar et al. Biophys J 2001; 80:1744-57. Copyright@ 2001 by the Biophysical Society. Reproduced by permission.) 
cytokines released from neighboring endothelial spheroids) cannot be excluded. ${ }^{95}$ In 2D angiogenesis assays, comprehensive studies by Vernon and colleagues ${ }^{188,277}$ showed that ECs organized a sheet of ECM into a web-like network of thin cables connecting scattered EC aggregates; these thin cables then acted as a template on which a network of endothelial cords developed (Fig. 8B). Several groups have reported similar observations in 2D assays. ${ }^{205,284-286}$

Vernon and colleagues ${ }^{188,278}$ proposed that ECM patterning is guided by EC tractions, as in the case of fibroblast-mediated collagen morphogenesis. It is proposed that an aggregate of ECs acts as a "traction center," pulling the ECM toward itself and thus rendering the nearby ECM under tension. Tension within the ECM is enhanced when two adjacent traction centers tug on the same matrix (the two-center effect), which causes ECM fibers to align and form narrow tracks between the two traction centers (Fig. 9A). ${ }^{188,278}$ A planar field of traction centers will become connected by multiple two-center effects, forming a tessellated pattern that defines the
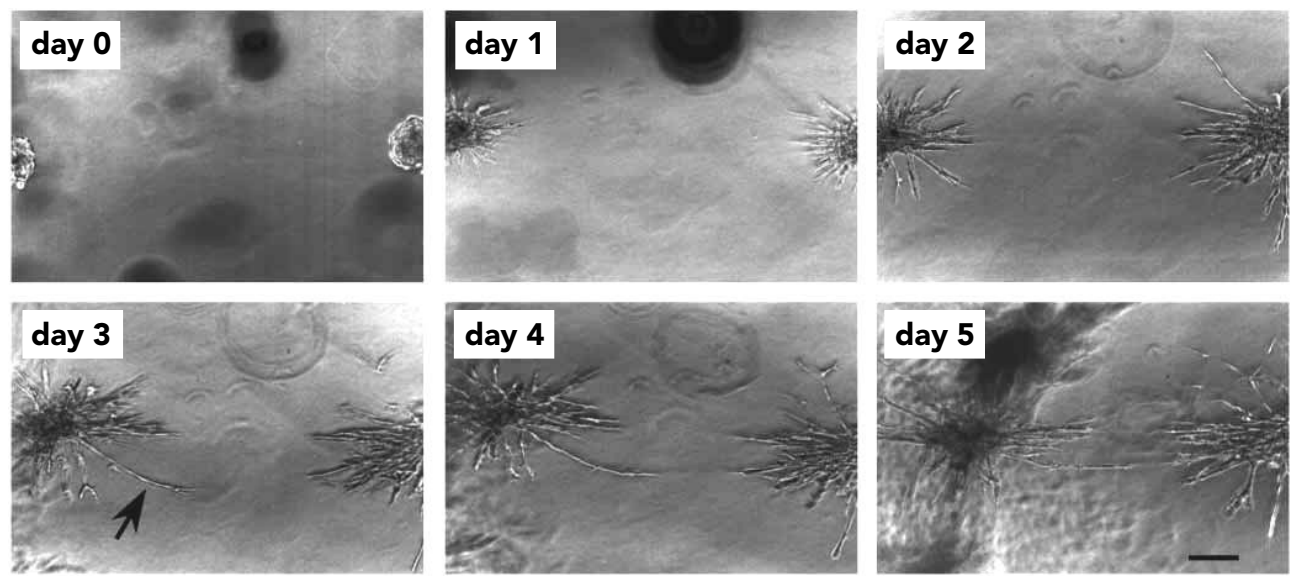

FIGURE 8A. Directional outgrowth of endothelial cells during the tube forming process. 3D angiogenesis assay. Two neighboring spheroidal aggregates of bovine aortic endothelial cells (endothelial spheroids) were embedded in a collagen gel with a distance of approximately $1.6 \mathrm{~mm}$ apart (measured from the center of each spheroid). Sprouts grew radially out of the spheroids for the first 2 days. After 3 days, capillary sprouts (arrow) started to change their direction to grow toward each other, which became even more evident after 4 and 5 days. Note that the centers of the two spheroids had become closer after 4 and 5 days, reflecting the traction forces exerted by the outgrowing endothelial cells. Bar $=200 \mu \mathrm{m}$. (From Korff and Augustin. J Cell Sci 1999; 112:3249-58. Copyright@ 1999 by the Company of Biologists. Reproduced by permission.) 
architecture of the capillary network. This two-center effect concept is also applicable in a 3D setting. ECs at the tips of adjacent sprouts would align the ECM between them by a traction-mediated two-center effect, approach one another via the matrix pathway, and fuse to form a common lumen (Fig. 9B). ${ }^{278}$

\section{c. Tubular Morphology}

Cell tractions also affect the shape of endothelial tubes in in vitro angiogenesis assays. It has been shown that tubular networks developed from ECs with weaker traction forces have shorter tubes but larger lumens and the tubes are less interconnected. ${ }^{287}$ The exact cause of these differences remains to be determined but is likely related to the capacity of cells to apply actin-myosin contractile forces for shaping the EC monolayer through cell-cell junctions and to generate traction forces for remodeling their surrounding ECM.

For morphogenetic processes that involve ECM remodeling, the ultimate matrix
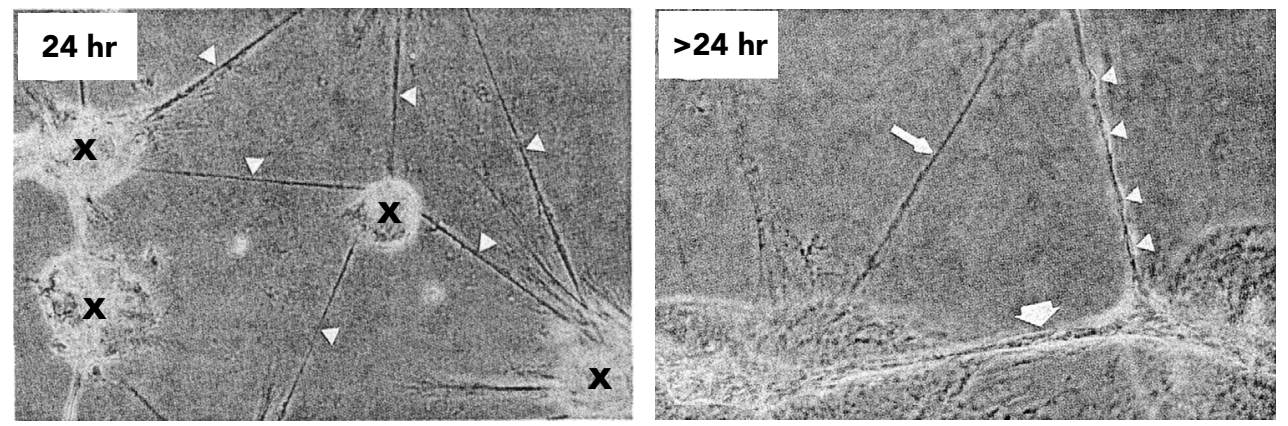

FIGURE 8B. Directional outgrowth of endothelial cells during the tube forming process. 2D angiogenesis assay. Left panel: after bovine aortic endothelial cells were cultured on a Matrigel gel for 24 hours, several cell aggregates (marked with " $x$ ") pulled and aligned nearby matrices into thin cables (arrowheads) connecting these aggregates. Right panel: three consequences of matrix reorganization by cells are shown here. One cable of matrix was cell-free (narrow arrow), whereas another cable bore individual cells (arrowheads) that connected to form an endothelial cell cord. Cells were forming a cord on a third cable (broad arrow). Images were viewed by phase-contrast at $120 \times$ magnification. (From Vernon et al. Lab Invest 1992; 66:536-47. (@) Nature Publishing Group [http://www.nature.com/]. Reprinted with permission.) 


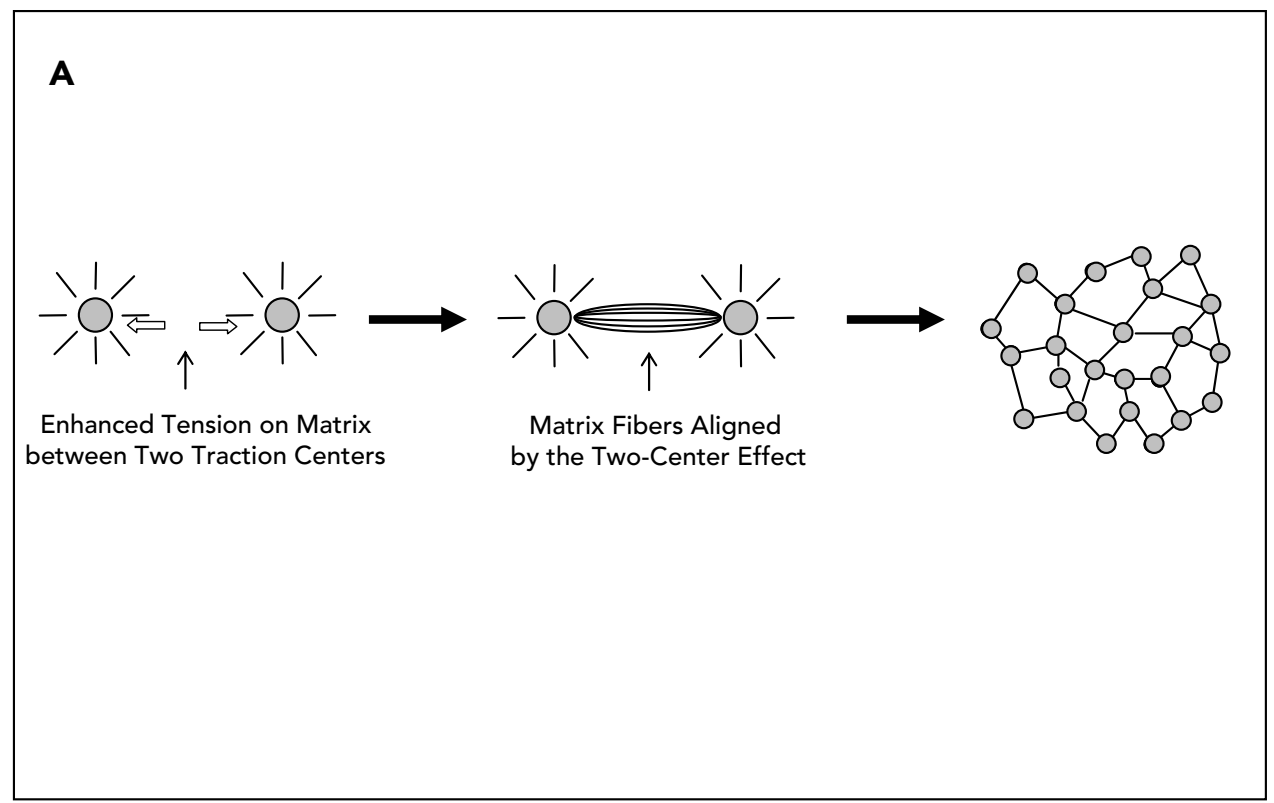

\section{B}

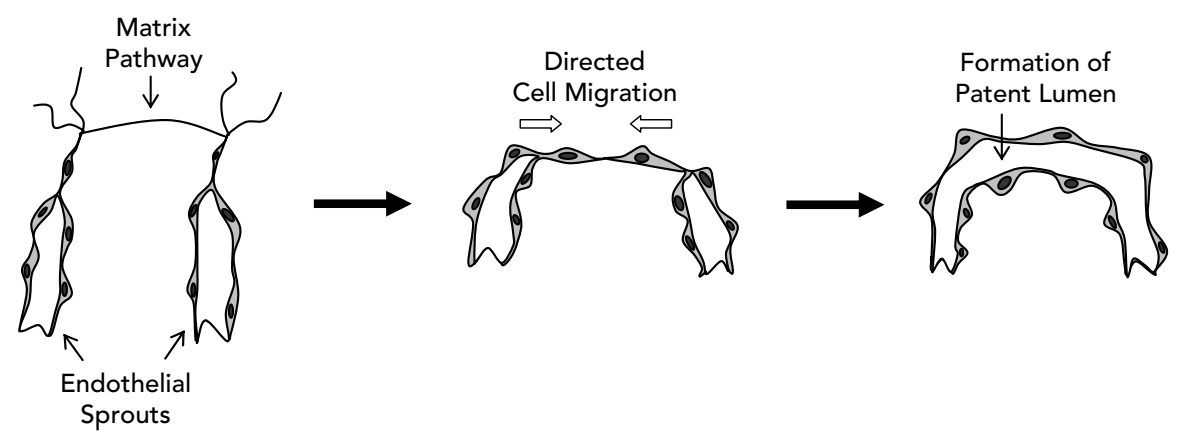

FIGURE 9. Traction-directed matrix remodeling. (A) Cell traction-guided matrix patterning in a $2 \mathrm{D}$ angiogenesis assay. Each of the two aggregates of endothelial cells acts as a "traction center" (gray circle), pulling the matrix toward itself and thus rendering the nearby matrix under tension. Tension within the matrix is enhanced when two adjacent traction centers tug on the same matrix (the two-center effect), which causes matrix fibers to align and form narrow tracks between the two traction centers. A planar field of traction centers 
reorganization depends on the balance between the traction forces exerted by the cells and the resistance of the ECM to these cellular forces. ${ }^{287,288}$ The bidirectional physical interaction between the cells and ECM is discussed in the next section.

\section{VI.B. Biomechanical Aspects of ECM Effects on Angiogenesis}

Although the effect of ECM molecules on cells is primarily mediated through integrins, ligand occupation alone is not sufficient to elicit a complete integrinmediated response unless the matrix proteins can physically resist tension. ${ }^{289,290}$ For example, in vitro studies have demonstrated that some early integrin signaling events in the cell cycle can be induced in suspended cells by allowing the cells to bind to ECM-coated microspheres; these cells, however, never enter $\mathrm{S}$ phase and may even undergo apoptosis. ${ }^{291-293}$ The tension-dependent control of cell growth is likely to ensure that only anchored cells can grow. Loss of this control (i.e., anchorage independence) is a hallmark of cancerous cells. ${ }^{292}$

While the chemical composition of the ECM determines whether or not a cell can bind to it, once ligation is established, the development of cytoskeletal tension is influenced by the ability of the ECM to resist tension. Generally, a rigid or larger surface can resist higher tension than a softer or smaller surface, respectively, thus enabling cells to carry more tension in the cytoskeleton. This notion has been verified by experimentation.

\section{Effects of Physical Properties of the ECM on Cell Traction}

\section{a. Effects of the Compliance of the ECM on Cell Traction}

Quantitative data relating substrate flexibility to traction forces were first obtained by Wang and colleagues. ${ }^{267,269}$ These investigators developed ECM-coated polyacrylamide substrata that allow the compliance to be varied while maintaining a

will become connected by multiple two-center effects, forming a tessellated pattern that defines the architecture of the capillary network. (B) Hypothetical role of matrix pathways in the development of anastomoses between vascular sprouts in a 3D setting. Endothelial cells at the tips of adjacent sprouts would align the matrix between them by a tractionmediated two-center effect, approach one another via the matrix pathway, and fuse to form a common lumen. (Adapted from Vernon and Sage. Am J Pathol 1995; 147:873-83, ${ }^{278}$ with permiission. (C) The American Journal of Pathology, published by the American Society for Investigative Pathology.) 
constant chemical environment for cell culture. Cellular traction forces were then deduced from the deformation of polyacrylamide substrata. ${ }^{267,269}$ When compared with rigid substrata, fibroblasts grown on soft substrata exert smaller traction forces, indicating a decrease in their intracellular tension (F1g. 10A). ${ }^{267}$ This response to soft substrata is accompanied by a decrease in the cell spreading area, a decrease in the rate of DNA synthesis, and an increase in the rate of apoptosis. Furthermore, treatment of cells on firm substrata with myosin inhibitors renders cell behavior similar to cells on extremely soft substrata (without inhibitor treatment). Similar phenomena have also been observed in $3 \mathrm{D}$ cell cultures using stabilized and freely floating collagen gels (i.e., stressed vs. relaxed gels). Fibroblasts grown in stabilized gels develop stress fibers and generate isometric tension within the gels, while those cultured on freely floating gels do not. ${ }^{294}$

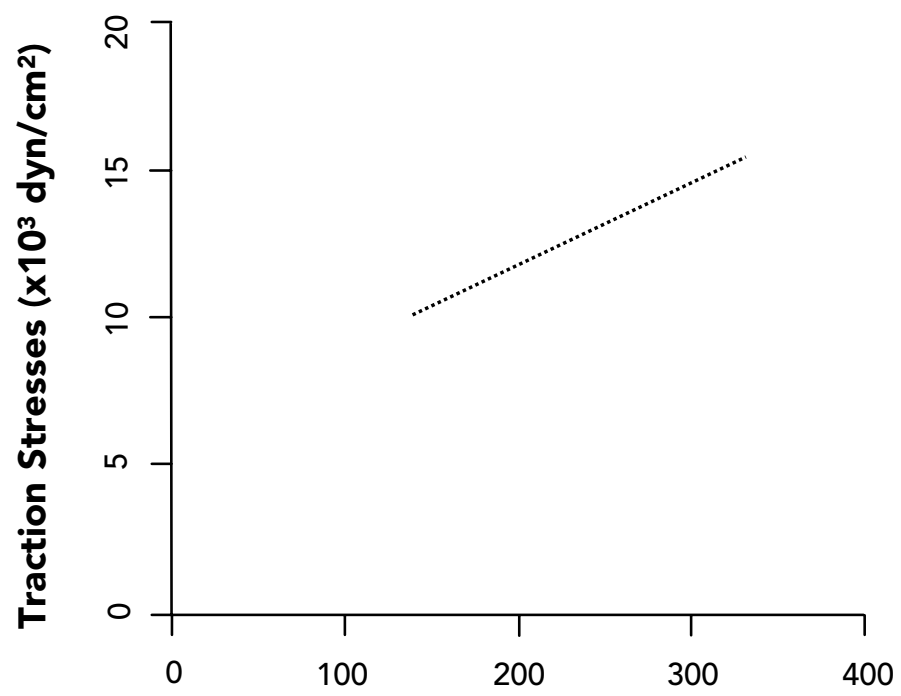

\section{Young's Modulus of the Substrate $\left(\times 10^{3} \mathrm{dyne} / \mathrm{cm}^{2}\right)$}

FIGURE 10A. Effects of physical properties of the extracellular matrix on traction stresses. Cells were cultured on polyacrylamide gels embedded with $0.2 \mathrm{~mm}$-diameter fluorescent beads. Cellular traction stresses were estimated based on the displacement of the beads, as shown in Fig. 7. The overall level of traction stresses (i.e., the average of the magnitude of traction stresses across the entire projected cell area) is reported here. (A) NIH 3T3 fibroblasts were cultured on collagen-coated polyacrylamide gels with different stiffness. Cells exerted larger traction stresses on stiffer than softer gels. (Reprinted with permission from Wang HB et al. Substrate flexibility regulates growth and apoptosis of normal but not transformed cells. Am J Physiol Cell Physiol 2000; 279:C1345-50. (The American Physiological Society.) 


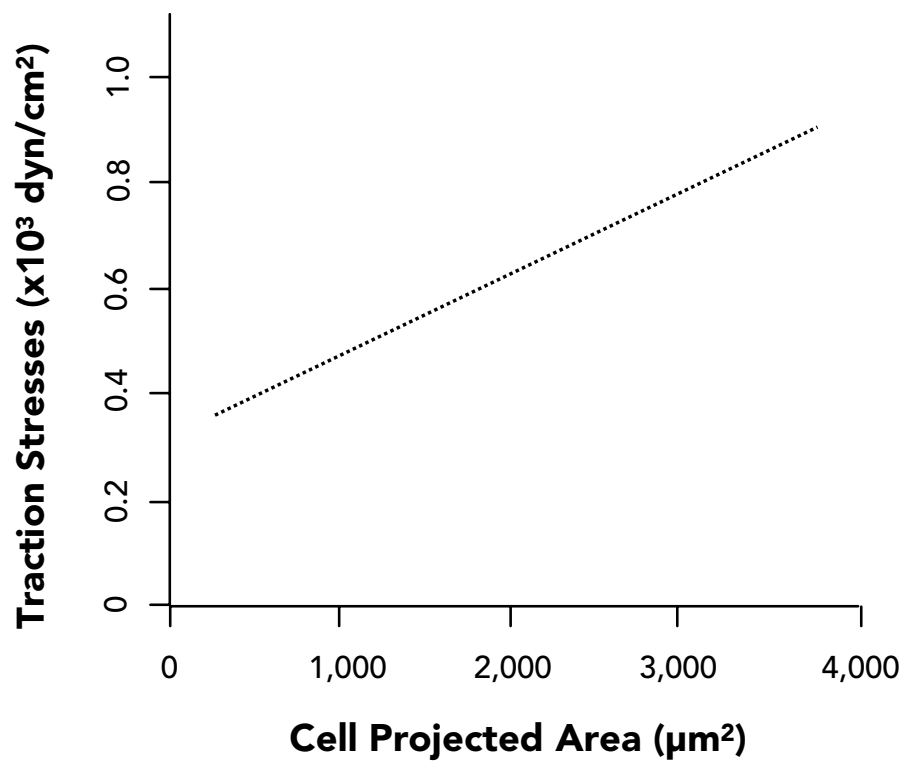

FIGURE 10B. Human airway smooth muscle cells were cultured on various micro-sized adhesive islands on the surface of polyacrylamide gels. The Young's modulus of the gels was $1.3 \times 104 \mathrm{dyn} / \mathrm{cm}^{2}$. Promoting cell spreading resulted in increased traction stresses. (Based on Wang et al. Cell Motil Cytoskeleton 2002; 52:97-106, ${ }^{296}$ with permission of Wiley-Liss, Inc., a subsidiary of John Wiley \& Sons, Inc.)

The above findings and a growing list of similar observations demonstrate the ability of cells to sense substrate flexibility and respond accordingly, most likely by applying contractile forces to the substrate via adhesion sites and then responding to the feedback (i.e., counterforces from the substrate) via the same sites. Hence, cell/substrate adhesion sites may act as mechano-probing devices, translating "external" mechanical input into intracellular signals. ${ }^{267,269}$ Several lines of experimental evidence strongly support a pivotal role for integrin-mediated adhesions in the mechanosensing process. . $^{10,227,234,241,242,295}$

\section{b. Effects of Spatial Distribution of ECM Ligands on Cell Traction}

The study of the relationship between cell area and cell traction has been based mostly on measuring the deformation of polyacrylamide substrata coated with different ECM density or different sizes of adhesion islands to control cell area. In general, a higher ECM (or ECM-derived peptide) coating density allows cells to 
spread better and form more FAs than a lower coating density. In the micropatterning approach, the polyacrylamide substrata are stamped with different micron-sized islands containing the same ECM density and surrounded by nonadhesive regions to constrain cell spreading. ${ }^{296}$ Studies using either approach have reached the same conclusion: regardless of peptide density, large well-spread cells tend to generate stronger traction forces (F1g. 10B). ${ }^{266,296}$ These results indicate that larger cells carry greater cytoskeletal tension and demonstrate that it is the extent of cell spreading, rather than ECM density, that influences cell tension.

It has been shown that myosin II-driven tension promotes cell spreading and that cell spreading stimulates MLC phosphorylation, thereby further increasing cytoskeletal tension. ${ }^{296,297}$ Hence, there is an intimate crosstalk between the generation of cytoskeletal tension and the extent of cell distortion, the latter being restricted by the ECM area that is available for cell attachment.

\section{Effects of Physical Properties of ECM on Angiogenesis}

\section{a. Effects of Compliance of ECM on Angiogenesis}

The potential of ECs to develop tubular networks is inversely related to the stiffness of the ECM scaffolds on which the cells reside (Table 2). In 2D angiogenesis assays, the development of planar networks on the surface of gels made of collagen, gelatin, or Matrigel was inhibited when the stiffness of these gels was increased by glycosylation, by increasing their concentration, or by other strategies. ${ }^{188,277,298,299}$ Similarly, sprouting of ECs, rat microvessel fragments, or rat aortic rings in 3D angiogenesis assays was inhibited when the stiffness of the scaffold was increased by manipulating the concentration or polymerization conditions of the constituent protein or the size, shape, or boundary conditions of the scaffold. ${ }^{103,185,287,300,301}$

Previously, the pro-angiogenic effect of increased flexibility was thought to be related to the availability/density of ECM binding sites to cells or the accessibility of ECs to soluble angiogenic factors or nutrients, particularly in 3D settings. As the importance of tension-mediated ECM remodeling and patterning in angiogenesis has come to light, the pro-angiogenic effect of increased flexibility is likely attributed to the reduction of the ECM stiffness, which allows ECs to reorganize the ECM through traction forces during the tube-forming process. ${ }^{10,278}$ Indeed, it was shown in the late 1970s that the basement membrane at tips of newly formed capillary sprouts (and growing epithelial glands as well) becomes thinner as a result of high ECM turnover, ${ }^{63,302}$ suggesting that a more malleable environment is needed for angiogenesis. It appears, however, that the range of malleability has an upper limit. ECs cannot form tubes in very soft ECM gels because they contract 
TABLE 2. Effects of Physical Properties of the Extracellular Matrix on Angiogenesis

\begin{tabular}{|c|c|c|}
\hline Cell Type ${ }^{a}$ & Substrate & $\begin{array}{l}\text { Cell response to changes in physical } \\
\text { properties of substrate }\end{array}$ \\
\hline \multicolumn{3}{|c|}{ Effects of compliance of extracellular matrix } \\
\hline \multicolumn{3}{|c|}{$2 \mathrm{D}$ angiogenesis assays } \\
\hline BAEC & Type I collagen & $\begin{array}{l}\text { Decreased tube formation when collagen } \\
\text { concentration was increased }\end{array}$ \\
\hline HUVEC & Gelatin & $\begin{array}{l}\text { Gelatin was coated on polyacrylamide gels } \\
\text { Decreased tube formation when the rigidity of the } \\
\text { polyacrylamide gel was increased }{ }^{299}\end{array}$ \\
\hline BAEC & Matrigel & $\begin{array}{l}\text { Matrigel was coated on a rigid surface } \\
\text { Decreased tube formation when the thickness of } \\
\text { Matrigel was decreased }\end{array}$ \\
\hline HUVEC & Matrigel & $\begin{array}{l}\text { Decreased tube formation when stiffness was } \\
\text { increased by glycation of Matrigel }\end{array}$ \\
\hline \multicolumn{3}{|c|}{ 3D angiogenesis assays } \\
\hline HBOEC & Type I collagen & $\begin{array}{l}\text { Decreased tube formation when stiffness was } \\
\text { increased by constraining a floating gel }{ }^{287}\end{array}$ \\
\hline HUVEC & Type I collagen & $\begin{array}{l}\text { Decreased tube formation when collagen } \\
\text { concentration was increased } \\
\text { Decreased tube formation when stiffness was } \\
\text { increased by glycation of collagen }{ }^{300}\end{array}$ \\
\hline Rat aortic rings & Type I collagen & $\begin{array}{l}\text { Decreased tube formation when collagen } \\
\text { concentration was increased } 104,105\end{array}$ \\
\hline $\begin{array}{l}\text { Rat microvessel } \\
\text { fragments }\end{array}$ & Type I collagen & $\begin{array}{l}\text { Decreased tube formation when collagen } \\
\text { concentration was increased }\end{array}$ \\
\hline HUVEC & Type III collagen & $\begin{array}{l}\text { Decreased tube formation when collagen } \\
\text { concentration was increased }\end{array}$ \\
\hline BPAEC & Fibrin & $\begin{array}{l}\text { Decreased tube formation when stiffness was } \\
\text { increased by manipulating the polymerization } \\
\text { condition } 301\end{array}$ \\
\hline HUVEC & Fibrin & $\begin{array}{l}\text { Decreased tube formation when fibrin } \\
\text { concentration was increased } 286\end{array}$ \\
\hline \multicolumn{3}{|c|}{ Effects of distribution of extracellular matrix } \\
\hline \multicolumn{3}{|c|}{$2 \mathrm{D}$ angiogenesis assays } \\
\hline BAEC & $\begin{array}{l}\text { Alkylated } \\
\text { cellulose }\end{array}$ & $\begin{array}{l}\text { Tube formation occurred at higher } \\
\text { hydrophobicity }{ }^{422}\end{array}$ \\
\hline BCEC & Type IV collagen & $\begin{array}{l}\text { Tube formation occurred at intermediate } \\
\text { concentration of type IV collagen }{ }^{81}\end{array}$ \\
\hline BCEC & Fibronectin & $\begin{array}{l}\text { Tube formation occurred at intermediate } \\
\text { concentration of fibronectin }{ }^{81} \\
\text { Tube formation occurred on } 10-\mu \mathrm{m} \text { but not on } 30- \\
\mu \mathrm{m} \text { wide linear strips }{ }^{282}\end{array}$ \\
\hline
\end{tabular}

a Abbreviations of cell types. BAEC = bovine aortic endothelial cells; BCEC = bovine capillary endothelial cells; BPAEC = bovine pulmonary artery endothelial cells; $\mathrm{HBOEC}=$ human blood outgrowth endothelial cells; HUVEC = human umbilical vein endothelial cells. 
the gels excessively. ${ }^{287}$ In extremely soft ECM gels, cells may undergo apoptosis if they cannot develop a sufficient amount of tension that is necessary for shape stability and survival.

\section{b. Effects of Spatial Distribution of ECM Ligands on Angiogenesis}

When the distribution of the ECM on rigid surfaces (e.g., petri dishes or glass slides) was manipulated by ECM coating density or surface patterning, the tube formation of ECs occurred on those resulting in intermediate cell area (or cell traction) (Table 2). Ingber and Folkman ${ }^{81}$ found that when ECs were plated on rigid surfaces coated with different densities of type IV collagen or fibronectin, ECs formed tubes at intermediate concentrations of these matrix molecules; on the other hand, ECs were highly spread and formed a monolayer at high matrix concentrations but were round and apoptotic at low concentrations. Subsequent studies applied micropatterning techniques to constrain cell spreading on $10 \mu \mathrm{m}$ - or $30 \mu \mathrm{m}$-wide stripes. ECs on a $10 \mu \mathrm{m}$-wide stripe formed a tube containing a central lumen, but those on $30 \mu \mathrm{m}$ stripes did not, even though ECs were cultured in the same medium and both strips were coated with the same fibronectin density. ${ }^{282}$ These findings suggest that tube formation by ECs is dependent on the extent of cell spreading and cytoskeletal tension.

\section{Effects of Angiogenesis on Structural and Material Properties of ECM}

Angiogenesis produces an increase in vessel density, facilitating tissue growth and repair. ${ }^{67,303}$ However, given the relatively high levels of MMP expression during angiogenesis, ${ }^{207}$ it is possible that the process of angiogenesis alters the mechanical properties of the tissue in which the event is occurring. Alterations in the mechanical properties of the tissue ECM, and consequently tissue function, may result in feedback signals to the angiogenic ECs, modulating angiogenic activity. ${ }^{304,305}$ However, the molecular mechanisms and the manner in which the alterations affect ECM material properties are unknown. A better understanding of the relationship between angiogenic vessels and the mechanics of the tissue undergoing angiogenesis will provide the basis for improved control of tissue vascularization in both native tissues and engineered constructs.

As discussed in Section V, proteolysis associated with angiogenesis requires the expression of a number of MMPs that degrade the ECM. In vitro, contact of ECs with ECM components, especially type I collagen, induces synthesis of MMP-1 and -2. ${ }^{306-308}$ MMP-1 and -2 degrade different targets but may have 
cross-reactivity. ${ }^{309}$ MMP-2 primarily lyses the basement membrane-types IV and V collagen, elastin, and laminin; while MMP-1 lyses the interstitium-types I and III collagen. ${ }^{310,311} \mathrm{MMP}-13$ and -9 are similar to MMP-1 and -2, respectively, with demonstrated differential temporal rates of expression and possible different sites of lysis. ${ }^{309,311}$

In vitro studies using a $3 \mathrm{D}$ intact microvessel angiogenesis system ${ }^{103}$ sup- $^{-}$ port the notion that MMP expression during angiogenesis can alter the material properties of the ECM. ${ }^{312,313}$ Changes in MMP gene expression and mechanical properties of 3D vascularized collagen gels were examined at two culture periods using quantitative PCR (qPCR) and viscoelastic materials testing, ${ }^{314}$ respectively. Six vascularized gels were tested at day 1 and day 6 of culture, while six native gels (no vessels) each were polymerized from the same collagen and tested at the same times. Twelve additional vascularized gels were used for qPCR at day 1 and day 6 of culture. Gene expression was quantified for MMP-2, -9, and -13. Expression levels for MMP targets were normalized to the geometric mean of the expression levels of four housekeeping genes (YWHAZ, GAPDH, UBC, and Dynactin). ${ }^{315}$ Results demonstrated a greater than $50 \%$ reduction in dynamic stiffness of the vascularized constructs between day 1 and day 6 of culture (Fig. 11). This period also corresponded in an approximately 50\% increase in expression of MMP-2 and -9 and an approximately $400 \%$ increase in MMP-13 (F1g. 12). In particular, there was a significant increase in relative expression levels for MMP-2, -9, and -13 between day 1 and day $6(p<0.001, p=0.004$, and $p=0.001$, respectively). In this angiogenesis model, day 6 corresponded to the appearance of the maximum number of new vessel sprouts, suggesting that the decrease in dynamic stiffness was due to MMP expression associated with new sprout formation.

Although these data are only correlative, the results point to MMP-mediated ECM degradation, specifically via MMP-13, as a potentially significant byproduct of angiogenesis. This phenomenon may have important implications for soft tissue healing, in which there is likely a tradeoff between the amount of angiogenesis necessary for tissue repair and compromise of the ECM material properties. As discussed in the previous sections, it is clear that ECM material properties play a role in regulating the proliferation of ECs. However, additional ECM physical properties such as density could modulate EC sprouting and invasion in angiogenic vessels, in that MMP expression could be insufficient to degrade the ECM locally. Clearly, further research in this area is warranted.

\section{VI.C. Role of Externally Applied Mechanical Stresses in Angiogenesis}

Blood vessels are constantly exposed to mechanical forces that originate from blood 


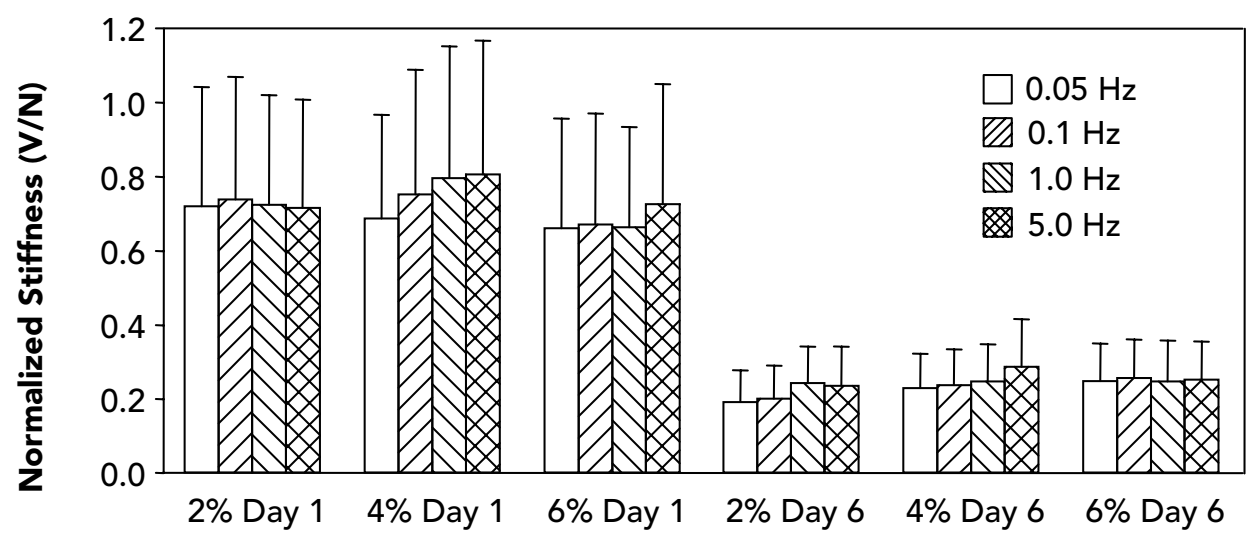

Equilibrium Strain Level and Day of Testing

FIGURE 11. Effect of angiogenesis on the mechanical properties of the ECM. Freshly isolated rat microvessel fragments were cultured in type I collagen gels as previously described. ${ }^{103}$ The dynamic stiffness of the vascularized gels was determined by viscoelastic materials testing at different culture periods ( 1 and 6 days), equilibrium strain level $(2,4$, and $6 \%$ ), and oscillation frequency $(0.05,0.1,1.0$, and $5.0 \mathrm{~Hz}){ }^{314}$ Data for each vascularized gel (V) were normalized by the corresponding native gel $(N)$. There was a significant decrease in dynamic stiffness between day 1 and day 6 for all tested conditions $(p<0.001)$. In contrast, there was no change in the dynamic stiffness of the native gels between test days. Data are shown as mean \pm standard deviation, $n=6$ for all bars.

flow or the extravascular environment such as compression by growing tissues or contracting skeletal muscle (Fig. 13). ${ }^{11}$ There is a vast amount of experimental evidence demonstrating that externally applied mechanical stresses (fluid shear stress, stretch, and pressure) regulate cytoskeletal organization, signal transduction, gene expression, and a wide variety of EC functions, including migration, proliferation, and ECM remodeling, which suggests a role of extrinsic stresses in angiogenesis. In fact, many studies have shown that fluid shear stress and stretch can affect the production and/or activity of the endogenous biochemical factors discussed in Section $\mathrm{V}$, although most of these investigations were not conducted in the context of angiogenesis. Several excellent reviews concerning the myriad effects of externally applied mechanical stresses on EC functions are available. ${ }^{24,316-326}$ Here our discussion is focused on findings that directly relate extrinsic stresses to the tube formation of ECs. 


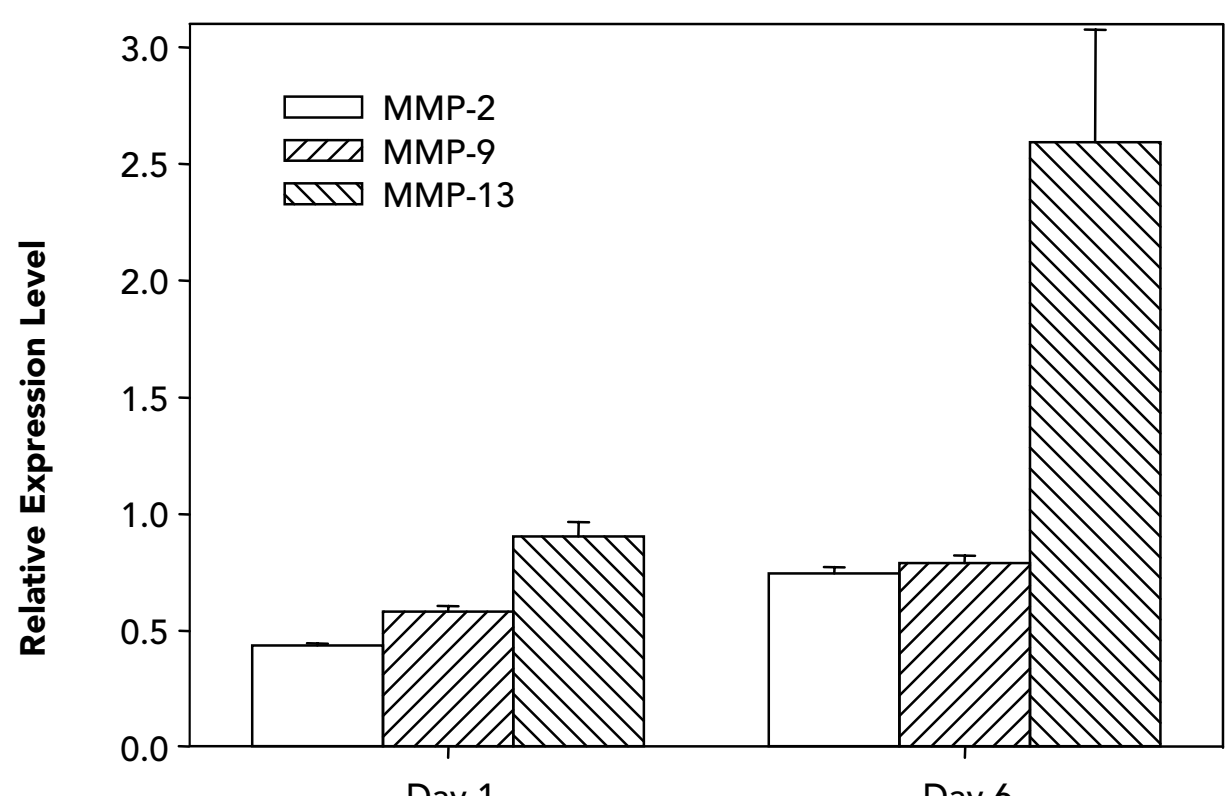

Day 1

Day 6

FIGURE 12. Temporal profile of MMP expression for the 3D intact microvessel angiogenesis system. Freshly isolated rat microvessel fragments were cultured in type I collagen gels as previously described. ${ }^{103}$ The mRNA amounts of MMPs-2, -9 , and -13 in the vascularized gels were examined at two culture periods using quantitative PCR. ${ }^{312,313}$ Expression was normalized to the geometric mean of four housekeeping genes (YWHAZ, GAPDH, UBC, Dynactin). ${ }^{315}$ There was a significant increase in expression of all three targets as a function of culture time $(p<0.001, p=0.004$, and $p=0.001$, respectively). Increases in MMP-2 and -9 expression between day 1 and day 6 were approximately $50 \%$, while the increase in MMP-13 expression was approximately $400 \%$. Data are shown as mean \pm standard deviation, $n=6$ for all bars.

\section{Externally Applied Mechanical Stresses on ECs}

\section{a. Hemodynamic Stresses}

A unique feature of the vascular system is that the natural environment is mechanically dynamic as a result of blood flow. There is ample evidence that hemodynamic stresses play an important role in modulating normal and pathological EC functions, 


\section{Blood Flow}

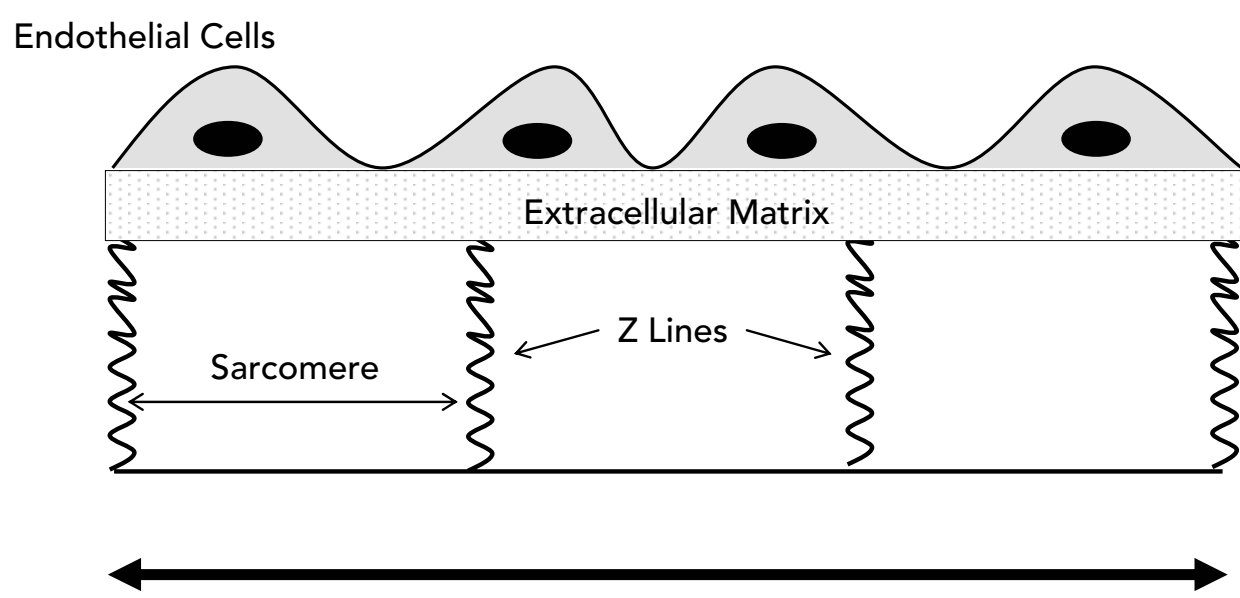

Muscle Stretch

FIGURE 13. Externally applied mechanical stresses on endothelial cells. Endothelial cells in a capillary may be subjected to mechanical stresses associated with blood flow (e.g., fluid shear stress acting on the luminal surface of ECs) or the muscle activity (e.g., muscle stretch acting on the basal surface of ECs). (C) 1998 Hudlicka O. Microcirculation 1998; 5:5-23. Adapted with permission of Taylor \& Francis Group, LLC, http://www.taylorandfrancis.com.)

although, historically, studies in this field have focused on ECs in large vessels in particular arteries. ${ }^{224,318,326}$ In the study of microvascular remodeling in response to hemodynamic stresses, investigations have focused primarily on wall shear stress, which results from the frictional drag caused by blood flowing over the EC surface (stationary wall), and circumferential wall stress, which results from a pressure gradient between the vessel lumen and exterior resulting from blood pressure. ${ }^{224,325,326}$

For laminar flow of an incompressible Newtonian fluid in a rigid tube with circular cross-section, the wall shear stress $\left(\tau_{w}\right)$ can be approximated from the blood velocity $(v)$ and the vessel lumen radius $(r)$, using:

$$
\tau_{w}=4 \mu f / \pi r^{3}=4 \mu v / r
$$

where $f$ is the volumetric blood flow rate and $\mu$ is the blood viscosity. 
The above equation has been used to estimate wall shear stress in both large and small vessels. ${ }^{11,325}$ However, as vessel diameter drops below $1 \mathrm{~mm}$, red blood cells cluster at the center of the vessel, resulting in a cell-free layer of plasma near the vessel walls (the Fahraeus-Lindqvist effect). ${ }^{226,327}$ This reduces the effective viscosity and thus results in lower shear stresses. In addition, in very small vessels such as capillaries, there is considerable interaction between circulating blood cells and ECs, including adhesive contact and/or friction, which can generate significant normal and shear stresses in these vessels. ${ }^{226,325,327}$ Nonetheless, Eq. (1) provides a convenient tool to estimate wall shear stress from parameters that can be acquired rather easily. The blood viscosity and lumen radius of capillaries are about 0.02 poise and $4 \mu \mathrm{m}$, respectively. The velocity of blood flow in capillaries usually refers to the red blood cell velocity $\left(v_{\mathrm{rbc}}\right)$ measured from intravital observation. ${ }^{11,327}$ As mentioned in Section II, the average flow velocity in the capillaries is approximately $1 \mathrm{~mm} / \mathrm{sec}^{13,14}$ Thus the wall shear stress in capillaries is on the order of $20 \mathrm{dyn} / \mathrm{cm}^{2}$.

The circumferential stress in ECs resulting from transmural pressure gradients from blood pressure can be estimated using the law of Laplace for an internally pressurized thin-walled cylinder,

$$
T=P r
$$

where $T$ is the wall tension per unit length and $P$ is the pressure difference across the vascular wall (intraluminal pressure - extravascular pressure).

The circumferential wall stress $\sigma$ (often referred to as the wall stress or hoop stress) can be derived from the tension using the relationship,

$$
T=\sigma h
$$

where $h$ is the wall thickness (endothelial thickness). ${ }^{226,325,327}$

If wall thickness is assumed to be $1 \mu \mathrm{m}$, the wall tension and wall stress are about $13.4 \mathrm{dyn} / \mathrm{cm}$ and $1.34 \times 10^{5} \mathrm{dyn} / \mathrm{cm}^{2}$, respectively, at a normal, resting capillary pressure $(25 \mathrm{mmHg}) .{ }^{14}$ This is perhaps the most accessible measure of wall stress. In reality, it is difficult to know the exact stress in capillaries because of problems associated with estimating the load-bearing wall thickness and support by external tissue, because the compliance of the capillaries depends on the amount of surrounding tissue that is integrated with the blood vessel and the state of stress in the surrounding tissue. ${ }^{226,325,327}$ 


\section{b. Extravascular Mechanical Factors}

In addition to blood-flow-associated stresses, blood vessels also experience extrinsic stresses originating from their surrounding tissues. For example, in the heart and skeletal muscles, muscle contraction produces compressive stresses that can effectively decrease vessel diameters and increase resistance to flow. ${ }^{11}$ Most of the investigations on microcirculation remodeling have been conducted using skeletal muscle. ${ }^{11}$ The circulation within skeletal muscle is highly organized. Capillaries generally run parallel to the muscle fibers (myocytes), with each fiber surrounded by 3 to 4 capillaries, depending on the type of muscle fiber. During muscle contraction, capillaries are exposed to repeated shortening and elongation as a result of changes in sarcomere length. Stretch of capillaries as a result of muscle activity is thought to be one of the several mechanisms by which exercise induces angiogenesis in skeletal muscle. ${ }^{11}$

\section{Effects of Externally Applied Mechanical Stresses on Angiogenesis}

Adult-derived mature ECs can develop capillary-like networks in cell culture in the absence of flow or any other externally applied stresses, ${ }^{69,70}$ demonstrating that extrinsic stresses are not necessary for angiogenesis; soluble angiogenic factors and the ECM together are sufficient. However, several different findings support the hypothesis that mechanical factors connected with blood flow or extravascular mechanical stretch are important regulators in postnatal physiological angiogenesis.

The role of blood flow in postnatal capillary growth was first demonstrated by Clark in the late 1910 s. $^{328}$ By examining capillaries in the same area in tadpole tails for many consecutive days, Clark was able to ascertain that capillaries with a high velocity of flow (and thus high shear stress) had more sprouts, but capillaries with slow flow gradually narrowed and disappeared. In agreement with this, several drugs known for their vasodilating properties were found to stimulate capillary growth in the heart and/or skeletal muscle after long-term administration (see Hudlicka ${ }^{11}$ for review). Observations that attest to a role of mechanical stretch in angiogenesis include the increased vascularity in healing skin flaps under stretch ${ }^{329}$ and exercise-induced angiogenesis via concomitant stretch of capillaries with muscle fibers, although the latter may also involve increased blood flow during exercise. ${ }^{11}$ Based on these observations, attempts have been made to present separately the evidence for the role of fluid shear stress and mechanical stretch in angiogenesis. These investigations are summarized in Table 3. 
TABLE 3. Effects of Fluid Shear Stress and Mechanical Stretch on Angiogenesis

\begin{tabular}{|c|c|c|}
\hline $\begin{array}{l}\text { Primary } \\
\text { stress }\end{array}$ & $\begin{array}{l}\text { Tissue or } \\
\text { cell type }\end{array}$ & Tissue or cell response to mechanical stimulation \\
\hline \multicolumn{3}{|c|}{ In vivo investigations } \\
\hline \multirow[t]{2}{*}{$\begin{array}{l}\text { Fluid shear } \\
\text { stress }\end{array}$} & $\begin{array}{l}\text { Rat } \\
\text { skeletal } \\
\text { muscle }\end{array}$ & $\begin{array}{l}\text { Increased capillary density in response to chronic } \\
\text { vasodilation } 330-335,337 \\
\text { Increased active form of MMP-9 in response to chronic } \\
\text { vasodilation } 332 \\
\text { Increased VEGF protein production and endothelial cell } \\
\text { proliferation in response to chronic vasodilation }\end{array}$ \\
\hline & $\begin{array}{l}\text { Rabbit ear } \\
\text { chamber }\end{array}$ & $\begin{array}{l}\text { Increased capillary density in response to chronic } \\
\text { vasodilation } 336\end{array}$ \\
\hline $\begin{array}{l}\text { Mechanical } \\
\text { stretch }\end{array}$ & $\begin{array}{l}\text { Rat } \\
\text { skeletal } \\
\text { muscle }\end{array}$ & $\begin{array}{l}\text { Increased capillary density in response to muscle } \\
\text { stretch }^{335,337-339} \\
\text { Increased MMP-2 activity, mRNA, and protein levels in } \\
\text { response to muscle stretch } 337 \\
\text { Increased MMP-14 mRNA level in response to muscle } \\
\text { stretch }^{337} \\
\text { Increased VEGF protein production and endothelial cell } \\
\text { proliferation in response to muscle stretch }\end{array}$ \\
\hline $\begin{array}{l}\text { Fluid shear } \\
\text { stress \& } \\
\text { mechanical } \\
\text { stretch }\end{array}$ & $\begin{array}{l}\text { Rat } \\
\text { skeletal } \\
\text { muscle }\end{array}$ & $\begin{array}{l}\text { Increased capillary density in response to chronic electric } \\
\text { stimulation } 335,340 \\
\text { Increased MMP-2 mRNA and protein levels in response to } \\
\text { chronic electric stimulation } 340 \\
\text { Increased MMP-14 mRNA and protein levels in response } \\
\text { to chronic electric stimulation } 340\end{array}$ \\
\hline \multicolumn{3}{|c|}{ In vitro investigations } \\
\hline \multirow[t]{2}{*}{$\begin{array}{l}\text { Fluid shear } \\
\text { stress }\end{array}$} & BAEC & $\begin{array}{l}\text { Directional assembly on Matrigel when subjected to shear } \\
\text { stress }^{345} \\
\text { Increased tube formation on Matrigel after subjected to } \\
\text { shear stress }{ }^{b, 423}\end{array}$ \\
\hline & BPMEC & $\begin{array}{l}\text { Increased tube formation in type I collagen gel when } \\
\text { subjected to shear stress } 352\end{array}$ \\
\hline $\begin{array}{l}\text { Mechanical } \\
\text { stretch }\end{array}$ & BAEC & $\begin{array}{l}\text { Directional outgrowth of endothelial sprouts when } \\
\text { cultured on stretched type I collagen gel }{ }^{c, 95}\end{array}$ \\
\hline Other & RCMEC & $\begin{array}{l}\text { Increased tube formation in type I collagen gel when } \\
\text { incubated with conditioned medium from stretched rat } \\
\text { cardiac myocytes } 353\end{array}$ \\
\hline
\end{tabular}

\footnotetext{
a Abbreviations of cell types. BAEC = bovine aortic endothelial cells; BPMEC = bovine pulmonary microvascular endothelial cells; RCMEC = rat coronary microvascular endothelial cells.

${ }^{b}$ Cells were subjected to fluid shear stress for 16 hours and then harvested for culture on Matrigel under static condition.

c No directional sprouting when cultured on stretched fibrin gels.
} 


\section{a. Effects of Fluid Shear Stress and Mechanical Stretch on Angiogenesis}

In vivo investigations. The role of fluid shear stress and mechanical stretch in postnatal capillary growth has been investigated primarily in rat skeletal muscle and rabbit ear chambers. Chronic administration of vasodilators, such as the $\alpha 1-$ adrenergic receptor antagonists (prazosin), dipyridamole, and propentofylline, is the most commonly used approach for achieving prolonged elevation of capillary shear stress without disturbing muscle contraction. ${ }^{11}$ Many studies using this approach have demonstrated conclusively that vasodilator-induced high shear stress caused a significant increase in the number of capillaries in rat skeletal muscle and rabbit ear chambers. ${ }^{330-337}$ Capillary growth in rat skeletal muscle can also be stimulated, with minimal alteration in blood flow, by stretching the muscle (e.g., overloading the extensor digitorum longus muscle by unilateral surgical removal of the tibialis anterior). ${ }^{335,337-339}$ Thus fluid shear stress and mechanical stretch can induce angiogenesis separately.

Comprehensive studies by Hudlicka and colleagues, ${ }^{335}$ however, show that the processes of shear- and stretch-induced capillary formation differ significantly. New capillaries in stretched muscle form primarily by sprouting angiogenesis, whereas shear stress stimulation causes capillary growth via intussusceptive angiogenesis. These distinct mechanisms seem to be additive in light of the fact that both forms of angiogenesis occurred in rat skeletal muscle subjected to chronic electrical stimulation (a treatment that induces muscle contraction and increases blood flow), although sprouting was the predominant mechanism. ${ }^{335}$ The finding that two angiogenic mechanisms can be initiated depending on the nature of the stimulus implies that the molecular events driving the process of angiogenesis differ with stimuli. In agreement with this, studies by Hass and colleagues ${ }^{340}$ show that inhibition of MMP activity eliminated the inductive effect of electric stimulation in capillary growth in rat skeletal muscle, and that the activity and mRNA of MMP-2 and mRNA of MMP-14 were increased during muscle stretch-induced but not shear stress-induced angiogenesis. ${ }^{337}$ Recall that ECM degradation is an essential element in sprouting angiogenesis. Taken together, these results are direct evidence that stimulation via muscle stretch (acting on the basal surface of ECs) and elevated shear stress (acting on the luminal surface of ECs) result in two distinct patterns of gene expression and EC behavior, leading to different angiogenic mechanisms (i.e., sprouting vs. intussusceptive angiogenesis).

The investigations summarized above examined the bulk change in capillary beds (e.g., numbers/density of capillaries) in response to a global change in the mechanical environment. At the cellular level, Hudlicka and colleagues ${ }^{11,341}$ noted that sprouts often occurred at the point of maximal curvature in preexisting capillaries (i.e., an area where the strain is high) in chronically stimulated muscle and suggested an 
increased protease activity in this region. This notion is supported by the findings of Hass and colleagues ${ }^{337,340}$ and a number of other reports demonstrating the inductive effect of strain on the production and/or activity of proteases. ${ }^{342,343}$

\section{b. Effects of Fluid Shear Stress and Mechanical Stretch on Angiogenesis}

In vitro investigations. The role of extrinsic stresses in angiogenesis has been investigated using 2D and 3D in vitro assays, as already discussed above, with modification to apply defined fluid shear stress or strain on cells. The effects of shear stress on the tube formation of ECs cultured on the surface of Matrigel or type I collagen gels have been studied using a parallel-plate flow chamber. ${ }^{344}$ Shear stress at $1 \mathrm{dyn} / \mathrm{cm}^{2}$ promoted the directional assembly of subconfluent bovine aortic ECs, which formed tubular structures that tended to align with flow direction on the surface of Matrigel. ${ }^{345}$ This finding is consistent with data in established literature showing that shear stress induces EC shape change such that the long axis of the cell body aligns with the direction of flow. ${ }^{346-351}$ In 3D cultures, the sprouting of a monolayer of bovine pulmonary microvascular ECs into collagen gels was enhanced by shear stress at 3 $\mathrm{dyn} / \mathrm{cm}^{2}$, but sprouts did not exhibit any directionality, presumably because of the minimal shear stress inside the gel. ${ }^{352}$

The effect of mechanical stretch on EC sprouting has been studied using 3D models in which tensional stresses are applied to ECM gels by uniaxial static stretch. When an EC spheroid was cultured on top of nonstretched collagen gels, sprouts grew radially out of the spheroid. However, when cultured on stretched collagen gels $(25,33$, and $50 \%$ elongation), outgrowth of ECs preferentially occurred along the direction of the tensional stresses in a dose-dependent manner. ${ }^{95}$ Tension-induced directional sprouting is primarily mediated through the tension-induced alignment of collagen fibers, which in turn support and guide EC outgrowth. The critical role of the matrix as a tension mediator is evidenced by the lack of directional sprouting of ECs cultured on stretched fibrin gels. ${ }^{95}$ When compared to collagen, fibrin forms much shorter fibers and has a more compact, dense structure, which appears to limit its mechanotransducing capability. ${ }^{95}$ Thus, when extrinsic stresses are applied to cells through the ECM, the mechanical and structural properties of the ECM affect how cells sense and/or respond to the external loading.

Finally, it is important to note that external loading, and stretch in particular, may activate ECs via paracrine signaling. Studies by Zheng and colleagues ${ }^{353}$ showed that cyclic stretch of rat cardiac myocytes $(10 \%$ strain, $0.5 \mathrm{~Hz})$ induced the release of VEGF from these cells. Furthermore, the tube formation of rat coronary microvascular ECs in 3D collagen gels was enhanced when ECs were incubated with conditioned medium from stretched rat cardiac myocytes, but it was inhibited 
when VEGF neutralizing antibodies were added to the conditioned medium. ${ }^{353}$ These findings suggest that stretch can indirectly evoke the tube formation of ECs via inducing the release of angiogenic stimuli from cardiac myocytes.

\section{Mechanotransduction}

There are numerous reports detailing the intracellular signaling events in ECs triggered by externally applied forces. Articles that provide comprehensive reviews in this subject are available. ${ }^{24,316-326}$ Generally speaking, the responses of ECs to extrinsic forces can be separated into rapid responses that occur within seconds to minutes and delayed responses that develop over many hours. ${ }^{224,321}$ The rapid responses are due to the activation of a variety of intracellular signaling events, including potassium channel activation, elevated intracellular free calcium concentration, inositol trisphosphate generation, adenylate cyclase activation, $\mathrm{G}$ protein activation, phosphorylation of protein kinases, and, eventually, activation of transcription factors. ${ }^{24,321}$ Delayed responses usually require the modulation of gene expression and may not occur if the mechanical stimulus is transient. ${ }^{224,321}$ Force-induced cytoskeletal rearrangement used to be considered a delayed response, because it may take hours for a cell to change its shape. With advances in microscopic imaging techniques that allow observations of cytoskeletal dynamics in a miniature time frame, it is now known that cytoskeletal reorganization in ECs occurs within seconds of mechanical stimulation. ${ }^{109,354}$

Although intracellular signaling events triggered by externally applied forces have been elucidated, the primary mechanosensor for transducing mechanical stimuli into biochemical signals remains elusive. It is hypothesized that forces may physically alter the molecular structure and/or displace the position of a sensor, thereby triggering chemical signal transduction events. Because most extrinsic forces first act directly on the plasma membrane, the majority of proposed mechanosensors are structures on the plasma membrane, including ion channels, $G$ protein-linked receptors, receptortype tyrosine kinases, integrins, and the lipid bilayer; alternatively, because forces applied to the plasma membrane are transferred to the cytoskeleton, it too could act as a mechanosensor. ${ }^{224,234,317,319,321,323,324,355-360}$ Of the proposed mechanosensors, cytoskeleton and integrins have been the most extensively studied.

As discussed in Section VI.A, an anchorage-dependent cell exists in a state of tension that is maintained by its cytoskeleton and balanced by the surrounding ECM via integrin-mediated adhesion sites. When an external force is applied to the cell, the internal cellular force changes to equalize the external force by actively rearranging its cytoskeleton and adhesion sites (that is, if the cell remains attached to the ECM). The resulting change in cytoskeletal tension may convey a regulatory 
signal to the cell and subsequently alter its functional state. Dynamic changes in cytoskeleton organization and cell/ECM linkages (e.g., the distribution and composition of FAs) may thus play a critical role in regulating mechanotransduction. These changes have been observed in ECs in responses to shear stress and stretch in in vitro studies. ${ }^{109,233,346,348,349,354,361-363}$

A central question remains as to how the cytoskeleton and/or adhesion complexes convert mechanical stresses to biochemical reactions. Located at the ECM/ transmembrane integrin/cytoskeleton linkage site, FA is a heterogeneous, multimolecular complex consisting of more than 50 different proteins. ${ }^{242,243}$ Enrichment of signaling and structural proteins at FAs could facilitate intracellular signaling by bringing enzymes and their substrates into close proximity, thereby enhancing the rate and opportunity of reaction. ${ }^{242,243,364} \mathrm{It}$ is hypothesized that forces exerted on integrins may induce structural modifications within the cell/ECM linkages, cell membrane, or cytoskeleton. ${ }^{227,242,272}$ These structural changes could in turn modulate the enzyme/substrate reactivity and/or the conductance of ion channels, thereby affecting signal transduction events. ${ }^{227,242,272}$ Alternatively, forces distributed along noncovalent bonds in a multimolecular FA complex may alter bond formation and dissociation kinetics, thereby altering signal transduction events. ${ }^{365,366}$

Finally, although each of the candidates mentioned above has been proposed to be a primary mechanosensor, it should be noted that they have a high degree of association with one another. ${ }^{224,321,366}$ Considering the diverse signaling pathways induced by forces, it is likely that several mechanosensors are induced simultaneously. Hence, forces may be transduced to biological signals through interactions of activated mechanoreceptors (Fig. 14). Such a "decentralized model" was proposed by Davies $^{224,367}$ to describe EC responses to mechanical stresses. In this model, forces acting on one region of the cell surface are also transmitted by the cytoskeleton to other locations at which signaling can occur, such as FAs at the cell/ECM interface, cell-cell junctions, membrane receptors on the apical surface, and the nuclear membrane; the cytoskeleton itself is also a mechanosensor. This model predicts mechanotransduction as an integrated response of multiple signaling networks that are spatially organized in the cell. There is an increasing amount of data supporting the decentralization model. ${ }^{224,227,321,367-369}$

\section{MATHEMATICAL MODELING OF BLOOD VESSEL FORMATION}

Mathematical modeling of angiogenesis has been a focus of research for over 20 years. The ability to predict the formation and growth of a vascular bed would provide an improved understanding of fundamental aspects of angiogenesis associated 


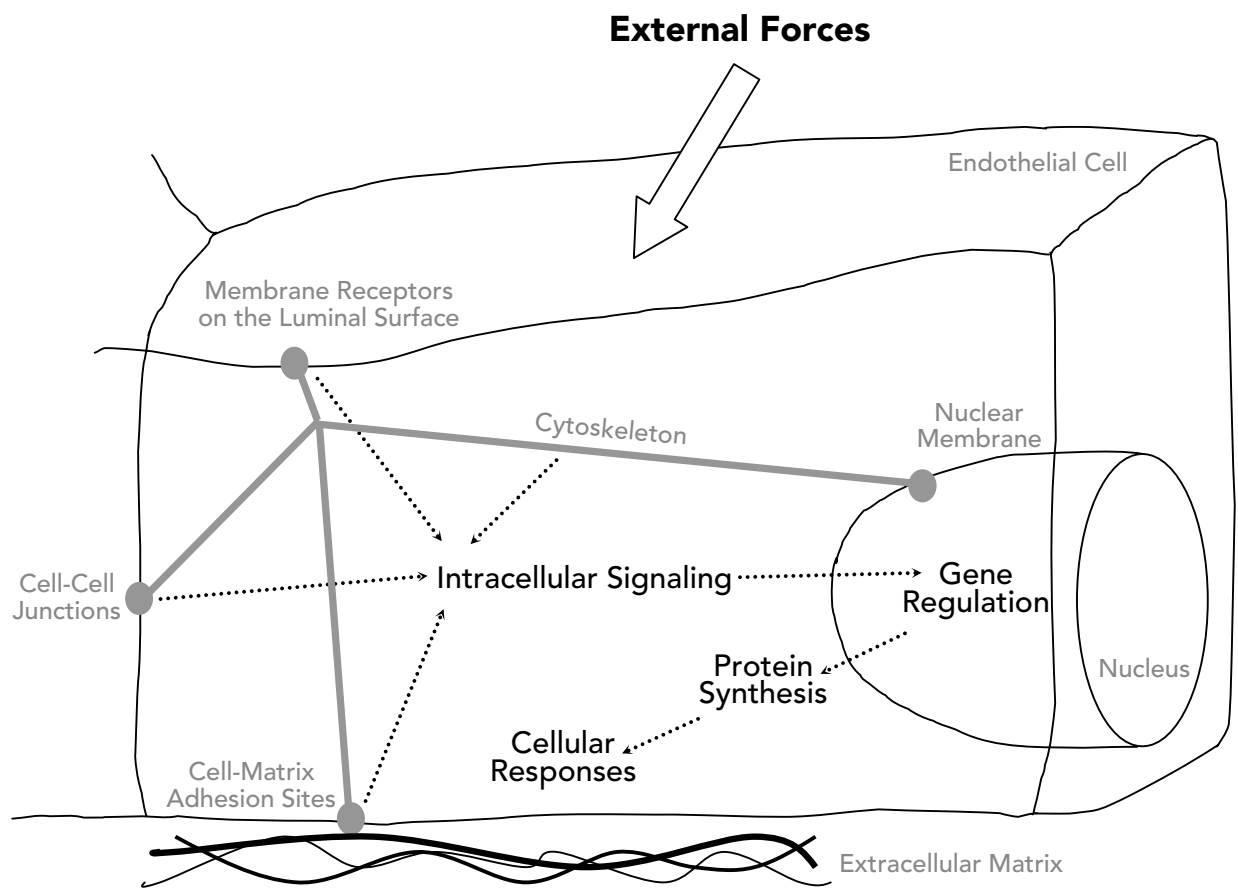

FIGURE 14. Mechanotransduction. Externally applied forces may directly activate individual mechanosensors or may be transmitted by the cytoskeleton to other locations where signaling can occur. In either case, cascades of intracellular signaling events are initiated, leading to altered gene expression and cell behavior. (Reprinted with permission from Davies PF. Flow-mediated endothelial mechanotransduction. Physiol Rev 1995; 75:519-60. ${ }^{224}$ @T The American Physiological Society.)

with wound healing and tumor metastasis, while potentially providing a framework for investigating treatment strategies to augment or inhibit angiogenesis. ${ }^{370}$ Most investigators have focused on the study of angiogenesis associated with tumor growth. ${ }^{371-384}$ In the case of solid tumors, continued growth of the tumor beyond a size of about 1-2 $\mathrm{mm}$ in diameter is diffusion limited, and the tumor must recruit a source of oxygen from the host vasculature via angiogenesis. While only one study explicitly addressed the prediction of angiogenesis associated with wound healing, ${ }^{385}$ many of the other mathematical frameworks that have been developed could be adapted to study wound healing. In all cases, the goal of the mathematical model is to predict the sprouting and growth of new vessels and/or branching/anastamosis in response to one or more stimulatory or inhibitory factors. This section focuses 
on the prediction of the growth of new vascular networks rather than the structural adaptation of existing vascular networks (such as in the work by Pries et al. ${ }^{386}$ ). For more details on the mathematical approaches used by previous investigators, the reader is encouraged to consult one of the available reviews in this area. ${ }^{370,387}$

\section{VII.A. Continuous Versus Discrete Approaches}

The methods that have been used to predict angiogenic sprouting and microvessel growth can be broadly categorized into continuous (or continuum) and discrete methods. Continuous methods use partial and ordinary differential equations (PDEs/ ODEs) to describe the variation of dependent variables in space and time. ${ }^{372,376,380-385}$ One of these equations is often based on conservation of EC mass and may be augmented by additional PDEs that govern diffusion/production of a chemical species or by the strong form of the equations of motion to incorporate the effects of ECM stresses. As an example, EC density commonly has been used as a dependent variable to track vascular growth. Continuous methods are generally deterministic.

The advantage of mathematical models that are based on continuous methods is that they benefit from the well developed mathematical and computational tools for solving PDEs and ODEs on continuous spatial domains, and they can be discretized with standard finite difference or finite element methods. The continuous approach has been used to model angiogenesis in both one dimension ${ }^{378,381-385,388}$ and two dimensions. ${ }^{288,376,378,380,389}$ Continuous models have been successful in predicting several features of angiogenesis, including EC density, EC growth rate, and the response of ECs to a variety of chemical and mechanical stimuli. However, they do not predict the actual morphological structure of the resulting vascular network.

Models that can be classified as discrete methods use a discrete approximation in terms of the state of cells, time evolution, and/or space. With discrete methods, the motion of individual ECs can be tracked over time, and the movement is generally based on a set of rules. One class of discrete models comprise the cellular automata models, ${ }^{390}$ which use the state of nearby cells in combination with a set of rules to control movement. Cellular automata models have a long history of use in mathematical modeling of angiogenesis ${ }^{377,391-398}$ and often incorporate stochastic ODEs. Discrete models can be combined with underlying continuous models. ${ }^{379,399}$

As an example of a discrete method, the movement of cells in the reinforced random walk mode ${ }^{371,400,401}$ is based on the state of a local signal that does not diffuse. The local probability density distribution of an EC at a spatial location is defined in terms of the transition probability rates at adjacent locations, which in turn are defined in terms of "control substances," which may include growth factors and/or ECM components. 
One of the major advantages of discrete methods is that they predict a distinct morphology for the vascular network. Furthermore, discrete methods generally use a smaller number of model inputs, and there is a wider range of input values that can give reasonable predictions of microvasculature structure and growth. Compared to models based on continuous PDEs, discrete models are computationally more efficient. However, the definition of the state space and the rules for transition are somewhat arbitrary, and there is always the question of whether or not distinct transitions between spaces exist in the actual biochemical and biophysical processes that occur.

\section{VII.B. Types of Angiogenic Stimuli}

\section{Chemotaxis}

Many of the mathematical models that have simulated angiogenesis in the context of tumor growth have examined chemotaxis resulting from either a generic tumor angiogenic factor (TAF) or more specific pro-angiogenic substances such as VEGF. $^{375-383,389,394-396,402}$ This approach has been used in both discrete and continuous models. Typically, the local rate of change of concentration of these substances is balanced with a diffusion-type term and a source/sink term. The local density of endothelial cells may then depend on the local concentration of one or more proand anti-angiogenic substances - for instance, angiostatin. ${ }^{371}$

This approach has been extended to include description of the time evolution of reaction in terms of products and inputs, most commonly using Michaelis-Menton kinetics. ${ }^{375,378,401,403,404}$

\section{Blood Flow}

Blood flow results in hemodynamic forces, and the resulting pressures and shear stresses on ECs have been proposed and modeled as angiogenic stimuli. ${ }^{374,399,405-407}$ The approaches are based on an ideal set-point for EC shear stress. For instance, Godde and Kurz ${ }^{399}$ modeled blood flow through capillary networks to determine local pressure gradients, which were in turn used to calculate local shear stress. A probability function was then computed based on the local shear stress and predefined minimum and maximum values of shear stress that would trigger either growth or regression of a microvessel. Such an approach can also be used to assess the concentration of blood-delivered substances such as oxygen ${ }^{399}$ or chemotherapeutic drugs. ${ }^{374}$ 


\section{Cell/ECM Interactions}

As discussed in Section VI, the physical/mechanical properties and spatial distribution of ECM components can have a dramatic effect on the proliferation and directional growth of ECs. In the absence of a tumor or blood flow, angiogenesis occurs "spontaneously" in many in vitro models. This is due to a number of factors, including hypoxia and cytokines in the media. In addition, cell/ECM interactions and mechanical stresses play a role. In mathematical models of angiogenesis, the effects of EC/ECM interactions have been incorporated using two approaches: (1) modeling haptotaxis, the directed movement of cell motility or outgrowth, either up or down a gradient of cellular adhesion sites ${ }^{376,377,379}$; and (2) modeling mechanotaxis, the influence of local EC-generated tractions on the movement (diffusion) of ECs. ${ }^{288,376,377,379,408,409}$

Haptotaxis has been simulated by using the local gradient of the density of ECM components such as fibronectin as a driving force for cell movement. $288,370,377,379,404$ The mathematical framework tracks the space- and time-varying concentration of the relevant haptotactic ECM component and bases a diffusive flux resulting from haptotaxis on its local gradient. If the concentration of the ECM component as a function of position $x$ and time $t$ is $c(x, t)$ and the local EC density is $n(x, t)$, the flux of ECs stemming from haptotaxis $J_{\text {haptotaxis }}$ can be represented as ${ }^{378}$

$$
J_{\text {haptotaxis }}=a(c) n \nabla c
$$

where $a(c)$ is a scaling coefficient that depends on the ECM component density.

This flux can be readily incorporated into any modeling framework that tracks ECM density as a primary dependent variable.

The role of EC-generated tractions in mechanotaxis during angiogenesis have been simulated using the framework of continuum mechanics. ${ }^{410}$ The strong form of the equations of motion ${ }^{411}$ defines the local balance of forces on the ECM. With the assumption of quasi-static equilibrium (no inertial forces), the equations of motion take the form

$$
\operatorname{div}(\sigma)+F=0
$$

Here, $\sigma$ is the second-order symmetric Cauchy stress tensor, and its divergence represents the internal forces per unit volume at a local point in the ECM; while $F$ is 
the external body force per unit volume. The Cauchy stress in the ECM is assumed to consist of stresses from the deformation of the ECM, $\sigma_{E C M}$, and stresses from traction forces applied by the ECs to the ECM, $\sigma_{E C}$ :

$$
\sigma=\sigma_{E C M}+\sigma_{E C}
$$

The material behavior of the ECM has been represented as a linear viscoelastic material, ${ }^{288,376}$ while the directionality of stresses resulting from EC contraction is generally ignored, and the ECs are assumed to generate a locally isotropic stress. The external force vector $F$ has been used to introduce a viscous drag term that depends on the relative velocity of the solid and fluid components of the ECM, analogous to the approach used in the biphasic theory. ${ }^{412-414}$ The mechanical stresses and strains are then related to the local concentration of ECs by assuming that the diffusion tensor is a function of the strains. ${ }^{288,376}$

\section{VII.C. Discussion}

Mathematical models of angiogenesis have examined mechanical interactions with the ECM using assumptions that are reasonable as a starting point, but some of the assumptions may oversimplify the physics. The most potentially limiting assumptions are the lack of detail on the morphology of ECs and the distribution of focal adhesions on ECs. The removal of the associated assumptions requires a much more detailed representation of the geometry of endothelial cells and potentially other cells such as pericytes. Furthermore, assumptions about the material behavior of the ECM have included the use of linear elastic and viscoelastic constitutive models, and these constitutive models are not objective (i.e., they are only valid for infinitesimal strains). A lack of directionality to the cell-generated traction forces in models of $\mathrm{EC} / \mathrm{ECM}$ interactions is questionable, because directional migration is an important characteristic of EC migration in vitro.

The validation of mathematical models of angiogenesis has been generally qualitative. Confidence in the predictive value of mathematical models is dependent on quantitative validation, and the most direct way to achieve such validation is through the use of specimen-specific modeling of in vitro systems. Imaging techniques such as volumetric confocal microscopy could provide the starting point in terms of geometry and cell classification. The prediction of in vitro sprouting and growth of angiogenic vessels, in the absence of tumor sources, would provide a solid foundation for further refinement of the models. 


\section{CONCLUDING REMARKS}

Angiogenesis is a complex process that involves numerous cellular, molecular, and biophysical regulators. Determining the spatial and temporal effects of these angiogenic regulators has far-reaching therapeutic possibilities and tissue engineering applications. This review has discussed the regulation of angiogenesis by diverse mechanical forces, including cell-generated forces and their counterforces from the ECM, externally applied forces that originate from blood flow and muscle activity, and extrinsic forces that are applied to ECs through the ECM. In the coming years, investigations should aim at understanding how cells integrate various chemical signals and mechanical cues, creating a coherent theory of the control of angiogenesis. In this regard, computational models that incorporate multiple epigenetic factors to predict capillary patterning will be useful.

\section{ACKNOWLEDGMENTS}

This work was supported by a Biomedical Engineering Research Grant \#RG-020133 from the Whitaker Foundation (YTS), NIH Grant \#R01 HL077683 (JAW), and NIH Grant \#HL67067 (JBH). The authors thank Ms. Karen Terry for help with manuscript preparation.

\section{REFERENCES}

1. Carmeliet P. Mechanisms of angiogenesis and arteriogenesis. Nat Med 2000; 6: 389-95.

2. Conway EM, Collen D, Carmeliet P. Molecular mechanisms of blood vessel growth. Cardiovasc Res 2001; 49:507-21.

3. Folkman J. Angiogenesis and angiogenesis inhibition: an overview. In: Goldberg ID, Rosen EM, editors. Regulation of Angiogenesis. Boston: Birkhauser, 1997.

4. Griffioen AW, Molema G. Angiogenesis: potentials for pharmacologic intervention in the treatment of cancer, cardiovascular diseases, and chronic inflammation. Pharmacol Rev 2000; 52:237-68.

5. Papetti M,Herman IM. Mechanisms of normal and tumor-derived angiogenesis. Am J Physiol Cell Physiol 2002; 282:C947-70.

6. Dimmeler S, Zeiher AM. Endothelial cell apoptosis in angiogenesis and vessel regression. Circ Res 2000; 87:434-9.

7. Carmeliet P. Manipulating angiogenesis in medicine. J Intern Med 2004; 255: 538-61. 
8. Sieminski AL, Gooch KJ. Biomaterial-microvasculature interactions. Biomaterials 2000; 21:2232-41.

9. Patel ZS, Mikos AG. Angiogenesis with biomaterial-based drug- and cell-delivery systems. J Biomater Sci Polym Ed 2004; 15:701-26.

10. Ingber DE. Mechanical signaling and the cellular response to extracellular matrix in angiogenesis and cardiovascular physiology. Circ Res 2002; 91:877-87.

11. Hudlicka $\mathrm{O}$. Is physiological angiogenesis in skeletal muscle regulated by changes in microcirculation? Microcirculation 1998; 5:5-23.

12. Ingber DE. Mechanobiology and diseases of mechanotransduction. Ann Med 2003; 35:564-77.

13. Moffett D, Moffett S, Schauf C. Human Physiology: Foundations and Frontiers. 2 ed. Dubuque, IO: WCB Publishers, 1993.

14. Berne RM, Levy MN. The cardiovascular system. In: Berne RM, Levy MN, editors. Physiology. 4 ed. St. Louis, MO: Mosby, 1998.

15. Florian JA, Kosky JR, Ainslie K, Pang Z, Dull RO, Tarbell JM. Heparan sulfate proteoglycan is a mechanosensor on endothelial cells. Circ Res 2003; 93:e136-42.

16. Sill HW, Chang YS, Artman JR, Frangos JA, Hollis TM, Tarbell JM. Shear stress increases hydraulic conductivity of cultured endothelial monolayers. Am J Physiol 1995; 268:H535-43.

17. Thi MM, Tarbell JM, Weinbaum S, Spray DC. The role of the glycocalyx in reorganization of the actin cytoskeleton under fluid shear stress: a "bumper-car" model. Proc Natl Acad Sci USA 2004; 101:16483-8.

18. Timpl R. Structure and biological activity of basement membrane proteins. Eur J Biochem 1989; 180:487-502.

19. Timpl R, Aumailley M. Biochemistry of basement membranes. Adv Nephrol Necker Hosp 1989; 18:59-76.

20. Yurchenco PD. Assembly of basement membranes. Ann NY Acad Sci 1990; 580: 195-213.

21. Yurchenco PD, O’Rear JJ. Basement membrane assembly. Methods Enzymol 1994; 245:489-518.

22. Yurchenco PD, Schittny JC. Molecular architecture of basement membranes. FASEB J 1990; 4:1577-90.

23. Sims DE. Diversity within pericytes. Clin Exp Pharmacol Physiol 2000; 27:842-6.

24. Baldwin AL, Thurston G. Mechanics of endothelial cell architecture and vascular permeability. Crit Rev Biomed Eng 2001; 29:247-78.

25. Dejana E, Bazzoni G, Lampugnani MG. The role of endothelial cell-to-cell junctions in vascular morphogenesis. Thromb Haemost 1999; 82:755-61.

26. Palade GE, Simionescu M, Simionescu N. Structural aspects of the permeability of the microvascular endothelium. Acta Physiol Scand Suppl 1979; 463:11-32.

27. Schnittler HJ. Structural and functional aspects of intercellular junctions in vascular endothelium. Basic Res Cardiol 1998; 93(Suppl 3):30-9.

28. Farquhar MG, Palade GE. Junctional complexes in various epithelia.J Cell Biol 1963; 17:375-412. 
29. Schneeberger EE, Karnovsky MJ. Substructure of intercellular junctions in freezefractured alveolar-capillary membranes of mouse lung. Circ Res 1976; 38:404-11.

30. Stevens T, Rosenberg R, Aird W, Quertermous T, Johnson FL, Garcia JG, Hebbel RP, Tuder RM, Garfinkel S. NHLBI workshop report: endothelial cell phenotypes in heart, lung, and blood diseases. Am J Physiol Cell Physiol 2001; 281:C1422-33.

31. Gonzalez-Crussi F. Vasculogenesis in the chick embryo. An ultrastructural study. Am J Anat 1971; 130:441-60.

32. Haar JL, Ackerman GA. A phase and electron microscopic study of vasculogenesis and erythropoiesis in the yolk sac of the mouse. Anat Rec 1971;170:199-223.

33. Kennedy M, Firpo M, Choi K, Wall C, Robertson S, Kabrun N, Keller G. A common precursor for primitive erythropoiesis and definitive haematopoiesis. Nature 1997; 386: 488-93.

34. Choi K. Hemangioblast development and regulation. Biochem Cell Biol 1998; 76: 947-56.

35. Choi K, Kennedy M, Kazarov A, Papadimitriou JC, Keller G. A common precursor for hematopoietic and endothelial cells. Development 1998; 125:725-32.

36. Witschi E. Development of Vertebrates. Philadelphia: Saunders, 1956.

37. Isogai S, Horiguchi $\mathrm{M}$, Weinstein BM. The vascular anatomy of the developing zebrafish: an atlas of embryonic and early larval development. Dev Biol 2001; 230: 278-301.

38. Schaper W, Ito WD. Molecular mechanisms of coronary collateral vessel growth. Circ Res 1996; 79:911-9.

39. Li DY, Brooke B, Davis EC, Mecham RP, Sorensen LK, Boak BB, Eichwald E, Keating MT. Elastin is an essential determinant of arterial morphogenesis. Nature 1998; 393:276-80.

40. Gridley T. Notch signaling during vascular development. Proc Natl Acad Sci USA 2001; 98:5377-8.

41. Iso T, Hamamori Y, Kedes L. Notch signaling in vascular development. Arterioscler Thromb Vasc Biol 2003; 23:543-53.

42. Burri PH, Hlushchuk R, Djonov V. Intussusceptive angiogenesis: its emergence, its characteristics, and its significance. Dev Dyn 2004; 231:474-88.

43. Jain RK, Schlenger K, Hockel M, Yuan F. Quantitative angiogenesis assays: progress and problems. Nat Med 1997; 3:1203-8.

44. Denekamp J. Vascular endothelium as the vulnerable element in tumours. Acta Radiol Oncol 1984; 23:217-25.

45. Schwartz SM, Benditt EP. Clustering of replicating cells in aortic endothelium. Proc Natl Acad Sci USA 1976; 73:651-3.

46. Hanahan D, Weinberg RA. The hallmarks of cancer. Cell 2000; 100:57-70.

47. Folkman J, Klagsbrun M. Angiogenic factors. Science 1987; 235:442-7.

48. Sandison JC. A new method for the microscopic study of living growing tissues by the introductin of a transparent chamber in the rabbit's ear. Anat Rec 1924; 28 : 281-87.

49. Ide AG, Baker NH, Warren SL. Vascilarization of the Brown-Pearce rabbit epithe- 
lioma transplant as seen in the transparent ear chamber. Am J Roentgenol 1939; 42: 891-99.

50. Patan S, Munn LL, Jain RK. Intussusceptive microvascular growth in a human colon adenocarcinoma xenograft: a novel mechanism of tumor angiogenesis. Microvasc Res 1996; 51:260-72.

51. Algire GH. An adaptation of the transparent chamber technique to the mouse. J Natl Cancer Inst USA 1943; 4:1-11.

52. Algire GH, Chalkley HW. Vascular reactions of normal and malignant tissues in vivo. I. Vascular reactions of mice to wounds and to normal and neoplastic transplants. J Natl Cancer Inst USA 1945; 6:73-85.

53. Leunig M, Yuan F, Menger MD, Boucher Y, Goetz AE, Messmer K, Jain RK. Angiogenesis, microvascular architecture, microhemodynamics, and interstitial fluid pressure during early growth of human adenocarcinoma LS174T in SCID mice. Cancer Res 1992; 52:6553-60.

54. Dellian M, Witwer BP, Salehi HA, Yuan F, Jain RK. Quantitation and physiological characterization of angiogenic vessels in mice: effect of basic fibroblast growth factor, vascular endothelial growth factor/vascular permeability factor, and host microenvironment. Am J Pathol 1996; 149:59-71.

55. Yuan F, Chen Y, Dellian M, Safabakhsh N, Ferrara N, Jain RK. Time-dependent vascular regression and permeability changes in established human tumor xenografts induced by an anti-vascular endothelial growth factor/vascular permeability factor antibody. Proc Natl Acad Sci USA 1996; 93:14765-70.

56. Clark ER, Kirby-Smith HT, Rex RO, Williams RG. Recent modifications in the method of studying living cells and tissues in transparent chambers inserted in the rabbit's ear. Anat Rec 1930; 47:187-211.

57. Endrich B, Intaglietta M, Reinhold HS, Gross JF. Hemodynamic characteristics in microcirculatory blood channels during early tumor growth. Cancer Res 1979; 39: 17-23.

58. Yamada S, Mayadas TN, Yuan F, Wagner DD, Hynes RO, Melder RJ, Jain RK. Rolling in $\mathrm{P}$-selectin-deficient mice is reduced but not eliminated in the dorsal skin. Blood 1995; 86:3487-92.

59. Auerbach R, Arensman R, Kubai L, Folkman J. Tumor-induced angiogenesis: lack of inhibition by irradiation. Int J Cancer 1975; 15:241-5.

60. Nguyen M, Shing Y, Folkman J. Quantitation of angiogenesis and antiangiogenesis in the chick embryo chorioallantoic membrane. Microvasc Res 1994; 47:31-40.

61. Sidky YA, Auerbach R. Lymphocyte-induced angiogenesis: a quantitative and sensitive assay of the graft-vs.-host reaction. J Exp Med 1975; 141:1084-100.

62. Lutz BR, Fulton GP, Patt DI, Handler AH. The growth rate of tumor transplants in the cheek pouch of the hamster. Cancer Res 1950; 10:231-32.

63. Ausprunk DH, Folkman J.Migration and proliferation of endothelial cells in preformed and newly formed blood vessels during tumor angiogenesis. Microvasc Res 1977; 14: $53-65$.

64. Sholley MM, Ferguson GP, Seibel HR, Montour JL, Wilson JD. Mechanisms of 
neovascularization. Vascular sprouting can occur without proliferation of endothelial cells. Lab Invest 1984; 51:624-34.

65. Muthukkaruppan V, Auerbach R. Angiogenesis in the mouse cornea. Science 1979; 205:1416-8.

66. Gimbrone MA Jr, Cotran RS, Leapman SB, Folkman J. Tumor growth and neovascularization: an experimental model using the rabbit cornea. J Natl Cancer Inst 1974; 52:413-27.

67. Risau W. Mechanisms of angiogenesis. Nature 1997; 386:671-4.

68. Shiu YT, McIntire LV. In vitro studies of erythrocyte-vascular endothelium interactions. Ann Biomed Eng 2003; 31:1299-313.

69. Folkman J, Haudenschild C. Angiogenesis by capillary endothelial cells in culture. Trans Ophthalmol Soc UK 1980; 100:346-53.

70. Folkman J, Haudenschild C. Angiogenesis in vitro. Nature 1980; 288:551-6.

71. Warren JB. Large vessel endothelial isolation. In: Warren JB, editor. The Endothelium: An Introduction to Current Research. New York: Wiley-Liss, 1980.

72. Karasek MA. Microvascular endothelial cell culture. J Invest Dermatol 1989; 93: 33S-8S.

73. Hewett PW, Murray JC. Human microvessel endothelial cells: isolation, culture and characterization. In Vitro Cell Dev Biol Anim 1993; 29A:823-30.

74. Carabasi RA,Williams SK,Jarrell BE. Cultured and immediately procured endothelial cells: current and future clinical applications. Ann Vasc Surg 1991; 5:477-84.

75. Pauly RR, Passaniti A, Crow M, Kinsella JL, Papadopoulos N, Monticone R, Lakatta EG, Martin GR. Experimental models that mimic the differentiation and dedifferentiation of vascular cells. Circulation 1992; 86:III68-73.

76. Scherberich A, Beretz A. Culture of vascular cells in tridimensional (3-D) collagen: a methodological review. Therapie 2000; 55:35-41.

77. Rupnick MA, Stokes CL, Williams SK, Lauffenburger DA. Quantitative analysis of random motility of human microvessel endothelial cells using a linear under-agarose assay. Lab Invest 1988; 59:363-72.

78. Staton CA, Stribbling SM, Tazzyman S, Hughes R, Brown NJ, Lewis CE. Current methods for assaying angiogenesis in vitro and in vivo. Int J Exp Pathol 2004; 85:233-48.

79. Vailhe B, Vittet D, Feige JJ. In vitro models of vasculogenesis and angiogenesis. Lab Invest 2001; 81:439-52.

80. Feder J, Marasa JC, Olander JV. The formation of capillary-like tubes by calf aortic endothelial cells grown in vitro. J Cell Physiol 1983; 116:1-6.

81. Ingber DE, Folkman J. Mechanochemical switching between growth and differentiation during fibroblast growth factor-stimulated angiogenesis in vitro: role of extracellular matrix. J Cell Biol 1989; 109:317-30.

82. Madri JA, Williams SK. Capillary endothelial cell cultures: phenotypic modulation by matrix components. J Cell Biol 1983; 97:153-65.

83. Kleinman HK, McGarvey ML, Liotta LA, Robey PG, Tryggvason K, Martin GR. Isolation and characterization of type IV procollagen, laminin, and heparan sulfate proteoglycan from the EHS sarcoma. Biochemistry 1982; 21:6188-93. 
84. Kubota Y, Kleinman HK, Martin GR, Lawley TJ. Role of laminin and basement membrane in the morphological differentiation of human endothelial cells into capillary-like structures. J Cell Biol 1988; 107:1589-98.

85. Maciag T, Kadish J,Wilkins L, Stemerman MB, Weinstein R. Organizational behavior of human umbilical vein endothelial cells. J Cell Biol 1982; 94:511-20.

86. Jackson CJ, Jenkins KL. Type I collagen fibrils promote rapid vascular tube formation upon contact with the apical side of cultured endothelium. Exp Cell Res 1991; 192: 319-23.

87. Jackson CJ, Jenkins K, Schrieber L. Possible mechanisms of type I collagen-induced vascular tube formation. EXS 1992; 61:198-204.

88. Chalupowicz DG, Chowdhury ZA, Bach TL, Barsigian C, Martinez J. Fibrin II induces endothelial cell capillary tube formation. J Cell Biol 1995; 130:207-15.

89. Schor AM, Schor SL, Allen TD. Effects of culture conditions on the proliferation, morphology and migration of bovine aortic endothelial cells. J Cell Sci 1983; 62: 267-85.

90. Montesano R, Orci L, Vassalli P. In vitro rapid organization of endothelial cells into capillary-like networks is promoted by collagen matrices. J Cell Biol 1983; 97 : 1648-52.

91. Montesano R, Orci L. Tumor-promoting phorbol esters induce angiogenesis in vitro. Cell 1985; 42:469-77.

92. Montesano R, Vassalli JD, Baird A, Guillemin R, Orci L. Basic fibroblast growth factor induces angiogenesis in vitro. Proc Natl Acad Sci USA 1986; 83:7297-301.

93. Madri JA, Pratt BM, Tucker AM. Phenotypic modulation of endothelial cells by transforming growth factor-beta depends upon the composition and organization of the extracellular matrix. J Cell Biol 1988; 106:1375-84.

94. Bayless KJ, Salazar R, Davis GE. RGD-dependent vacuolation and lumen formation observed during endothelial cell morphogenesis in three-dimensional fibrin matrices involves the alpha(v)beta(3) and alpha(5)beta(1) integrins. Am J Pathol 2000; 156: 1673-83.

95. Korff T, Augustin HG. Tensional forces in fibrillar extracellular matrices control directional capillary sprouting. J Cell Sci 1999; 112:3249-58.

96. Nicosia RF, Tchao R, Leighton J. Interactions between newly formed endothelial channels and carcinoma cells in plasma clot culture. Clin Exp Metastasis 1986; 4: 91-104.

97. Vernon RB, Sage EH. A novel, quantitative model for study of endothelial cell migration and sprout formation within three-dimensional collagen matrices. Microvasc Res 1999; 57:118-33.

98. Nehls V, Drenckhahn D. A microcarrier-based cocultivation system for the investigation of factors and cells involved in angiogenesis in three-dimensional fibrin matrices in vitro. Histochem Cell Biol 1995; 104:459-66.

99. Nehls V, Drenckhahn D. A novel, microcarrier-based in vitro assay for rapid and reliable quantification of three-dimensional cell migration and angiogenesis. Microvasc Res 1995; 50:311-22. 
100. Donovan D, Brown NJ, Bishop ET, Lewis CE. Comparison of three in vitro human 'angiogenesis' assays with capillaries formed in vivo. Angiogenesis 2001; 4:113-21.

101. Korff T, Kimmina S, Martiny-Baron G, Augustin HG. Blood vessel maturation in a 3-dimensional spheroidal coculture model: direct contact with smooth muscle cells regulates endothelial cell quiescence and abrogates VEGF responsiveness. FASEB J 2001; 15:447-57.

102. Arthur WT, Vernon RB, Sage EH, Reed MJ. Growth factors reverse the impaired sprouting of microvessels from aged mice. Microvasc Res 1998; 55:260-70.

103. Hoying JB, Boswell CA, Williams SK. Angiogenic potential of microvessel fragments established in three-dimensional collagen gels. In Vitro Cell Dev Biol Anim 1996; 32:409-19.

104. Nicosia RF, Ottinetti A. Modulation of microvascular growth and morphogenesis by reconstituted basement membrane gel in three-dimensional cultures of rat aorta: a comparative study of angiogenesis in matrigel, collagen, fibrin, and plasma clot. In Vitro Cell Dev Biol 1990; 26:119-28.

105. Nicosia RF, Ottinetti A. Growth of microvessels in serum-free matrix culture of rat aorta. A quantitative assay of angiogenesis in vitro. Lab Invest 1990; 63:115-22.

106. Nicosia RF, Tchao R, Leighton J. Histotypic angiogenesis in vitro: light microscopic, ultrastructural, and radioautographic studies. In Vitro 1982; 18:538-49.

107. Shepherd BR, Chen HY, Smith CM, Gruionu G, Williams SK, Hoying JB. Rapid perfusion and network remodeling in a microvascular construct after implantation. Arterioscler Thromb Vasc Biol 2004; 24:898-904.

108. Hoying JB, Williams SK. Effects of basic fibroblast growth factor on human microvessel endothelial cell migration on collagen I correlates inversely with adhesion and is cell density dependent. J Cell Physiol 1996; 168:294-304.

109. Li S, Butler P, Wang Y, Hu Y, Han DC, Usami S, Guan JL, Chien S. The role of the dynamics of focal adhesion kinase in the mechanotaxis of endothelial cells. Proc Natl Acad Sci USA 2002; 99:3546-51.

110. Li S, Bhatia S, Hu YL, Shiu YT, Li YS, Usami S, Chien S. Effects of morphological patterning on endothelial cell migration. Biorheology 2001; 38:101-8.

111. Shiu YT, Li S, Marganski WA, Usami S, Schwartz MA, Wang YL, Dembo M, Chien $\mathrm{S}$. Rho mediates the shear-enhancement of endothelial cell migration and traction force generation. Biophys J 2004; 86:2558-65.

112. Pratt BM, Harris AS, Morrow JS, Madri JA. Mechanisms of cytoskeletal regulation. Modulation of aortic endothelial cell spectrin by the extracellular matrix. Am J Pathol 1984; 117:349-54.

113. Hasson JE, Wiebe DH, Sharefkin JB, Abbott WM. Migration of adult human vascular endothelial cells: effect of extracellular matrix proteins. Surgery 1986; 100:384-91.

114. Hsu PP, Li S, Li YS, Usami S, Ratcliffe A, Wang X, Chien S. Effects of flow patterns on endothelial cell migration into a zone of mechanical denudation. Biochem Biophys Res Commun 2001; 285:751-9.

115. Stenn KS. Quantitative assay of dissociated tissue-cell motility in vitro. In Vitro 1980; $16: 357-60$. 
116. Sato Y, Rifkin DB. Autocrine activities of basic fibroblast growth factor: regulation of endothelial cell movement, plasminogen activator synthesis, and DNA synthesis. J Cell Biol 1988; 107:1199-205.

117. Boyden S. The chemotactic effect of mixtures of antibody and antigen on polymorphonuclear leucocytes. J Exp Med 1962; 115:453-66.

118. Hendrix MJ, Seftor EA, Seftor RE, Fidler IJ. A simple quantitative assay for studying the invasive potential of high and low human metastatic variants. Cancer Lett 1987; 38:137-47.

119. Repo H. Leukocyte migration agarose test for the assessment of human neutrophil chemotaxis. I. Effects of environmental factors on neutrophil migration under agarose. Scand J Immunol 1977; 6:203-9.

120. Wu P, Hoying JB, Williams SK, Kozikowski BA, Lauffenburger DA. Integrin-binding peptide in solution inhibits or enhances endothelial cell migration, predictably from cell adhesion. Ann Biomed Eng 1994; 22:144-52.

121. Houck KA, Leung DW, Rowland AM, Winer J, Ferrara N. Dual regulation of vascular endothelial growth factor bioavailability by genetic and proteolytic mechanisms.J Biol Chem 1992; 267:26031-7.

122. Robinson CJ, Stringer SE. The splice variants of vascular endothelial growth factor (VEGF) and their receptors. J Cell Sci 2001; 114:853-65.

123. Dvorak HF, Detmar M, Claffey KP, Nagy JA, van de Water L, Senger DR. Vascular permeability factor/vascular endothelial growth factor: an important mediator of angiogenesis in malignancy and inflammation. Int Arch Allergy Immunol 1995; 107:233-5.

124. Ferrara N. Role of vascular endothelial growth factor in the regulation of angiogenesis. Kidney Int 1999; 56:794-814.

125. Isner JM, Asahara T. Angiogenesis and vasculogenesis as therapeutic strategies for postnatal neovascularization. J Clin Invest 1999; 103:1231-6.

126. Dvorak HF. VPF/VEGF and the angiogenic response. Semin Perinatol 2000; 24: 75-8.

127. Connolly DT, Heuvelman DM, Nelson R, Olander JV, Eppley BL, Delfino JJ, Siegel NR, Leimgruber RM, Feder J. Tumor vascular permeability factor stimulates endothelial cell growth and angiogenesis. J Clin Invest 1989; 84:1470-8.

128. Gerber HP, McMurtrey A, Kowalski J, Yan M, Keyt BA, Dixit V, Ferrara N. Vascular endothelial growth factor regulates endothelial cell survival through the phosphatidylinositol 3'-kinase/Akt signal transduction pathway. Requirement for Flk-1/KDR activation. J Biol Chem 1998; 273:30336-43.

129. Esser S, Lampugnani MG, Corada M, Dejana E, Risau W. Vascular endothelial growth factor induces VE-cadherin tyrosine phosphorylation in endothelial cells. J Cell Sci 1998; 111:1853-65.

130. Kevil CG, Payne DK, Mire E, Alexander JS. Vascular permeability factor/vascular endothelial cell growth factor-mediated permeability occurs through disorganization of endothelial junctional proteins. J Biol Chem 1998; 273:15099-103.

131. Kohn S, Nagy JA, Dvorak HF, Dvorak AM. Pathways of macromolecular tracer 
transport across venules and small veins. Structural basis for the hyperpermeability of tumor blood vessels. Lab Invest 1992; 67:596-607.

132. Senger DR, Galli SJ, Dvorak AM, Perruzzi CA, Harvey VS, Dvorak HF. Tumor cells secrete a vascular permeability factor that promotes accumulation of ascites fluid. Science $1983 ; 219: 983-5$.

133. Dimmeler S, Dernbach E, Zeiher AM. Phosphorylation of the endothelial nitric oxide synthase at ser-1177 is required for VEGF-induced endothelial cell migration. FEBS Lett 2000; 477:258-62.

134. Pepper MS, Ferrara N, Orci L, Montesano R. Vascular endothelial growth factor (VEGF) induces plasminogen activators and plasminogen activator inhibitor-1 in microvascular endothelial cells. Biochem Biophys Res Commun 1991; 181:902-6.

135. Pepper MS, Ferrara N, Orci L, Montesano R. Potent synergism between vascular endothelial growth factor and basic fibroblast growth factor in the induction of angiogenesis in vitro. Biochem Biophys Res Commun 1992; 189:824-31.

136. Ziche M, Morbidelli L, Choudhuri R, Zhang HT, Donnini S, Granger HJ, Bicknell R. Nitric oxide synthase lies downstream from vascular endothelial growth factor-induced but not basic fibroblast growth factor-induced angiogenesis. J Clin Invest 1997; 99: 2625-34.

137. Takagi H, King GL, Ferrara N, Aiello LP. Hypoxia regulates vascular endothelial growth factor receptor KDR/Flk gene expression through adenosine A2 receptors in retinal capillary endothelial cells. Invest Ophthalmol Vis Sci 1996; 37:1311-21.

138. Stein I, Neeman M, Shweiki D, Itin A, Keshet E. Stabilization of vascular endothelial growth factor mRNA by hypoxia and hypoglycemia and coregulation with other ischemia-induced genes. Mol Cell Biol 1995; 15:5363-8.

139. Kimura H, Weisz A, Kurashima Y, Hashimoto K, Ogura T, D’Acquisto F, Addeo R, Makuuchi M, Esumi H. Hypoxia response element of the human vascular endothelial growth factor gene mediates transcriptional regulation by nitric oxide: control of hypoxia-inducible factor-1 activity by nitric oxide. Blood 2000; 95:189-97.

140. Kimura H, Weisz A, Ogura T, Hitomi Y, Kurashima Y, Hashimoto K, D’Acquisto F, Makuuchi M, Esumi H. Identification of hypoxia-inducible factor 1 ancillary sequence and its function in vascular endothelial growth factor gene induction by hypoxia and nitric oxide. J Biol Chem 2001; 276:2292-8.

141. Shweiki D, Itin A, Soffer D, Keshet E. Vascular endothelial growth factor induced by hypoxia may mediate hypoxia-initiated angiogenesis. Nature 1992; 359:843-5.

142. Shweiki D, Neeman M, Itin A, Keshet E. Induction of vascular endothelial growth factor expression by hypoxia and by glucose deficiency in multicell spheroids: implications for tumor angiogenesis. Proc Natl Acad Sci USA 1995; 92:768-72.

143. Pe'er J, Shweiki D, Itin A, Hemo I, Gnessin H, Keshet E. Hypoxia-induced expression of vascular endothelial growth factor by retinal cells is a common factor in neovascularizing ocular diseases. Lab Invest 1995; 72:638-45.

144. Moscatelli D, Presta M,Joseph-Silverstein J, Rifkin DB. Both normal and tumor cells produce basic fibroblast growth factor. J Cell Physiol 1986; 129:273-6.

145. Presta M, Moscatelli D, Joseph-Silverstein J, Rifkin DB. Purification from a human 
hepatoma cell line of a basic fibroblast growth factor-like molecule that stimulates capillary endothelial cell plasminogen activator production, DNA synthesis, and migration. Mol Cell Biol 1986; 6:4060-6.

146. Thomas KA. Fibroblast growth factors. FASEB J 1987; 1:434-40.

147. Mignatti $\mathrm{P}$, Tsuboi R, Robbins E, Rifkin DB. In vitro angiogenesis on the human amniotic membrane: requirement for basic fibroblast growth factor-induced proteinases. J Cell Biol 1989; 108:671-82.

148. Gospodarowicz D, Ferrara N, Schweigerer L, Neufeld G. Structural characterization and biological functions of fibroblast growth factor. Endocr Rev 1987; 8:95-114.

149. Terranova VP, DiFlorio R, Lyall RM, Hic S, Friesel R, Maciag T. Human endothelial cells are chemotactic to endothelial cell growth factor and heparin. J Cell Biol 1985; 101:2330-4.

150. Pepper MS, Belin D, Montesano R, Orci L, Vassalli JD. Transforming growth factorbeta 1 modulates basic fibroblast growth factor-induced proteolytic and angiogenic properties of endothelial cells in vitro. J Cell Biol 1990; 111:743-55.

151. Klein S, Roghani M, Rifkin DB. Fibroblast growth factors as angiogenesis factors: new insights into their mechanism of action. EXS 1997; 79:159-92.

152. Johnson DE, Williams LT. Structural and functional diversity in the FGF receptor multigene family. Adv Cancer Res 1993; 60:1-41.

153. Rusnati M, Presta M. Interaction of angiogenic basic fibroblast growth factor with endothelial cell heparan sulfate proteoglycans. Biological implications in neovascularization. Int J Clin Lab Res 1996; 26:15-23.

154. Heldin CH, Westermark B. Mechanism of action and in vivo role of platelet-derived growth factor. Physiol Rev 1999; 79:1283-316.

155. Battegay EJ, Rupp J, Iruela-Arispe L, Sage EH, Pech M. PDGF-BB modulates endothelial proliferation and angiogenesis in vitro via PDGF beta-receptors. J Cell Biol 1994; 125:917-28.

156. Bar RS, Boes M, Booth BA, Dake BL, Henley S, Hart MN. The effects of plateletderived growth factor in cultured microvessel endothelial cells. Endocrinology 1989; 124:1841-8.

157. Nicosia RF, Nicosia SV, Smith M. Vascular endothelial growth factor, platelet-derived growth factor, and insulin-like growth factor-1 promote rat aortic angiogenesis in vitro. Am J Pathol 1994; 145:1023-9.

158. D'Amore PA, Smith SR. Growth factor effects on cells of the vascular wall: a survey. Growth Factors 1993; 8:61-75.

159. Leveen P, Pekny M, Gebre-Medhin S, Swolin B, Larsson E, Betsholtz C. Mice deficient for PDGF B show renal, cardiovascular, and hematological abnormalities. Genes Dev 1994; 8:1875-87.

160. Lindahl P, Johansson BR, Leveen P, Betsholtz C. Pericyte loss and microaneurysm formation in PDGF-B-deficient mice. Science 1997; 277:242-5.

161. Hellstrom M, Kalen M, Lindahl P, Abramsson A, Betsholtz C. Role of PDGF-B and PDGFR-beta in recruitment of vascular smooth muscle cells and pericytes during embryonic blood vessel formation in the mouse. Development 1999; 126:3047-55. 
162. Soriano P. Abnormal kidney development and hematological disorders in PDGF beta-receptor mutant mice. Genes Dev 1994; 8:1888-96.

163. Piascik P. Use of Regranex gel for diabetic foot ulcers. J Am Pharm Assoc (Wash) 1998; 38:628-30.

164. Miller MS. Use of topical recombinant human platelet-derived growth factor-BB (becaplermin) in healing of chronic mixed arteriovenous lower extremity diabetic ulcers. J Foot Ankle Surg 1999; 38:227-31.

165. Derynck R, Jarrett JA, Chen EY, Eaton DH, Bell JR, Assoian RK, Roberts AB, Sporn $\mathrm{MB}$, Goeddel DV. Human transforming growth factor-beta complementary DNA sequence and expression in normal and transformed cells. Nature 1985; 316:701-5.

166. Massague J. The transforming growth factor-beta family. Annu Rev Cell Biol 1990; 6:597-641.

167. Antonelli-Orlidge A, Saunders KB, Smith SR, D'Amore PA. An activated form of transforming growth factor beta is produced by cocultures of endothelial cells and pericytes. Proc Natl Acad Sci USA 1989; 86:4544-8.

168. Yang EY, Moses HL. Transforming growth factor beta 1 -induced changes in cell migration, proliferation, and angiogenesis in the chicken chorioallantoic membrane. J Cell Biol 1990; 111:731-41.

169. Roberts AB, Sporn MB, Assoian RK, Smith JM, Roche NS, Wakefield LM, Heine UI, Liotta LA, Falanga V, Kehrl JH, et al. Transforming growth factor type beta: rapid induction of fibrosis and angiogenesis in vivo and stimulation of collagen formation in vitro. Proc Natl Acad Sci USA 1986; 83:4167-71.

170. Pierce GF, Tarpley JE, Yanagihara D, Mustoe TA, Fox GM, Thomason A. Plateletderived growth factor (BB homodimer), transforming growth factor-beta 1 , and basic fibroblast growth factor in dermal wound healing. Neovessel and matrix formation and cessation of repair. Am J Pathol 1992; 140:1375-88.

171. Phillips GD, Whitehead RA, Knighton DR. Inhibition by methylprednisolone acetate suggests an indirect mechanism for TGF-B induced angiogenesis. Growth Factors 1992; 6:77-84.

172. Pepper MS. Transforming growth factor-beta: vasculogenesis, angiogenesis, and vessel wall integrity. Cytokine Growth Factor Rev 1997; 8:21-43.

173. Davis S, Yancopoulos GD. The angiopoietins: yin and yang in angiogenesis. Curr Top Microbiol Immunol 1999; 237:173-85.

174. Davis S, Aldrich TH, Jones PF, Acheson A, Compton DL, Jain V, Ryan TE, Bruno J, Radziejewski C, Maisonpierre PC, Yancopoulos GD. Isolation of angiopoietin-1, a ligand for the TIE2 receptor, by secretion-trap expression cloning. Cell 1996; 87: 1161-9.

175. Suri C, Jones PF, Patan S, Bartunkova S, Maisonpierre PC, Davis S, Sato TN, Yancopoulos GD. Requisite role of angiopoietin-1, a ligand for the TIE2 receptor, during embryonic angiogenesis. Cell 1996; 87:1171-80.

176. Thurston G, Suri C, Smith K, McClain J, Sato TN, Yancopoulos GD, McDonald DM. Leakage-resistant blood vessels in mice transgenically overexpressing angiopoietin-1. Science 1999; 286:2511-4. 
177. Maisonpierre PC, Suri C, Jones PF, Bartunkova S, Wiegand SJ, Radziejewski C, Compton D, McClain J, Aldrich TH, Papadopoulos N, Daly TJ, Davis S, Sato TN, Yancopoulos GD. Angiopoietin-2, a natural antagonist for Tie2 that disrupts in vivo angiogenesis. Science 1997; 277:55-60.

178. Asahara T, Chen D, Takahashi T, Fujikawa K, Kearney M, Magner M, Yancopoulos GD, Isner JM. Tie2 receptor ligands, angiopoietin-1 and angiopoietin-2, modulate VEGF-induced postnatal neovascularization. Circ Res 1998; 83:233-40.

179. Korpelainen EI, Alitalo K. Signaling angiogenesis and lymphangiogenesis. Curr Opin Cell Biol 1998; 10:159-64.

180. Adams JC, Watt FM. Regulation of development and differentiation by the extracellular matrix. Development 1993; 117:1183-98.

181. Juliano RL, Haskill S. Signal transduction from the extracellular matrix. J Cell Biol 1993; 120:577-85.

182. Haralabopoulos GC, Grant DS, Kleinman HK, Maragoudakis ME. Thrombin promotes endothelial cell alignment in Matrigel in vitro and angiogenesis in vivo. Am J Physiol 1997; 273:C239-45.

183. Dvorak HF, Harvey VS, Estrella P, Brown LF, McDonagh J, Dvorak AM. Fibrin containing gels induce angiogenesis. Implications for tumor stroma generation and wound healing. Lab Invest 1987; 57:673-86.

184. Nicosia RF, Bonanno E, Smith M. Fibronectin promotes the elongation of microvessels during angiogenesis in vitro. J Cell Physiol 1993; 154:654-61.

185. Kanzawa S, Endo H, Shioya N. Improved in vitro angiogenesis model by collagen density reduction and the use of type III collagen. Ann Plast Surg 1993; 30:244-51.

186. Shakado S, Sakisaka S, Noguchi K, Yoshitake M, Harada M, Mimura Y, Sata M, Tanikawa K. Effects of extracellular matrices on tube formation of cultured rat hepatic sinusoidal endothelial cells. Hepatology 1995; 22:969-73.

187. Takei A, Tashiro Y, Nakashima Y, Sueishi K. Effects of fibrin on the angiogenesis in vitro of bovine endothelial cells in collagen gel. In Vitro Cell Dev Biol Anim 1995; 31:467-72.

188. Vernon RB, Lara SL, Drake CJ,Iruela-Arispe ML, Angello JC, Little CD, Wight TN, Sage EH. Organized type I collagen influences endothelial patterns during "spontaneous angiogenesis in vitro": planar cultures as models of vascular development. In Vitro Cell Dev Biol Anim 1995; 31:120-31.

189. Hynes RO. Integrins: versatility, modulation, and signaling in cell adhesion. Cell 1992; 69:11-25.

190. Sastry SK, Horwitz AF. Integrin cytoplasmic domains: mediators of cytoskeletal linkages and extra- and intracellular initiated transmembrane signaling. Curr Opin Cell Biol 1993; 5:819-31.

191. Schwartz M, Schaller M, Ginsberg M. Integrins: emerging paradigms of signal transduction. Ann Rev Cell Dev Biol 1995; 11:549-99.

192. Schwartz MA, Shattil SJ. Signaling networks linking integrins and rho family GTPases. Trends Biochem Sci 2000; 25:388-91. 
193. Keely P, Parise L, Juliano R. Integrins and GTPases in tumour cell growth, motility and invasion. Trends Cell Biol 1998; 8:101-6.

194. Cary LA, Han DC, Guan JL. Integrin-mediated signal transduction pathways. Histol Histopathol 1999; 14:1001-9.

195. Friedlander M, Brooks PC, Shaffer RW, Kincaid CM, Varner JA, Cheresh DA. Definition of two angiogenic pathways by distinct alpha v integrins. Science 1995; 270: 1500-2.

196. Eliceiri BP, Cheresh DA. The role of alphav integrins during angiogenesis: insights into potential mechanisms of action and clinical development. J Clin Invest 1999; 103:1227-30.

197. Clark RA, Tonnesen MG, Gailit J, Cheresh DA. Transient functional expression of alphaVbeta 3 on vascular cells during wound repair. Am J Pathol 1996; 148:1407-21.

198. Brooks PC, Stromblad S, Sanders LC, von Schalscha TL, Aimes RT, Stetler-Stevenson WG, Quigley JP, Cheresh DA. Localization of matrix metalloproteinase MMP-2 to the surface of invasive cells by interaction with integrin alpha v beta 3 . Cell 1996; 85: 683-93.

199. Stromblad S, Becker JC, Yebra M, Brooks PC, Cheresh DA. Suppression of p53 activity and p21WAF1/CIP1 expression by vascular cell integrin alphaVbeta3 during angiogenesis. J Clin Invest 1996; 98:426-33.

200. Seandel M, Noack-Kunnmann K, Zhu D, Aimes RT, Quigley JP. Growth factor-induced angiogenesis in vivo requires specific cleavage of fibrillar type I collagen. Blood 2001; 97:2323-32.

201. Liekens S, De Clercq E, Neyts J. Angiogenesis: regulators and clinical applications. Biochem Pharmacol 2001; 61:253-70.

202. Mignatti P, Rifkin DB. Plasminogen activators and angiogenesis. Curr Top Microbiol Immunol 1996; 213(Pt 1):33-50.

203. Mignatti P, Rifkin DB. Plasminogen activators and matrix metalloproteinases in angiogenesis. Enzyme Protein 1996; 49:117-37.

204. Vu TH, Werb Z. Matrix metalloproteinases: effectors of development and normal physiology. Genes Dev 2000; 14:2123-33.

205. Schnaper HW, Grant DS, Stetler-Stevenson WG, Fridman R, D’Orazi G, Murphy AN, Bird RE, Hoythya M, Fuerst TR, French DL, et al. Type IV collagenase(s) and TIMPs modulate endothelial cell morphogenesis in vitro. J Cell Physiol 1993; 156: 235-46.

206. Stetler-Stevenson WG. Matrix metalloproteinases in angiogenesis: a moving target for therapeutic intervention. J Clin Invest 1999; 103:1237-41.

207. Pepper MS. Role of the matrix metalloproteinase and plasminogen activator-plasmin systems in angiogenesis. Arterioscler Thromb Vasc Biol 2001; 21:1104-17.

208. Arihiro S, Ohtani H, Hiwatashi N, Torii A, Sorsa T, Nagura H. Vascular smooth muscle cells and pericytes express MMP-1,MMP-9, TIMP-1 and type I procollagen in inflammatory bowel disease. Histopathology 2001; 39:50-9.

209. Nielsen BS, Sehested M, Kjeldsen L, Borregaard N, Rygaard J, Dano K. Expression 
of matrix metalloprotease-9 in vascular pericytes in human breast cancer. Lab Invest 1997; 77:345-55.

210. Taraboletti G, D’Ascenzo S, Borsotti P, Giavazzi R, Pavan A, Dolo V. Shedding of the matrix metalloproteinases MMP-2, MMP-9, and MT1-MMP as membrane vesicle-associated components by endothelial cells. Am J Pathol 2002; 160: 673-80.

211. Wannier-Morino P, Rager G, Sonderegger P, Grabs D. Expression of neuroserpin in the visual cortex of the mouse during the developmental critical period. Eur J Neurosci 2003; 17:1853-60.

212. Brooks PC, Silletti S, von Schalscha TL, Friedlander M, Cheresh DA. Disruption of angiogenesis by $\mathrm{PEX}$, a noncatalytic metalloproteinase fragment with integrin binding activity. Cell 1998; 92:391-400.

213. O'Reilly MS, Holmgren L, Shing Y, Chen C, Rosenthal RA, Moses M, Lane WS, Cao Y, Sage EH, Folkman J. Angiostatin: a novel angiogenesis inhibitor that mediates the suppression of metastases by a Lewis lung carcinoma. Cell 1994; 79:315-28.

214. Ji WR, Barrientos LG, Llinas M, Gray H, Villarreal X, DeFord ME, Castellino FJ, Kramer RA, Trail PA. Selective inhibition by kringle 5 of human plasminogen on endothelial cell migration, an important process in angiogenesis. Biochem Biophys Res Commun 1998; 247:414-9.

215. Cao Y, Chen A, An SS, Ji RW, Davidson D, Llinas M. Kringle 5 of plasminogen is a novel inhibitor of endothelial cell growth. J Biol Chem 1997; 272:22924-8.

216. Petzelbauer P, Halama T, Groger M. Endothelial adherens junctions.J Invest Dermatol Symp Proc 2000; 5:10-3.

217. Newman PJ. The biology of PECAM-1. J Clin Invest 1997; 100:S25-9.

218. Halama T, Staffler G, Hoch S, Stockinger H, Wolff K, Petzelbauer P. Vascularendothelial cadherin (CD144)- but not PECAM-1 (CD31)-based cell-to-cell contacts convey the maintenance of a quiescent endothelial monolayer. Int Arch Allergy Immunol 1999; 120:237-44.

219. Ilan N,Mahooti S, Rimm DL, MadriJA. PECAM-1 (CD31) functions as a reservoir for and a modulator of tyrosine-phosphorylated beta-catenin.J Cell Sci 1999; $112 \mathrm{Pt}$ 18:3005-14.

220. Gale NW, Yancopoulos GD. Growth factors acting via endothelial cell-specific receptor tyrosine kinases: VEGFs, angiopoietins, and ephrins in vascular development. Genes Dev 1999; 13:1055-66.

221. Chien S, Li S, Shiu YT,Li YS.Molecular basis of mechanical modulation of endothelial cell migration. Frontiers Biosci 2005; 10:1985-2000.

222. Bell SE, Mavila A, Salazar R, Bayless KJ, Kanagala S, Maxwell SA, Davis GE. Differential gene expression during capillary morphogenesis in $3 \mathrm{D}$ collagen matrices: regulated expression of genes involved in basement membrane matrix assembly, cell cycle progression, cellular differentiation and G-protein signaling. J Cell Sci 2001; 114:2755-73.

223. Zogakis TG, Costouros NG, Kruger EA, Forbes S, He M, Qian M, Feldman AL, Figg WD, Alexander HR, Liu ET, Kohn EC, Libutti SK. Microarray gene expression 
profiling of angiogenesis inhibitors using the rat aortic ring assay. Biotechniques 2002; 33:664-6, 68, 70.

224. Davies PF. Flow-mediated endothelial mechanotransduction. Physiol Rev 1995; 75: 519-60.

225. Fung YC. A first course in continuum mechanics: for physical and biological scientists and engineers. 3 ed. Englewood Cliffs NJ: Prentice Hall, 1994.

226. Fung YC. Biomechanics: mechanical properties of living tissues. 2 ed. New York: Springer-Verlag, 1993.

227. Bershadsky AD, Balaban NQ, Geiger B. Adhesion-dependent cell mechanosensitivity. Annu Rev Cell Dev Biol 2003; 19:677-95.

228. Chicurel ME, Chen CS, Ingber DE. Cellular control lies in the balance of forces. Curr Opin Cell Biol 1998; 10:232-9.

229. Zhu C, Bao G, Wang N. Cell mechanics: mechanical responses, cell adhesion, and molecular deformation. Annu Rev Biomed Eng 2000; 2:189-226.

230. Janmey PA. The cytoskeleton and cell signaling: component localization and mechanical coupling. Physiol Rev 1998; 78:763-81.

231. Hall A. Rho GTPases and the actin cytoskeleton. Science 1998; 279:509-14.

232. Mitchison TJ. Evolution of a dynamic cytoskeleton. Phil Trans R Soc Lond B Biol Sci 1995; 349:299-304.

233. Galbraith CG, Sheetz MP. Forces on adhesive contacts affect cell function. Curr Opin Cell Biol 1998; 10:566-71.

234. Katsumi A, Orr AW, Tzima E, Schwartz MA. Integrins in mechanotransduction. J Biol Chem 2004; 279:12001-4.

235. Kano Y, Katoh K, Fujiwara K. Lateral zone of cell-cell adhesion as the major fluid shear stress-related signal transduction site. Circ Res 2000; 86:425-33.

236. Mathur AB, Truskey GA, Reichert WM. Atomic force and total internal reflection fluorescence microscopy for the study of force transmission in endothelial cells. Biophys J 2000; 78:1725-35.

237. Mathur AB, Truskey GA, Reichert WM. Total internal reflection microscopy and atomic force microscopy (TIRFM-AFM) to study stress transduction mechanisms in endothelial cells. Crit Rev Biomed Eng 2000; 28:197-202.

238. Zhao S, Suciu A,Ziegler T, Moore JE,Jr., Burki E, Meister JJ, Brunner HR. Synergistic effects of fluid shear stress and cyclic circumferential stretch on vascular endothelial cell morphology and cytoskeleton. Arterioscler Thromb Vasc Biol 1995; 15:1781-6.

239. Wang N, Butler JP, Ingber DE. Mechanotransduction across the cell surface and through the cytoskeleton. Science 1993; 260:1124-7.

240. Maniotis AJ, Chen CS, Ingber DE. Demonstration of mechanical connections between integrins, cytoskeletal filaments, and nucleoplasm that stabilize nuclear structure. Proc Natl Acad Sci USA 1997; 94:849-54.

241. Geiger B, Bershadsky A. Assembly and mechanosensory function of focal contacts. Curr Opin Cell Biol 2001; 13:584-92.

242. Geiger B, Bershadsky A. Exploring the neighborhood: adhesion-coupled cell mechanosensors. Cell 2002; 110:139-42. 
243. Burridge K, Chrzanowska-Wodnicka M. Focal adhesions, contractility, and signaling. Annu Rev Cell Dev Biol 1996; 12:463-518.

244. Ingber DE. Tensegrity I. Cell structure and hierarchical systems biology. J Cell Sci 2003; 116:1157-73.

245. Ingber DE. Tensegrity II. How structural networks influence cellular information processing networks. J Cell Sci 2003; 116:1397-408.

246. Narumiya S, Ishizaki T, Watanabe N. Rho effectors and reorganization of actin cytoskeleton. FEBS Lett 1997; 410:68-72.

247. Amano M, Ito M, Kimura K, Fukata Y, Chihara K, Nakano T, Matsuura Y, Kaibuchi K. Phosphorylation and activation of myosin by Rho-associated kinase (Rho-kinase). J Biol Chem 1996; 271:20246-9.

248. Amano M, Chihara K, Kimura K, Fukata Y, Nakamura N, Matsuura Y, Kaibuchi K. Formation of actin stress fibers and focal adhesions enhanced by Rho-kinase. Science 1997; 275:1308-11.

249. Chrzanowska-Wodnicka M, Burridge K. Rho-stimulated contractility drives the formation of stress fibers and focal adhesions. J Cell Biol 1996; 133:1403-15.

250. Zhong C, Chrzanowska-Wodnicka M, Brown J, Shaub A, Belkin AM, Burridge K. Rho-mediated contractility exposes a cryptic site in fibronectin and induces fibronectin matrix assembly. J Cell Biol 1998; 141:539-51.

251. Beningo KA, Wang YL. Flexible substrata for the detection of cellular traction forces. Trends Cell Biol 2002; 12:79-84.

252. Elson EL, Felder SF, Jay PY, Kolodney MS, Pasternak C. Forces in cell locomotion. Biochem Soc Symp 1999; 65:299-314.

253. Lauffenburger DA, Horwitz AF. Cell migration: a physically integrated molecular process. Cell 1996; 84:359-69.

254. Sheetz MP, Felsenfeld D, Galbraith CG, Choquet D. Cell migration as a five-step cycle. Biochem Soc Symp 1997; 65:233-43.

255. Beningo KA, Lo CM, Wang YL. Flexible polyacrylamide substrata for the analysis of mechanical interactions at cell-substratum adhesions. Methods Cell Biol 2002; 69: 325-39.

256. Marganski WA, Dembo M,Wang YL. Measurements of cell-generated deformations on flexible substrata using correlation-based optical flow. Methods Enzymol 2003; 361:197-211.

257. Harris AK, Wild P, Stopak D. Silicone rubber substrata: a new wrinkle in the study of cell locomotion. Science 1980; 208:177-9.

258. Balaban NQ, Schwarz US, Riveline D, Goichberg P, Tzur G, Sabanay I, Mahalu D, Safran S, Bershadsky A, Addadi L, Geiger B. Force and focal adhesion assembly: a close relationship studied using elastic micropatterned substrates. Nat Cell Biol 2001; 3:466-72.

259. Wang N, Naruse K, Stamenovic D, Fredberg JJ, Mijailovich SM, Tolic-Norrelykke IM, Polte T, Mannix R, Ingber DE. Mechanical behavior in living cells consistent with the tensegrity model. Proc Natl Acad Sci USA 2001; 98:7765-70.

260. Stamenovic D, Liang Z, Chen J, Wang N. Effect of the cytoskeletal prestress on the 
mechanical impedance of cultured airway smooth muscle cells. J Appl Physiol 2002; 92:1443-50.

261. Brown RA, Talas G, Porter RA, McGrouther DA, Eastwood M. Balanced mechanical forces and microtubule contribution to fibroblast contraction.J Cell Physiol 1996; 169: 439-47.

262. Dennerll TJ, Joshi HC, Steel VL, Buxbaum RE, Heidemann SR. Tension and compression in the cytoskeleton of PC-12 neurites. II: Quantitative measurements. J Cell Biol 1988; 107:665-74.

263. Nelson CM, Pirone DM, Tan JL, Chen CS. Vascular endothelial-cadherin regulates cytoskeletal tension, cell spreading, and focal adhesions by stimulating RhoA. Mol Biol Cell 2004; 15:2943-53.

264. Ryan PL, Foty RA, Kohn J, Steinberg MS. Tissue spreading on implantable substrates is a competitive outcome of cell-cell vs. cell-substratum adhesivity. Proc Natl Acad Sci USA 2001; 98:4323-7.

265. Silver FH, Siperko LM. Mechanosensing and mechanochemical transduction: how is mechanical energy sensed and converted into chemical energy in an extracellular matrix? Crit Rev Biomed Eng 2003; 31:255-331.

266. Reinhart-King CA, Dembo M, Hammer DA. Endothelial cell traction forces on RGD-derivatized polyacrylamide substrata. Langmuir 2003; 19:1573-79.

267. Wang HB, Dembo M, Wang YL. Substrate flexibility regulates growth and apoptosis of normal but not transformed cells. Am J Physiol Cell Physiol 2000; 279:C1345-50.

268. Kolodney MS, Wysolmerski RB. Isometric contraction by fibroblasts and endothelial cells in tissue culture: a quantitative study. J Cell Biol 1992; 117:73-82.

269. Pelham RJ Jr, Wang Y. Cell locomotion and focal adhesions are regulated by substrate flexibility. Proc Natl Acad Sci USA 1997; 94:13661-5.

270. Pelham RJ Jr, Wang Y. High resolution detection of mechanical forces exerted by locomoting fibroblasts on the substrate. Mol Biol Cell 1999; 10:935-45.

271. Munevar S, Wang Y, Dembo M. Traction force microscopy of migrating normal and H-ras transformed 3T3 fibroblasts. Biophys J 2001; 80:1744-57.

272. Munevar S, Wang Y1 YL, Dembo M. Distinct roles of frontal and rear cell-substrate adhesions in fibroblast migration. Mol Biol Cell 2001; 12:3947-54.

273. Beningo KA, Dembo M, Kaverina I, Small JV, Wang YL. Nascent focal adhesions are responsible for the generation of strong propulsive forces in migrating fibroblasts. J Cell Biol 2001; 153:881-8.

274. Uchida S, Watanabe G, Shimada Y, Maeda M, Kawabe A, Mori A, Arii S, Uehata M, Kishimoto T, Oikawa T, Imamura M. The suppression of small GTPase rho signal transduction pathway inhibits angiogenesis in vitro and in vivo. Biochem Biophys Res Commun 2000; 269:633-40.

275. Harris AK, Stopak D, Wild P. Fibroblast traction as a mechanism for collagen morphogenesis. Nature 1981; 290:249-51.

276. Stopak D, Harris AK. Connective tissue morphogenesis by fibroblast traction. I. Tissue culture observations. Dev Biol 1982; 90:383-98.

277. Vernon RB, Angello JC, Iruela-Arispe ML, Lane TF, Sage EH. Reorganization of 
basement membrane matrices by cellular traction promotes the formation of cellular networks in vitro. Lab Invest 1992; 66:536-47.

278. Vernon RB, Sage EH. Between molecules and morphology. Extracellular matrix and creation of vascular form. Am J Pathol 1995; 147:873-83.

279. Thoumine O, Nerem RM, Girard PR. Changes in organization and composition of the extracellular matrix underlying cultured endothelial cells exposed to laminar steady shear stress. Lab Invest 1995; 73:565-76.

280. Fournier N, Doillon CJ. In vitro angiogenesis in fibrin matrices containing fibronectin or hyaluronic acid. Cell Biol Int Rep 1992; 16:1251-63.

281. Folkman J. Tumor angiogenesis. Adv Cancer Res 1985; 43:175-203.

282. Dike LE, Chen CS, Mrksich M,Tien J, Whitesides GM, Ingber DE. Geometric control of switching between growth, apoptosis, and differentiation during angiogenesis using micropatterned substrates. In Vitro Cell Dev Biol Anim 1999; 35:441-8.

283. Harris AK, Stopak D, Warner P. Generation of spatially periodic patterns by a mechanical instability: a mechanical alternative to the Turing model. J Embryol Exp Morphol 1984; 80:1-20.

284. Grant DS, Tashiro K, Segui-Real B, Yamada Y, Martin GR, Kleinman HK. Two different laminin domains mediate the differentiation of human endothelial cells into capillary-like structures in vitro. Cell 1989; 58:933-43.

285. Davis GE, Camarillo CW. Regulation of endothelial cell morphogenesis by integrins, mechanical forces, and matrix guidance pathways. Exp Cell Res 1995; 216:113-23.

286. Vailhe B, Ronot X, Tracqui P, Usson Y, Tranqui L. In vitro angiogenesis is modulated by the mechanical properties of fibrin gels and is related to alpha(v)beta3 integrin localization. In Vitro Cell Dev Biol Anim 1997; 33:763-73.

287. Sieminski AL, Hebbel RP, Gooch KJ. The relative magnitudes of endothelial force generation and matrix stiffness modulate capillary morphogenesis in vitro. Exp Cell Res 2004; 297:574-84.

288. Namy P, Ohayon J, Tracqui P. Critical conditions for pattern formation and in vitro tubulogenesis driven by cellular traction fields. J Theor Biol 2004; 227:103-20.

289. Miyamoto S, Teramoto H, Coso OA, Gutkind JS, Burbelo PD, Akiyama SK, Yamada KM. Integrin function: molecular hierarchies of cytoskeletal and signaling molecules. J Cell Biol 1995; 131:791-805.

290. Miyamoto S, Akiyama SK, Yamada KM. Synergistic roles for receptor occupancy and aggregation in integrin transmembrane function. Science 1995; 267:883-5.

291. Ingber DE. Fibronectin controls capillary endothelial cell growth by modulating cell shape. Proc Natl Acad Sci USA 1990; 87:3579-83.

292. Huang S, Ingber DE. The structural and mechanical complexity of cell-growth control. Nat Cell Biol 1999; 1:E131-8.

293. Chen CS, Mrksich M, Huang S, Whitesides GM, Ingber DE. Geometric control of cell life and death. Science 1997; 276:1425-8.

294. Halliday NL, Tomasek JJ. Mechanical properties of the extracellular matrix influence fibronectin fibril assembly in vitro. Exp Cell Res 1995; 217:109-17.

295. Geiger B, Bershadsky A, Pankov R, Yamada KM. Transmembrane crosstalk between 
the extracellular matrix-cytoskeleton crosstalk. Nat Rev Mol Cell Biol 2001; 2: 793-805.

296. Wang N, Ostuni E, Whitesides GM, Ingber DE. Micropatterning tractional forces in living cells. Cell Motil Cytoskeleton 2002; 52:97-106.

297. Polte TR, Eichler GS, Wang N, Ingber DE. Extracellular matrix controls myosin light chain phosphorylation and cell contractility through modulation of cell shape and cytoskeletal prestress. Am J Physiol Cell Physiol 2004; 286:C518-28.

298. Kuzuya M, Satake S, Miura H, Hayashi T, Iguchi A. Inhibition of endothelial cell differentiation on a glycosylated reconstituted basement membrane complex. Exp Cell Res 1996; 226:336-45.

299. Deroanne CF, Lapiere CM, Nusgens BV. In vitro tubulogenesis of endothelial cells by relaxation of the coupling extracellular matrix-cytoskeleton. Cardiovasc Res 2001; 49:647-58.

300. Kuzuya M, Satake S, Ai S, Asai T, Kanda S, Ramos MA, Miura H, Ueda M, Iguchi A. Inhibition of angiogenesis on glycated collagen lattices. Diabetologia 1998; 41: 491-9.

301. Nehls V, Herrmann R. The configuration of fibrin clots determines capillary morphogenesis and endothelial cell migration. Microvasc Res 1996; 51:347-64.

302. Banerjee SD, Cohn RH, Bernfield MR. Basal lamina of embryonic salivary epithelia. Production by the epithelium and role in maintaining lobular morphology.J Cell Biol 1977; 73:445-63.

303. Ferrara N. Vascular endothelial growth factor: molecular and biological aspects. Curr Top Microbiol Immunol 1999; 237:1-30.

304. Hattori S, Fujisaki H, Kiriyama T, Yokoyama T, Irie S. Real-time zymography and reverse zymography: a method for detecting activities of matrix metalloproteinases and their inhibitors using FITC- labeled collagen and casein as substrates. Anal Biochem 2002; 301:27-34.

305. Fernandez HA, Kallenbach K, Seghezzi G, Grossi E, Colvin S, Schneider R, Mignatti $\mathrm{P}$, Galloway A. Inhibition of endothelial cell migration by gene transfer of tissue inhibitor of metalloproteinases-1. J Surg Res 1999; 82:156-62.

306. Partridge CR, Hawker JR Jr, Forough R. Overexpression of a secretory form of FGF-1 promotes MMP-1-mediated endothelial cell migration. J Cell Biochem 2000; 78: 487-99.

307. Haas TL, Davis SJ, Madri JA. Three-dimensional type I collagen lattices induce coordinate expression of matrix metalloproteinases MT1-MMP and MMP-2 in microvascular endothelial cells. J Biol Chem 1998; 273:3604-10.

308. Haas TL, Madri JA. Extracellular matrix-driven matrix metalloproteinase production in endothelial cells: implications for angiogenesis. Trends Cardiovasc Med 1999; 9: $70-7$.

309. Zhu WH, Guo X, Villaschi S, Francesco Nicosia R. Regulation of vascular growth and regression by matrix metalloproteinases in the rat aorta model of angiogenesis. Lab Invest 2000; 80:545-55.

310. Brummer O, Bohmer G, Hollwitz B, Flemming P, Petry K-U, Kuhnle H. MMP-1 
and MMP-2 in the cervix uteri in different steps of malignant transformation-an immunohistochemical study. Gynecologic Oncology 2002; 84:222-27.

311. Schutz A, Schneidenbach D, Aust G, Tannapfel A, Steinert M, Wittekind C. Differential expression and activity status of MMP-1, MMP-2 and MMP-9 in tumor and stromal cells of squamous cell carcinomas of the lung. Tumour Biol 2002; 23:179-84.

312. Krishnan L, Song H, Hoying JB, Das R, Weiss JA. Angiogenesis alters the material properties of the extracellular matrix. $4^{\text {th }}$ Annual Orthopaedic Research Society Meeting 2003; 28:278.

313. Krishnan L, Song H, Hoying JB, Weiss JA. Effects of angiogenesis on the material properties of the extracellular matrix: correlation with gene expression. Proc ASME Summer Bioengineering Conference 2003:949-50.

314. Krishnan L, Weiss JA, Wessman MD, Hoying JB. Design and application of a test system for viscoelastic characterization of collagen gels. Tissue Eng 2004; 10:241-52.

315. Vandesompele J, De Preter K, Pattyn F, Poppe B, Van Roy N, De Paepe A, Speleman F. Accurate normalization of real-time quantitative RT-PCR data by geometric averaging of multiple internal control genes. Genome Biol 2002; 3:0034.1-34.11.

316. Berk BC, Abe JI, Min W, Surapisitchat J, Yan C. Endothelial atheroprotective and anti-inflammatory mechanisms. Ann NY Acad Sci 2001; 947:93-109; discussion 09-11.

317. Chien S, Li S, Shyy YJ. Effects of mechanical forces on signal transduction and gene expression in endothelial cells. Hypertension 1998:162-9.

318. Davies PF, Barbee KA, Lal R, Robotewskyj A, Griem ML. Hemodynamics and atherogenesis. Endothelial surface dynamics in flow signal transduction. Ann NY Acad Sci 1995; 748:86-102; discussion 102-3.

319. Gooch KJ,Tennant CJ.Mechanical forces: their effects on cells and tissues. New York: Springer, 1997.

320. McIntire LV.1992 ALZA Distinguished lecture: bioengineering and vascular biology. Ann Biomed Eng 1994; 22:2-13.

321. Papadaki M, Eskin SG. Effects of fluid shear stress on gene regulation of vascular cells. Biotechnol Prog 1997; 13:209-21.

322. Patrick CW Jr, McIntire LV. Shear stress and cyclic strain modulation of gene expression in vascular endothelial cells. Blood Purif 1995; 13:112-24.

323. Shyy JY.Mechanotransduction in endothelial responses to shear stress: review of work in Dr. Chien's laboratory. Biorheology 2001; 38:109-17.

324. Shyy JY, Chien S. Role of integrins in endothelial mechanosensing of shear stress. Circ Res 2002; 91:769-75.

325. Skalak TC, Price RJ. The role of mechanical stresses in microvascular remodeling. Microcirculation 1996; 3:143-65.

326. Liu SQ. Biomechanical basis of vascular tissue engineering. Crit Rev Biomed Eng 1999; 27:75-148.

327. Fung YC. Biomechanics: Circulation. 2 ed. New York: Springer-Verlag, 1997.

328. Clark ER. Studies on the growth of blood vessels in the tail of the frog larvae. Am J Anat 1918; 23:37-88. 
329. Cherry GW, Austad E, Pasyk K, McClatchey K, Rohrich RJ. Increased survival and vascularity of random-pattern skin flaps elevated in controlled, expanded skin. Plast Reconstr Surg 1983; 72:680-7.

330. Ziada A, Hudlicka O, Tyler KR. The effect of long-term administration of alpha 1blocker prazosin on capillary density in cardiac and skeletal muscle. Pflugers Arch 1989; 415:355-60.

331. Zhou A, Egginton S, Hudlicka O, Brown MD. Internal division of capillaries in rat skeletal muscle in response to chronic vasodilator treatment with alpha1-antagonist prazosin. Cell Tissue Res 1998; 293:293-303.

332. Van Gieson EJ, Skalak TC. Chronic vasodilation induces matrix metalloproteinase 9 (MMP-9) expression during microvascular remodeling in rat skeletal muscle. Microcirculation 2001; 8:25-31.

333. Tornling G, Adolfsson J, Unge G, Ljungqvist A. Capillary neoformation in skeletal muscle of dipyridamole-treated rats. Arzneimittelforschung 1980; 30:791-2.

334. Tornling G, Unge G, Adolfsson J, Ljungqvist A, Carlsson S. Proliferative activity of capillary wall cells in skeletal muscle of rats during long-term treatment with dipyridamole. Arzneimittelforschung 1980; 30:622-3.

335. Egginton S, Zhou AL, Brown MD, Hudlicka O. Unorthodox angiogenesis in skeletal muscle. Cardiovasc Res 2001; 49:634-46.

336. Ichioka S, Shibata M, Kosaki K, Sato Y, Harii K, Kamiya A. Effects of shear stress on wound-healing angiogenesis in the rabbit ear chamber. J Surg Res 1997; 72:29-35.

337. Rivilis I, Milkiewicz M, Boyd P, Goldstein J, Brown MD, Egginton S, Hansen FM, Hudlicka O, Haas TL. Differential involvement of MMP-2 and VEGF during muscle stretch- versus shear stress-induced angiogenesis. Am J Physiol Heart Circ Physiol 2002; 283:H1430-8.

338. Zhou AL, Egginton S, Brown MD, Hudlicka O. Capillary growth in overloaded, hypertrophic adult rat skeletal muscle: an ultrastructural study. Anat Rec 1998; 252: 49-63.

339. Egginton S, Hudlicka O, Brown MD, Walter H, Weiss JB, Bate A. Capillary growth in relation to blood flow and performance in overloaded rat skeletal muscle. J Appl Physiol 1998; 85:2025-32.

340. Haas TL, Milkiewicz M, Davis SJ, Zhou AL, Egginton S, Brown MD, Madri JA, Hudlicka O. Matrix metalloproteinase activity is required for activity-induced angiogenesis in rat skeletal muscle. Am J Physiol Heart Circ Physiol 2000; 279: H1540-7.

341. Myrhage R, Hudlicka O. Capillary growth in chronically stimulated adult skeletal muscle as studied by intravital microscopy and histological methods in rabbits and rats. Microvasc Res 1978; 16:73-90.

342. Armstrong PJ, Johanning JM, Calton WC Jr, Delatore JR, Franklin DP, Han DC, Carey DJ, Elmore JR. Differential gene expression in human abdominal aorta: aneurysmal versus occlusive disease. J Vasc Surg 2002; 35:346-55.

343. Yamaguchi S, Yamaguchi M, Yatsuyanagi E, Yun SS, Nakajima N, Madri JA, Sumpio BE. Cyclic strain stimulates early growth response gene product 1-mediated expres- 
sion of membrane type 1 matrix metalloproteinase in endothelium. Lab Invest 2002; 82:949-56.

344. Papadaki M, McIntire LV. Quantitative measurement of shear stress effects on endothelial cells. In: Morgan JR, Yarmuch ML, editors. Tissue Engineering Methods and Protocols. Totowa, NJ: Humana Press, 1998.

345. Joung IS, Shiu YT, Iwamoto MN, Li MW, Quam CT. Combined effects of fluid shear stress and matrix proteins on the remodeling of endothelial cells. Proceedings of the 2004 Annual Meeting of the Biomedical Engineering Society; 2004 Oct 13-16; Philadelphia, PA. Biomedical Engineering Society; 2004.

346. Davies PF, Robotewskyj A, Griem ML. Quantitative studies of endothelial cell adhesion. Directional remodeling of focal adhesion sites in response to flow forces. J Clin Invest 1994; 93:2031-8.

347. Eskin SG, Ives CL, McIntire LV, Navarro LT. Response of cultured endothelial cells to steady flow. Microvasc Res 1984; 28:87-94.

348. Girard PR, Nerem RM. Endothelial cell signaling and cytoskeletal changes in response to shear stress. Front Med Biol Eng 1993; 5:31-6.

349. Girard PR, Nerem RM. Shear stress modulates endothelial cell morphology and Factin organization through the regulation of focal adhesion-associated proteins.J Cell Physiol 1995; 163:179-93.

350. Levesque MJ, Nerem RM. The elongation and orientation of cultured endothelial cells in response to shear stress. J Biomech Eng 1985; 107:341-7.

351. Thoumine O, Ziegler T, Girard PR, Nerem RM. Elongation of confluent endothelial cells in culture: the importance of fields of force in the associated alterations of their cytoskeletal structure. Exp Cell Res 1995; 219:427-41.

352. Ueda A, Koga M, Ikeda M, Kudo S, Tanishita K. Effect of shear stress on microvessel network formation of endothelial cells with in vitro three-dimensional model. Am J Physiol Heart Circ Physiol 2004; 287:H994-1002.

353. Zheng W, Seftor EA, Meininger CJ, Hendrix MJ, Tomanek RJ. Mechanisms of coronary angiogenesis in response to stretch: role of VEGF and TGF-beta. Am J Physiol Heart Circ Physiol 2001; 280:H909-17.

354. Helmke BP, Thakker DB, Goldman RD, Davies PF. Spatiotemporal analysis of flowinduced intermediate filament displacement in living endothelial cells. Biophys J 2001; 80:184-94.

355. Hamill OP, Martinac B. Molecular basis of mechanotransduction in living cells. Physiol Rev 2001; 81:685-740.

356. Apodaca G. Modulation of membrane traffic by mechanical stimuli. Am J Physiol Renal Physiol 2002; 282:F179-90.

357. Lee T, Sumpio BE. Cell signalling in vascular cells exposed to cyclic strain: the emerging role of protein phosphatases. Biotechnol Appl Biochem 2004; 39:129-39.

358. Shyy JY, Chien S. Role of integrins in cellular responses to mechanical stress and adhesion. Curr Opin Cell Biol 1997; 9:707-13.

359. Berk BC, Corson MA, Peterson TE, Tseng H. Protein kinases as mediators of fluid shear stress stimulated signal transduction in endothelial cells: a hypothesis for cal- 
cium-dependent and calcium-independent events activated by flow. J Biomech 1995; 28:1439-50.

360. Berk BC, Min W, Yan C, Surapisitchat J, Liu Y, Hoefen R. Atheroprotective mechanisms activated by fluid shear stress in endothelial cells. Drug News Perspect 2002; 15:133-39.

361. Jalali S, del Pozo MA, Chen K, Miao H, Li Y, Schwartz MA, Shyy JY, Chien S. Integrin-mediated mechanotransduction requires its dynamic interaction with specific extracellular matrix (ECM) ligands. Proc Natl Acad Sci USA 2001; 98: 1042-6.

362. Stamatas GN, McIntire LV. Rapid flow-induced responses in endothelial cells. Biotechnol Prog 2001; 17:383-402.

363. Iba T, Sumpio BE. Morphological response of human endothelial cells subjected to cyclic strain in vitro. Microvasc Res 1991; 42:245-54.

364. Millward-Sadler SJ, Salter DM. Integrin-dependent signal cascades in chondrocyte mechanotransduction. Ann Biomed Eng 2004; 32:435-46.

365. Bell GI. Models for the specific adhesion of cells to cells. Science 1978; 200:61827.

366. Asthagiri AR, Lauffenburger DA. Bioengineering models of cell signaling. Annu Rev Biomed Eng 2000; 2:31-53.

367. Davies PF, Zilberberg J, Helmke BP. Spatial microstimuli in endothelial mechanosignaling. Circ Res 2003; 92:359-70.

368. Helmke BP, Davies PF. The cytoskeleton under external fluid mechanical forces: hemodynamic forces acting on the endothelium. Ann Biomed Eng 2002; 30:284-96.

369. Davies PF, Barbee KA, Volin MV, Robotewskyj A, Chen J, Joseph L, Griem ML, Wernick MN, Jacobs E, Polacek DC, dePaola N, Barakat AI. Spatial relationships in early signaling events of flow-mediated endothelial mechanotransduction. Annu Rev Physiol 1997; 59:527-49.

370. Chaplain MA. Mathematical modelling of angiogenesis. J Neurooncol 2000; 50: 37-51.

371. Plank MJ, Sleeman BD. A reinforced random walk model of tumour angiogenesis and anti-angiogenic strategies. Math Med Biol 2003; 20:135-81.

372. Breward CJ, Byrne HM, Lewis CE. A multiphase model describing vascular tumour growth. Bull Math Biol 2003; 65:609-40.

373. Alarcon T, Byrne HM, Maini PK. A cellular automaton model for tumour growth in inhomogeneous environment. J Theor Biol 2003; 225:257-74.

374. McDougall SR, Anderson AR, Chaplain MA, Sherratt JA. Mathematical modelling of flow through vascular networks: implications for tumour-induced angiogenesis and chemotherapy strategies. Bull Math Biol 2002; 64:673-702.

375. Levine HA, Pamuk S, Sleeman BD, Nilsen-Hamilton M. Mathematical modeling of capillary formation and development in tumor angiogenesis: penetration into the stroma. Bull Math Biol 2001; 63:801-63.

376. Holmes MJ, Sleeman BD. A mathematical model of tumour angiogenesis incorporating cellular traction and viscoelastic effects. J Theor Biol 2000; 202:95-112. 
377. Anderson AR, Chaplain MA. Continuous and discrete mathematical models of tumor-induced angiogenesis. Bull Math Biol 1998; 60:857-99.

378. Orme ME, Chaplain MA. A mathematical model of the first steps of tumour-related angiogenesis: capillary sprout formation and secondary branching. IMA J Math Appl Med Biol 1996; 13:73-98.

379. Chaplain MA, Anderson AR. Mathematical modelling, simulation and prediction of tumour-induced angiogenesis. Invas Metast 1996; 16:222-34.

380. Chaplain MA. The mathematical modelling of tumour angiogenesis and invasion. Acta Biotheor 1995; 43:387-402.

381. Byrne HM, Chaplain MA. Mathematical models for tumour angiogenesis: numerical simulations and nonlinear wave solutions. Bull Math Biol 1995; 57:461-86.

382. Chaplain MA, Stuart AM. A model mechanism for the chemotactic response of endothelial cells to tumour angiogenesis factor. IMA J Math Appl Med Biol 1993; 10:149-68.

383. Balding D, McElwain DL. A mathematical model of tumour-induced capillary growth. J Theor Biol 1985; 114:53-73.

384. Liotta LA, Saidel GM, Kleinerman J. Diffusion model of tumor vascularization and growth. Bull Math Biol 1977; 39:117-28.

385. Gaffney EA, Pugh K, Maini PK, Arnold F. Investigating a simple model of cutaneous wound healing angiogenesis. J Math Biol 2002; 45:337-74.

386. Pries AR, Reglin B, Secomb TW. Structural adaptation of microvascular networks: functional roles of adaptive responses. Am J Physiol Heart Circ Physiol 2001; 281: H1015-25.

387. Mantzaris NV, Webb S, Othmer HG. Mathematical modeling of tumor-induced angiogenesis. J Math Biol 2004; 49:111-87.

388. Zawicki DF, Jain RK, Schmid-Schoenbein GW, Chien S. Dynamics of neovascularization in normal tissue. Microvasc Res 1981; 21:27-47.

389. Tong S, Yuan F. Numerical simulations of angiogenesis in the cornea. Microvasc Res 2001; 61:14-27.

390. Ermentrout GB, Edelstein-Keshet L. Cellular automata approaches to biological modeling. J Theor Biol 1993; 160:97-133.

391. Bell AD. The simulation of branching patterns in modular organisms. Phil Trans Royal Society London, Ser B 1986; B313:143-59.

392. Duchting W, Ulmer W, Ginsberg T. Cancer: a challenge for control theory and computer modelling. Eur J Cancer 1996; 32A:1283-92.

393. Kiani MF, Hudetz AG. Computer simulation of growth of anastomosing microvascular networks. J Theor Biol 1991; 150:547-60.

394. Landini G, Misson G. Simulation of corneal neovascularization by inverted diffusion limited aggregation. Invest Ophthalmol Vis Sci 1993; 34:1872-5.

395. Indermitte C, Liebling M, Clemencon H. Culture analysis and external interaction models of mycelial growth. Bull Math Biol 1994; 56:633-64.

396. Markus M, Bohm D, Schmick M. Simulation of vessel morphogenesis using cellular automata. Math Biosci 1999; 156:191-206. 
397. Stokes CL, Lauffenburger DA. Analysis of the roles of microvessel endothelial cell random motility and chemotaxis in angiogenesis. J Theor Biol 1991; 152:377-403.

398. Turner S, Sherratt JA. Intercellular adhesion and cancer invasion: a discrete simulation using the extended Potts model. J Theor Biol 2002; 216:85-100.

399. Godde R, Kurz H. Structural and biophysical simulation of angiogenesis and vascular remodeling. Dev Dyn 2001; 220:387-401.

400. Othmer HG, Stevens A. Aggregation, blowup and collapse: the ABCs of taxis in reinforced random wals. SIAM J Appl Math 1997; 57:1044-81.

401. Levine HA, Sleeman BD, Nilsen-Hamilton M. Mathematical modeling of the onset of capillary formation initiating angiogenesis. J Math Biol 2001; 42:195-238.

402. Arakelyan L, Vainstein V, Agur Z. A computer algorithm describing the process of vessel formation and maturation, and its use for predicting the effects of antiangiogenic and anti-maturation therapy on vascular tumor growth. Angiogenesis 2002; 5:203-14.

403. Levine HA, Sleeman BD, Nilsen-Hamilton M. A mathematical model for the roles of pericytes and macrophages in the initiation of angiogenesis. I. The role of protease inhibitors in preventing angiogenesis. Math Biosci 2000; 168:77-115.

404. Pamuk S. Steady-state analysis of a mathematical model for capillary network formation in the absence of tumor source. Math Biosci 2004; 189:21-38.

405. Rolland Y,Bezy-Wendling J,Duvauferrier R, Bruno A. Modeling of the parenchymous vascularization and perfusion. Invest Radiol 1999; 34:171-5.

406. Sandau K, Kurz H. Modelling of vascular growth processes: a stochastic biophysical approach to embryonic angiogenesis. J Microsc 1994; 175(Pt 3):205-13.

407. Nekka F, Kyriacos S, Kerrigan C, Cartilier L. A model of growing vascular structures. Bull Math Biol 1996; 58:409-24.

408. Manoussaki D, Lubkin SR, Vernon RB, Murray JD. A mechanical model for the formation of vascular networks in vitro. Acta Biotheor 1996; 44:271-82.

409. Tranqui L, Tracqui P. Mechanical signalling and angiogenesis. The integration of cellextracellular matrix couplings. CR Acad Sci III 2000; 323:31-47.

410. Murray JD, Oster GF. Cell traction models for generating pattern and form in morphogenesis. J Math Biol 1984; 19:265-79.

411. Spencer A. Continuum Mechanics New York: Longman, 1980.

412. Ateshian GA, Warden WH, Kim JJ, Grelsamer RP, Mow VC. Finite deformation biphasic material properties of bovine articular cartilage from confined compression experiments. J Biomech 1997; 30:1157-64.

413. Holmes MH, Mow VC. The nonlinear characteristics of soft gels and hydrated connective tissues in ultrafiltration. J Biomech 1990; 23:1145-56.

414. Mow VC, Kuei SC, Lai WM, Armstrong CG. Biphasic creep and stress relaxation of articular cartilage: theory and experiments. J Biomech Eng 1980; 102:73-84.

415. Ferrara N, Henzel WJ.Pituitary follicular cells secrete a novel heparin-binding growth factor specific for vascular endothelial cells. Biochem Biophys Res Commun 1989; 161:851-8.

416. Gospodarowicz D, Abraham JA, SchillingJ. Isolation and characterization of a vascular 
endothelial cell mitogen produced by pituitary-derived folliculo stellate cells. Proc Natl Acad Sci USA 1989; 86:7311-5.

417. Lobb RR, Alderman EM, Fett JW. Induction of angiogenesis by bovine brain derived class 1 heparin-binding growth factor. Biochemistry 1985; 24:4969-73.

418. Muller G, Behrens J, Nussbaumer U, Bohlen P, Birchmeier W. Inhibitory action of transforming growth factor beta on endothelial cells. Proc Natl Acad Sci USA 1987; 84:5600-4.

419. Leavesley DI, Schwartz MA, Rosenfeld M, Cheresh DA. Integrin beta 1- and beta 3-mediated endothelial cell migration is triggered through distinct signaling mechanisms. J Cell Biol 1993; 121:163-70.

420. Swerlick RA, Brown EJ, Xu Y, Lee KH, Manos S, Lawley TJ. Expression and modulation of the vitronectin receptor on human dermal microvascular endothelial cells. J Invest Dermatol 1992; 99:715-22.

421. Senger DR, Ledbetter SR, Claffey KP, Papadopoulos-Sergiou A, Peruzzi CA, Detmar M. Stimulation of endothelial cell migration by vascular permeability factor/vascular endothelial growth factor through cooperative mechanisms involving the alphavbeta3 integrin, osteopontin, and thrombin. Am J Pathol 1996; 149:293-305.

422. Matsuda T, Kurumatani H. Surface induced in vitro angiogenesis: surface property is a determinant of angiogenesis. ASAIO Trans 1990; 36:M565-8.

423. Cullen JP, Sayeed S, Sawai RS, Theodorakis NG, Cahill PA, Sitzmann JV, Redmond EM. Pulsatile flow-induced angiogenesis: role of G(i) subunits. Arterioscler Thromb Vasc Biol 2002; 22:1610-6.

424. Davies PF, Tripathi SC. Mechanical stress mechanisms and the cell. An endothelial paradigm. Circ Res 1993; 72:239-45. 